\title{
Ostracod faunas in the Purbeck and Wealden of England
}

\author{
F. W. ANDERSON $\dagger$
}

\begin{abstract}
The occurrence and abundance of ostracods found in 98 subdivisions (Faunicycles) of late Jurassic to early Cretaceous age in the English Purbeck and Wealden are summarised. Most of the taxa found are illustrated from holotype or other material and details of their ranges and abundance given in relation to each faunicycle. The characters of the ostracod assemblages and zones are described. Three new species (Cypridea brendae, $C$. hispida and Eoparacypris edmundsi); also two new subspecies (Cypridea setina pelota and C. tuberculata dorsiclavala) are described and figured. A lectotype for Palaeocytheridea pellucida is selected and figured.
\end{abstract}

\section{PREFACE}

The late Dr. F. W. Anderson's geological career was particularly notable for his application of the study of ostracods to the stratigraphy and environmental history of the Purbeck and Wealden Beds of south-east England. This paper incorporates Dr. Anderson's latest views on Purbeck-Wealden faunicycles, records the distribution of the ostracod species and illustrates them with SEM photographs, many for the first time.

It seemed desirable to publish this major contribution as far as possible as Dr. Anderson compiled it a number of years ago. The stratigraphic terminology has, therefore, been left as he used it so that it is consistent with his other papers and reports and in unpublished charts and diagrams.

Dr. W. A. Read explains "that the chief problems arise in the nomenclature of the Ashdown Beds and strata formerly assigned to the 'Upper Purbeck'. Dr. Anderson used the terms 'Ashdown Sand' (for the upper arenaceous division) and both 'Fairlight Clays' and 'Upper Purbeck' for a lower argillaceous division. These are not used in current Geological Survey publications as it is considered an impracticable lithostratigraphic division; the Fairlight Clays are regarded as a recurring facies within the broad spectrum of fluvial environments in which the Ashdown Beds were laid down. The Purbeck succession in the Sussex inliers and adjacent boreholes has been revised by Lake \& Holliday (1978) and Morter (1984) who now take the base of the Wealden at the top of the Greys Limestones. Anderson (in Anderson \& Bazley, 1971) referred the Greys Limestones to the Middle Purbeck and the shales and clays above to the Upper Purbeck. The latter are currently referred to the 'Ashdown Beds Formation' comprising the beds from the top of the Greys Limestones to the base of the Wadhurst Clay. The beds labelled Fairlight Clays and Upper Purbeck mudstones and silts in Dr.

\footnotetext{
†See Preface.
}

Anderson's figures form the lower part of this formation and of the Fairlight division as used informally by Morter (1984); those labelled Ashdown Sand form the Ashdown Sand division (Morter, 1984); both are variable lithologically and are not considered formal, laterally persisent lithostratigraphic units."

Dr. R. H. Bate comments "This paper summarises the outstanding contribution made by the late $F$. W. Anderson to modern ostracod research, particularly the recognition of the importance of ostracods in biostratigraphy. His interpretation of the salinity tolerance of some ostracods in the Purbeck-Wealden is, however, at variance with that of other ostracod workers especially for the genusDarwinula - presently found living in freshwater. If this environment was also occupied by this taxa at that time, there would be a change of emphasis from the 'S' phase to the ' $C$ ' phase for the genus."

The work was nearly completed at the time of Dr. Anderson's death in 1982. The manuscript was further prepared for the press by Dr. H. C. Ivimey-Cook of the British Geological Survey (B.G.S.) and is published with the approval of the Director, B. G. S. (N.E.R.C.). Communications regarding it should be addressed to the Biostratigraphy Research Group, B.G.S. Keyworth, Nottingham NG12 5GG. The B.G.S. holds many of Dr. Anderson's original diagrams and notes, as well as range charts which are too large and complex to be published, (see Appendix herein).

On his behalf we would also like to acknowledge the skill of Mrs. B. E. Coleman who took most of the photographs of these ostracods on a Cambridge Model 2A Stereoscan. Some extra photographs were taken by Mr. I. P. Wilkinson and Dr. J. Whittaker (B.M.(N.H.)) to complete the plates.

In view of the size and format, the Editor has allowed some departure from the usual instructions to authors in its presentation.

The cost of publication has been partly covered by the receipt of a grant from the British Geological Survey. 


\section{INTRODUCTION}

The Purbeck and Wealden beds in England span the Jurassic to Cretaceous boundary and present a range of sedimentary environments from hypersaline through varying degrees of salinity to virtually freshwater. The sediments range from clays, often sphaerosideritic, through mudstones, limestones and siltstones to coarse, commonly fluvial sandstones (Allen, 1976; 1981).

Geographically, two distinct areas can be recognised (Fig. 1). To the east, a steadily subsiding basin occupied what is now the Weald of Sussex and Kent and part of east Hampshire; to the west, a lagoon covered west Hampshire, Dorset, the Isle of Wight, and parts of Buckinghamshire, Berkshire and Wiltshire. Everywhere the water remained shallow, and particularly in the Wealden, plant beds with lignite are common. The fauna includes bivalves, gastropods, foraminifera, ostracods, fish, reptiles and primitive mammals.
The most abundant and widely distributed fossils are ostracods which afford the most suitable material for stratigraphical correlation. Under the stress of a shallow water environment varying in salinity, they produced a large number of species and varieties, some of which had a limited salinity tolerance with consequent variation in their numbers in any particular assemblage. Thus, there developed what the writer has referred to as Faunicycles, i.e. an alternation of ostracod faunas with a high salinity tolerance with those having a preference for fresher water. Several faunicycles are found within each characteristic faunal assemblage (Figs. 2 and 3 ) and these allow much closer stratigraphical correlation than is possible using the faunal assemblage or zonal distribution alone. This is important in view of the difficulty of lithological comparison in such a varied sequence of sediments.

The earliest zonal division of the Purbeck beds by means of the ostracod faunas was that of Lyell (1855)

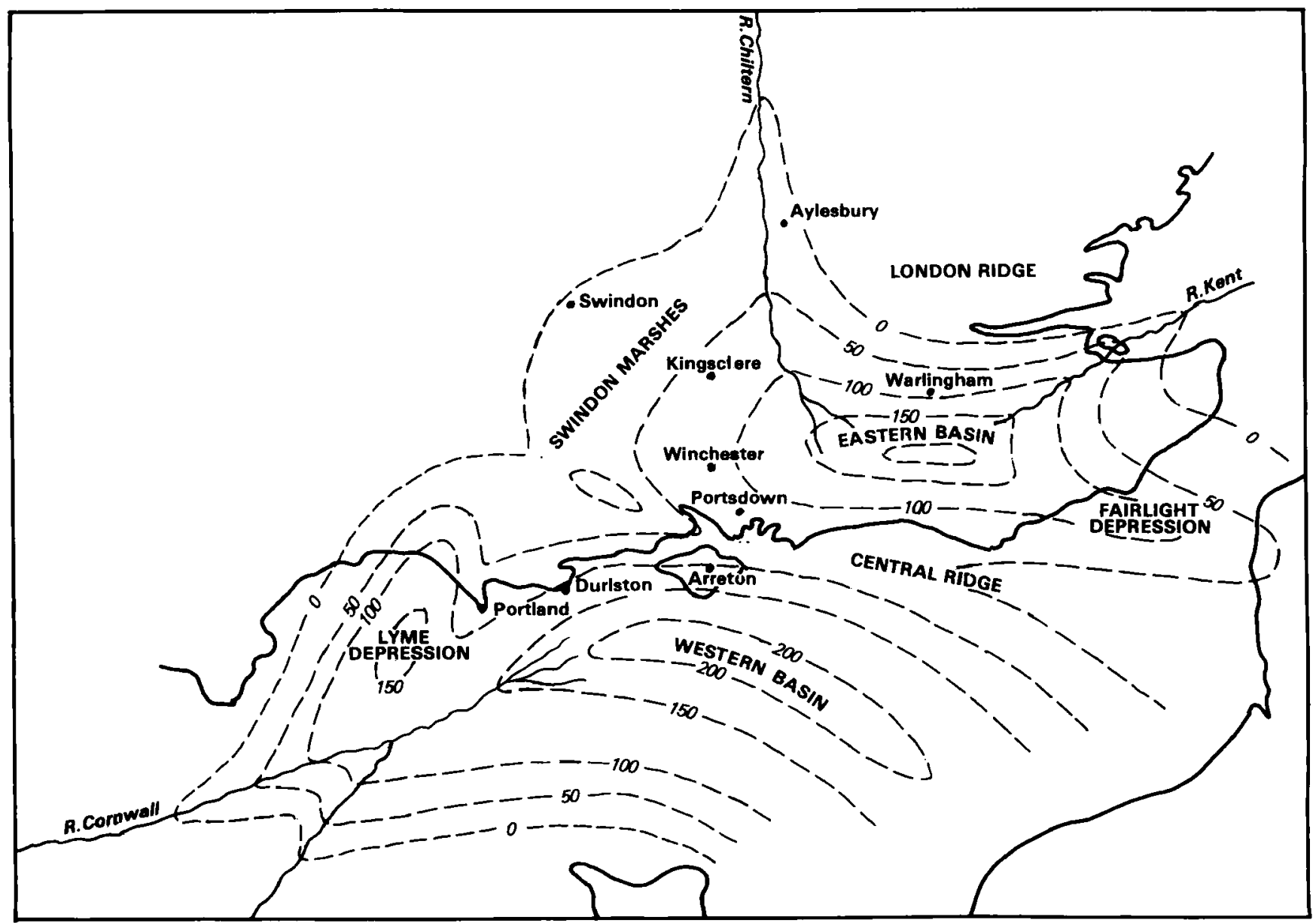

Fig. 1. Sketch map of the palaeogeography of the Purbeck with schematic isopachytes at $50 \mathrm{~m}$ intervals. A 'western basin', centred in the English Channel south of the Isle of Wight, received sediment dominantly from the west. A subsidiary depression was present in Lyme Bay. In the north, the 'River Chiltern' separated an area of shallows south-east of Swindon from the Aylesbury area and the southern edge of the London Platform. Sediment also accumulated in an eastern basin in the Weald of Sussex and Kent. This was separated from the western basin by the Central Ridge (Bognor Swell of Allen, 1976) which extended from the Vale of Wardour, across the Hampshire Basin north-east of the Isle of Wight and to the south of the South Downs. 
who utilised species described by Fitton (1836) and Forbes (1855). The systematic work of T. R. Jones between 1878 and 1888 , however, was a great step forward, and in 1885 Jones was able to list seven species from the Lower Purbeck, 13 from the Middle Purbeck and eight from the Upper Purbeck. Then followed a period of inactivity until the writer began work on the Dorset sections of the Purbeck beds in 1928, followed by Sylvester-Bradley (1941 b) in Dorset and Wiltshire, by W. Heap, an enthusiastic amateur geologist resident in Swanage, and by Barker (1966 a and b; 1975) in Dorset.

Knowledge of the succession of ostracod faunas, particularly in the Weald, has been greatly increased by boreholes put down during the search for coal in Kent (Lamplugh, Kitchin \& Pringle, 1923), for oil and gas in Hampshire and the Weald (Falcon \& Kent, 1960), for gypsum in Sussex (Howitt, 1964) and as part of the Geological Survey six-inch mapping and exploratory drilling programme in Surrey and Sussex. A list of some of the diagrams now deposited with B.G.S., giving additional details of some of these faunal sequences and their correlations is given in the Appendix to this paper.

\section{GENERAL STRATIGRAPHY PURBECK}

Except in marginal areas such as Swindon and Aylesbury, where there is an alternation between Purbeck and Portland-type sediments, the transition from one lithology to: the other is abrupt. After a relatively brief period at the beginning of the Purbeck, evaporitic environments prevailed in both the eastern and the western areas (Fig. 1) giving rise to beds of gypsum and/or anhydrite with mudstones and algal limestones (Fig. 2). Then followed a series of Lower Purbeck mudstones and limestones, the Adit and IceHouse limestones of the Weald (eastern basin) and the Cypris Freestones of Dorset, culminating in the Dunkshaws Limestone in the east and its equivalent, the Hard Cockle Limestone (part of the Hard Cockle Beds) in the west. Similar sedimentary conditions prevailed throughout the remainder of the Lower Purbeck Soft Cockle Beds, continuing up into the Middle Purbeck as the Marly Freshwater and Cherty Freshwater Beds of Dorset. This sequence was interrupted by a marine episode which produced thick shell beds throughout the area (the so-called Cinder Beds) which are locally rich in oysters in the Isle of Purbeck. Though the area appears to have been flooded with sea water, the Cinder Beds are not known to extend beyond the area of deposition of the underlying less marine sediments and they show no evidence of a general discontinuity at their base. Their characteristic ostracod, Galliaecytheridea postsinuata, had already appeared in small numbers below the Cinder Beds and is also present in the beds immediately above. Moreover, when conditions again became more brackish, the pre-Cinder Beds ostracod fauna was re- established with no major change. Probably this more saline episode, though dramatic, was of short duration in view of the relatively small amount of interstitial sediment binding the oyster shells. However, both in the east and west it took some time to revert entirely to earlier conditions, hence the term Intermarine Beds for the sediments that followed in Dorset. The next unit is the Scallop Limestone, part of the Scallop Beds of Dorset, followed by shales-with-'beef' (layers of fibrous calcite).

The base of the Upper Purbeck in Dorset is marked by the Upper Broken Shell Limestone which is succeeded by shales and limestones apparently laid down in fresher water and containing beds largely composed of Viviparus [Paludina] shells - the Purbeck Marbles.

\section{WEALDEN}

(a) Wessex (Hampshire, Dorset and adjoining areas)

The bulk of the Wealden of the western lagoon consists of sands and mottled clays which are poorly known at outcrop. They are generally unfossiliferous except near the base of the sequence, where early Wealden faunas have been found, and also at the top, where the Weald Shales of the Isle of Wight contain an ostracod assemblage comparable with that of the upper Weald Clay of the "Weald.

\section{(b) Weald (Surrey, Sussex and Kent) Hastings Beds}

Fairlight Clay and Ashdown Sand. The earliest Wealden sediments were essentially deposited as a continuation of the Upper Purbeck type sedimentation and there is no break in the ostracod faunas. The sediments consist of mudstones, shales, silts and sands.

Wadhurst Clay. Few Purbeck species of ostracods persist into this unit of some $60 \mathrm{~m}$ of mudstones, but the entry of many new species provides very characteristic faunas. The base of the Wadhurst Clay would in many ways be a suitable horizon at which to take the base of the Wealden.

Tunbridge Wells Sand, including Grinstead Clay. These sands and clays contain a similar ostracod fauna to the upper part of the Wadhurst Clay, but with fewer species.

Weald Clay. The lower part of the Weald Clay consists of a series of siltstones, including the Horsham Stone, with a fauna dominated by Cypridea dorsispinata. The overlying clays, about $60 \mathrm{~m}$ thick, contain a rich, varied and distinctive ostracod fauna referred to as the Henfield phase. In Anderson (1967), the terms Horsham Group and Henfield Group were used for two ostracod assemblages in the Lower Weald Clay, but in view of the lithological connotation now attributed to the word 'Group', 


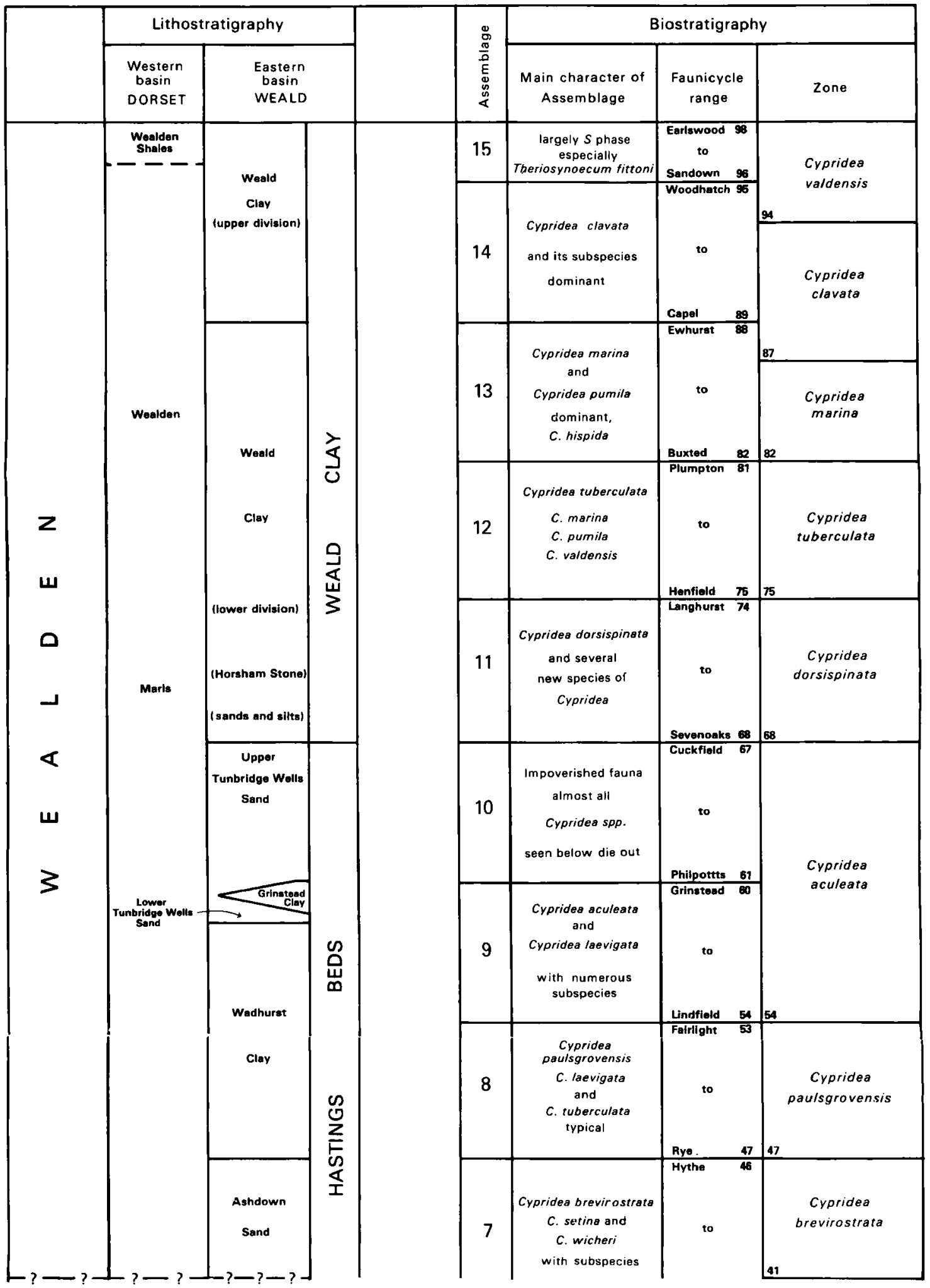

Fig. 2. 
Ostracod faunas in the Purbeck \& Wealden of England

Fig. 2 . . contd.

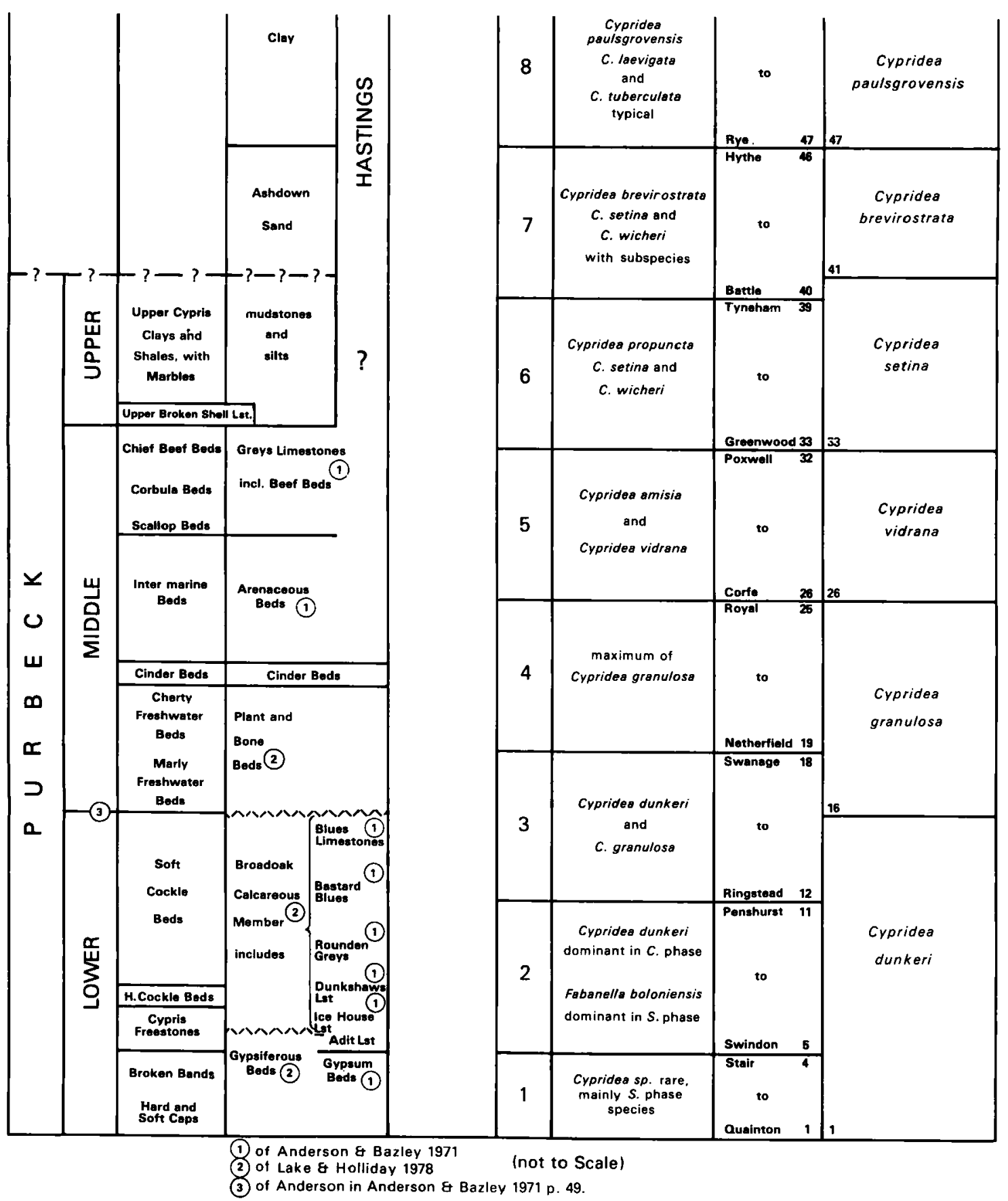

Fig. 2. Generalised lithological and biostratigraphical sequences in the Purbeck and Wealden of southern England. 
these are here re-named as a 'phase'. Above the Henfield phase (Figs. 5 and 6) are $300 \mathrm{~m}+$ of sandstones, silts and clays with occasional thin 'Paludina' limestones (Sussex Marble).

In Fig. 6, the sequences in the central Weald are compared with those towards the northern and southern margins. Parts of the sequences are shown in greater detail to clarify the variations in the lithological and faunicycle successions. In the south-east, the clays are frequently sideritic and there is a lack of coarse sediment near the southern margin. Fig. 6 also shows that the preserved thickness of sediment representing a faunicycle may be very variable.

\section{THE FAUNICYCLE}

The sequence of ostracod faunas in Purbeck and Wealden strata shows that there is repeated alternation between faunas dominated by species of Cypridea (the C-phase) and those by species belonging to genera other than Cypridea, some of which clearly have a more saline provenance (the S-phase). These two phases appear to be antipathetic, from which it is assumed that salinity was an important factor in determining their composition. Thus, the S-phases are believed to represent periods of higher salinity, perhaps resulting from reduced rainfall, but in the Purbeck and Wealden, these probably never reaching true marine conditions. Conversely, the less saline waters of the $\mathbf{C}$-phase were probably never completely fresh. The combination of an $\mathbf{S}$-phase with the succeeding $\mathbf{C}$-phase fauna represents a Faunicycle, 98 of which have so far been recognised (Figs. 3 and 4). Faunicycles form a basis for correlation throughout the Purbeck and Wealden of southern England which is more detailed than is possible by other means. There are, however, some complications. For example, where it has been possible to study a Faunicycle in detail - in a uniform lithology and at close intervals (see Anderson \& Bazley, 1971, figs. 6 and 7) it is evident that the transition from the $S$-phase to the C-phase assemblages is anything but uniform, consisting rather of a series of minor rhythms. Furthermore, the salinity tolerance of S-phase genera varied greatly, from those like Macrodentina that clearly favoured a more saline environment, to the darwinulids that are generally most abundant in the middle range of a Faunicycle. In the Purbeck especially, extreme lithological variation affected the sequence of faunal changes. There are 'Dirt Beds', probably fossil soils, representing near terrestrial conditions; evaporites, generally beds of gypsum or anhydrite; and layers of 'beef' (fibrous calcite' - probably resulting from penecontemporaneous pre-consolidation crystallisation.

In general, however, there appears to have been a trend from the more saline waters of the Lower Purbeck, where the $\mathbf{C}$-phase species in a faunicycle may represent only a small percentage of the total fauna, to the Upper Purbeck and Wealden, where they generally account for at least $50 \%$. This change is briefly interrupted at times by a return to more saline conditions as in the Cinder Beds Faunicycle of the Purbeck (97\% S-phase species) and in the Henfield Faunicycle of the Weald Clay (80\% S-phase species).

\section{SALINITY}

Since the concept of a Faunicycle is based on the assumption that some, if not all, ostracods exhibit a salinity preference, it is essential to attempt some kind of estimate as to what this salinity range is. For the PurbeckWealden faunas, this has proved particularly difficult although Morter (1984) has suggested salinity ranges for certain bivalves and gastropods. It is easy to demonstrate by association that some genera occurred in more saline water than others, but to establish the degree of salinity is another matter. An arbitrary grouping, therefore, has been adopted according to which all the species of the genus Cypridea are classed as $\mathbf{C}$-phase forms (i.e. nearer to freshwater), and the species of all other genera as S-phase forms which are assumed to indicate marine or brackish-water conditions.

It was at one time thought that the Purbeck-Wealden deposits were laid down in a predominantly freshwater environment and therefore that the non-terrestial fauna, including the ostracods, was freshwater and presumably lacustrine. These deposits, however, contain a variety of taxa some of which may indicate proximity to land but not necessarily preservation in freshwater deposits (e.g. mammal, crocodile, turtle and dinosaur remains, the insect and isopod beds and the occurrence of gastropods such as Physa, Valvata and Viviparus [Paludina]). There are also fossil soils. On the other hand, there are fish, including sharks, marine gastropods (Procerithium (Rhabdocolpus) and Promathildia) and bivalves (Grammatodon, 'Mesosacella' [Nuculana], Modiolus, Myrene, Myophorella, 'Pecten', Pinna, Protocardia and Venilicardia), the echinoid Hemicidaris and some foraminifera of more marine aspect. Taxa such as Liostrea, Neomiodon, Cassiope and Hydrobia may be more tolerant of salinity fluctuations.

Ostracods are the most abundant fossils in the Purbeck and Wealden and are found in association with all these other forms. It could be expected, therefore, that some at least were marine, and some belong to genera already established earlier in the Jurassic. From the Fyledal Clay (Kimmeridgian-Portlandian) Christensen (1968) listed Rhinocypris (Ilyocypris), Klieana, Macrodentina, Eocytheropteron, Fabanella, Galliaecytheridea and Dicrorygma (Stenestroemia). Barker (1966 a) found Procytheropteron, Macrodentina, Paraschuleridea, Protocythere, Orthonotacythere and Galliaecytheridea 
in the Portlandian. Bate $\dagger$ (1965) recorded Darwinula, Limnocythere, Bisulcocypris, Theriosynoecum and Timiriasevia from the Bathonian of Oxfordshire and he regarded these as freshwater forms despite their association with a marine fauna.

The determination of $\delta^{13} \mathrm{C}$ ratios by Allen \& Keith (1965), though as yet inconclusive, supported the suggestion that some at least of the Purbeck-Wealden ostracods were marine forms. Samples (of calcitic shells and some limestones) which gave a $\delta^{13} \mathrm{C}$ value of -2 or more and are therefore thought to be marine may also contain ostracods such as Macrodentina, Procytheropteron, Galliaecytheridea, Eoparacypris, Bisulcocypris, Scabriculocypris, Timiriasevia and Rhinocypris.

Association with marine genera in earlier parts of the Jurassic does not necessarily mean that PurbeckWealden ostracod genera were marine, but neither does an association in the Tertiary with freshwater forms indicate the contrary. If such genera as Fabanella, Mantelliana and Theriosynoecum were freshwater, they must have been either fluviatile or lacustrine. If they were freshwater, this should be indicated by their geographical distribution (i.e. they should be more abundant at or near the effluents), but this has not been established. Fabanella is abundant in the Lower Purbeck, and Theriosynoecum in the Upper Weald Clay in all areas examined, not only in certain marginal areas. If lacustrine, they should be associated with freshwater molluscs such as Unio. Instead, the association is with Corbula and Liostrea.
Eoparacypris, Fabanella, Galliaecytheridea, Macrodentina, Orthonotacythere, Paraschuleridea, Procytheropteron, Strenestroemia and Wolburgia are found in the Portlandian associated with Serpula, Isognomon, Liostrea, Myophorella, Protocardia and Aptyxiella. This type of assemblage, with the addition of rare specimens of Cypridea, dominates the basal beds of the Purbeck and continues upwards, especially in Faunicycles like the Hard Cockle, but with species of Cypridea becoming increasingly abundant. This faunal progression is interrupted by the Cinder Beds, where Galliaecytheridea is the dominant form and is accompanied by Myophorella, Protocardia, Isognomon, serpulids and the echinoid Hemicidaris.

Although the S-phases of faunicycles above the Cinder Beds still contain examples of such genera as Macrodentina and some Liostrea, they were relatively less important, and species of Cypridea became more abundant and varied. In the Wealden it is probable that S-phase brackish-water conditions occurred intermittently for example in the Wadhurst Clay, in the Henfield phase at the base of the Weald Clay and, in particular, near the top of the Weald Clay, where Fabanella reappears and Theriosynoecum is very abundant - possibly heralding the marine transgression of the Lower Greensand.

$\dagger$ Bate interpreted the freshwater ostracods as having been brought into a marine environment by rivers but they could also have been reworked and redeposited (Ed.).

Fig. 3. The stratigraphical distribution of the ostracod genus Cypridea in the Purbeck and Wealden of England. A succession of relatively short-lived species makes it possible to identify a series of typical assemblages. Such species as $C$. coelnothi, $C$. posticalis, $C$. arenosa and $C$. bogdenensis are particularly important indicators of horizon. Ranges of some important subspecies are given on Fig. 5.

Fig. 4. The stratigraphical distribution of the commoner ostracod genera, other than Cypridea, in the Purbeck and Wealden of England. Genera such as Damonella, Darwinula, Mantelliana, Fabanella and Theriosynoecum are represented throughout this period. Others such as Galliaecytheridea, Klieana and Orthonotacythere appear to be restricted to the more saline environments.

Fig. 5. The distribution of the species and subspecies of Cypridea upon which the main biostratigraphical subdivisions of the Purbeck and Wealden Beds are based. 


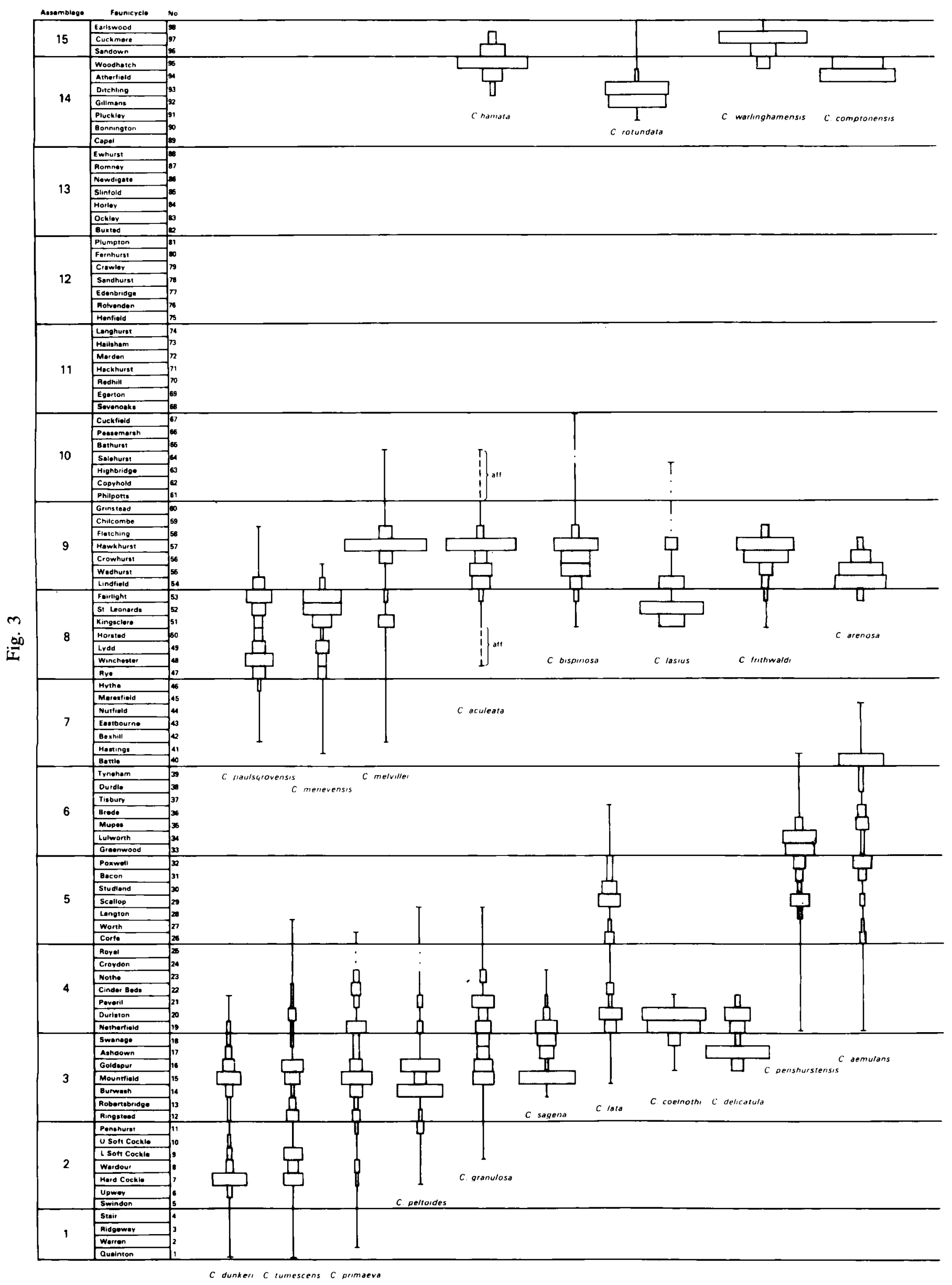




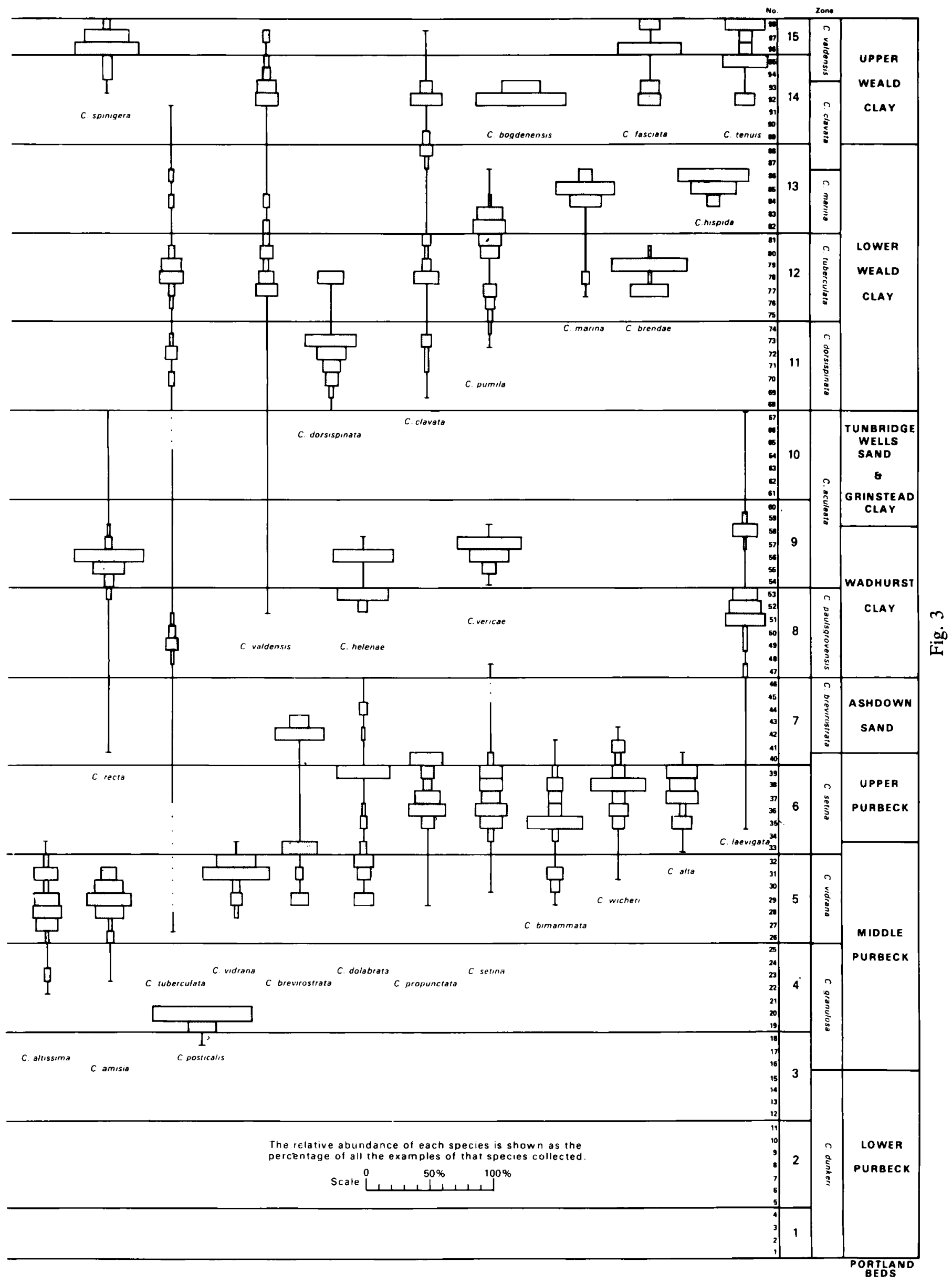




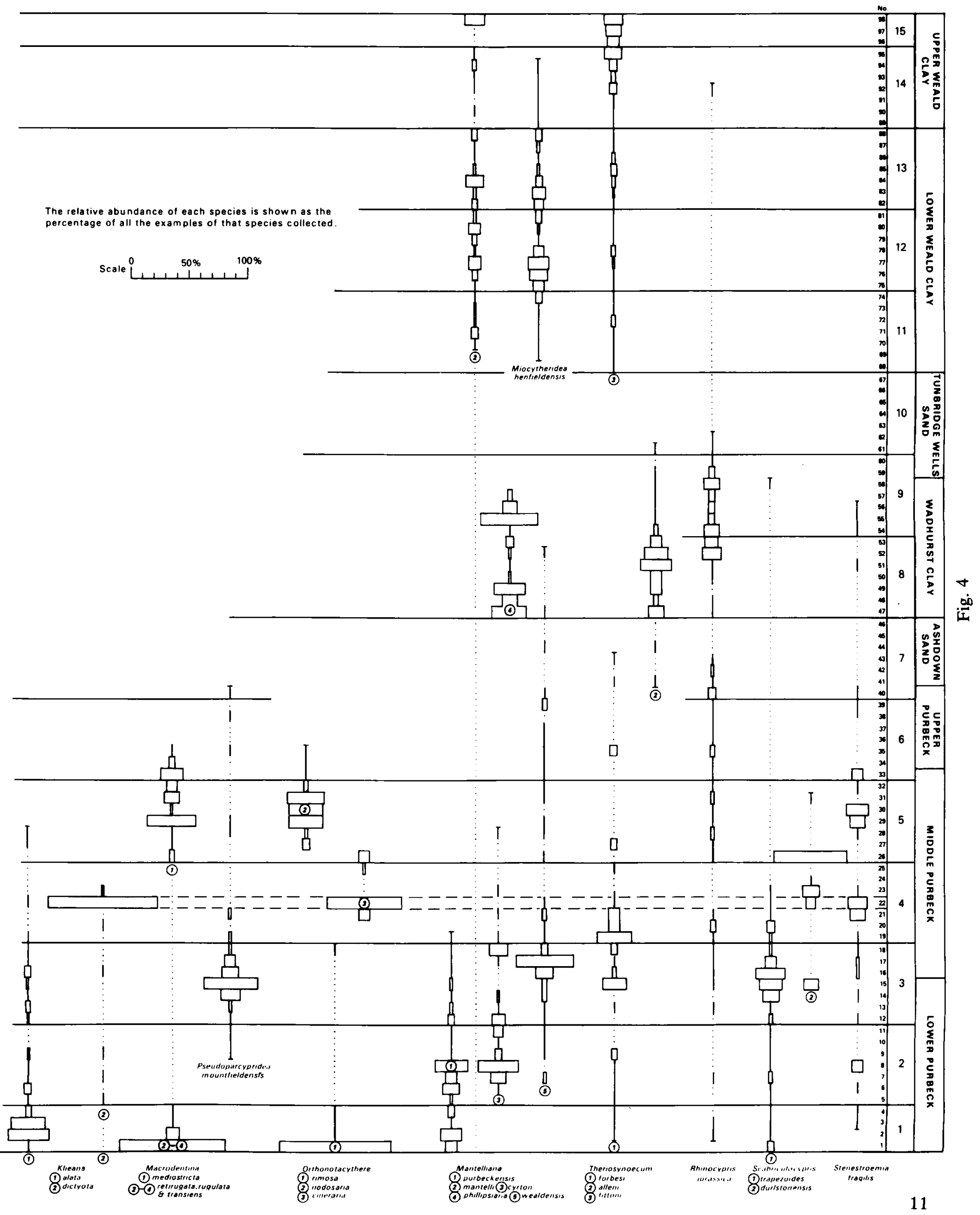


Anderson

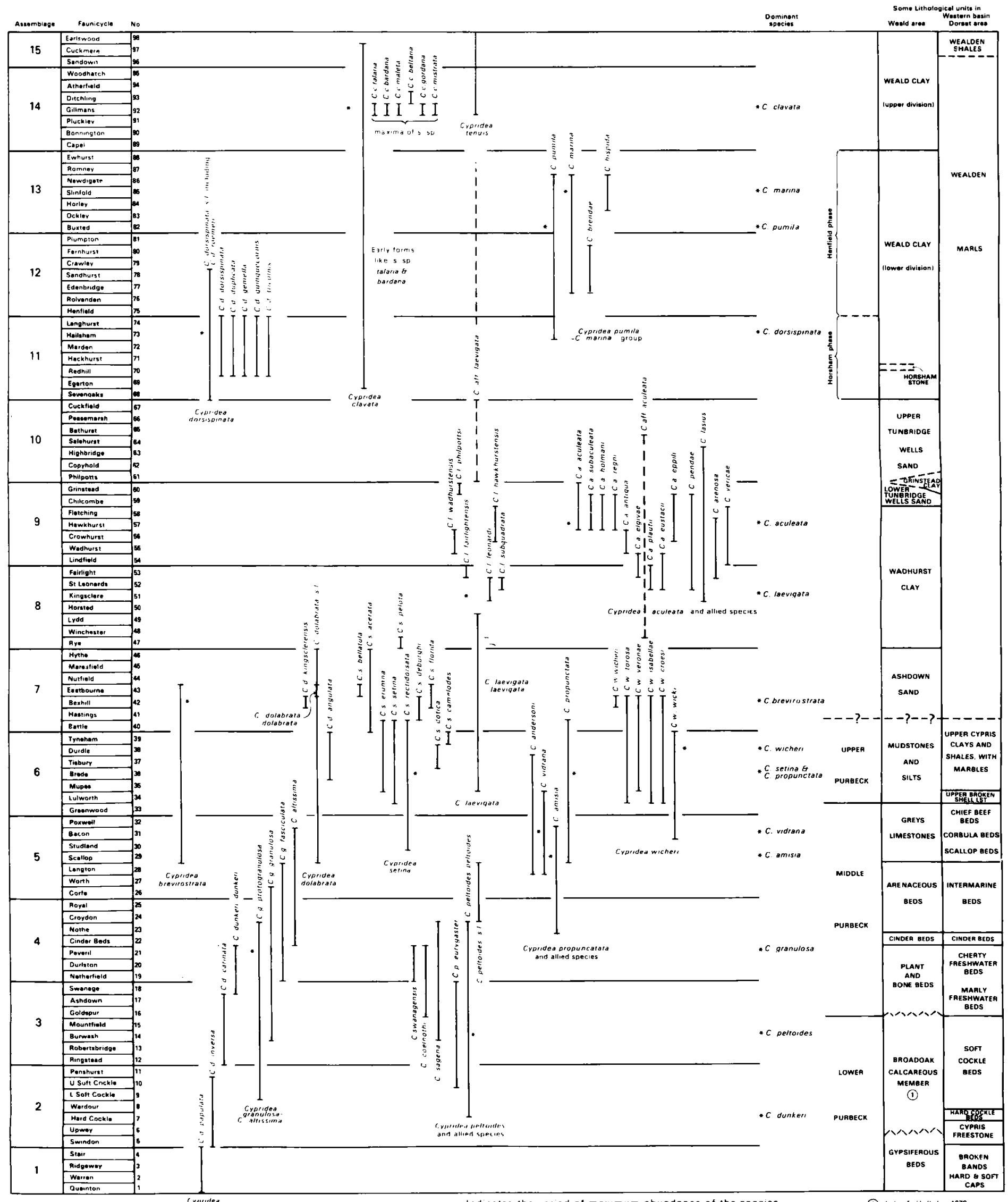

Fig. 5 


\section{FAUNAL ASSEMBLAGES}

The rate of evolution of the Purbeck-Wealden ostracods varied considerably. New forms of Cypridea were constantly appearing, whereas evolution in the S-phase genera was much slower and some species continued throughout, virtually unchanged. This appears to be generally the case with most animals and the production of new species can be correlated with stress conditions such as those associated with shallow water and rapidly changing environments. Changes in the composition of the ostracod faunas in the PurbeckWealden are superimposed on the variations due to salinity and sedimentary changes. Thus, the divisions determined by sedimentation, salinity and evolutionary changes coincide only rarely. There does, however, appear to have been some recognisable changes in the character of the assemblage about every seven faunicycles (see Figs. 3 and 4), so that the evolutionary rate of the genus Cypridea at least appears to have been constant.

Assemblage 1 includes species found also in the Upper Portland beds. This assemblage is followed by 13 others after which, in Assemblage 15, the approach to more saline conditions becomes evident. In Anderson (1973) the Purbeck-Wealden faunas were divided into 10 Assemblages, but as more evidence has become available, this is now considered to be inadequate and to be too much influenced by changes in sedimentation.

\section{SEQUENCE OF OSTRACOD FAUNAS}

Locality data are denoted by abbreviations that can be identified from the list on pages 38-40. To show the extent of the change in the ostracod faunas between the Portland Beds and Assemblage 1 of the Purbeck, the species with an asterisk $\left({ }^{*}\right)$ are those that continue into overlying beds and the species with a dagger $(\dagger)$ are first recorded in that unit. Where authors of species are not given in this section, they are given in "Notes on the Species" which also gives a reference to a figure in Plates 1-12 for species from the Purbeck and Wealden.

\section{Portland Beds}

Portland Sand (after Barker, 1966a, b); from FW. $\mathrm{HO}, \mathrm{Pq}, \mathrm{WW}$ :

Cytherelloidea paraweberi Oertli

${ }^{*}$ Eocytheridea eusarca Galliaecytheridea postrotunda Oertli

Galliaecytheridea wolburgi (Steghaus)

* Macrodentina retirugata

Macrodentina rudis Malz

*Macrodentina transiens (T. R. Jones)

${ }^{1}$ Orthonotacythere elongata Barker

${ }^{1 *}$ Orthonotacythere levis Barker

* Orthonotacythere rimosa

*Protocythere serpentina

'referred to Paranotacythere by Bassioni (1974).
Portland Stone (after Anderson 1941, SylvesterBradley 1941, Barker 1966a, b); from Bu, FW, HO, Pq, Sw, WW:

${ }^{*}$ Cypridea dunkeri

* Cypridea tumescens

${ }^{*}$ Eocytheridea eusarca

*Eoparacypris weedonensis

*Fabanella boloniensis

${ }^{*}$ Macrodentina retirugata

* Macrodentina rugulata

*Macrodentina transiens

Orthonotacythere levis

${ }^{*}$ Orthonotacythere rimosa

*Paraschuleridea buglensis Barker

*Protocythere serpentina

Procytheropteron bicosta Barker

Stenestroemia calyptroides Anderson

*Wolburgia visceralis

Wolburgia visceralis accounts for $35 \%$ of the specimens recovered, the three species of Macrodentina for $26 \%, P$. buglensis for $19 \%$ and $P$. serpentina for $19 \%$.

\section{Purbeck Beds}

In the following account, the number of ostracod specimens used to determine the fauna of each faunicycle is recorded so that the significance of the percentages quoted for the species within the fauna can be assessed. Poorly preserved material or ostracods of uncertain horizon are omitted. The latter represent almost half of the total specimens (about 400.000) recovered. Fig. 2 tabulates the main lithostratigraphical units and Assemblages 1-15, relating these also to the faunicycles and zones based in species of Cypridea. Figs. 3 and 4 show the ranges of species of Cypridea and other taxa of ostracods respectively. On both figures, the relative abundance of each species is shown as the percentage of all the examples of that species collected. i.e. it shows maxima-minima in the occurrence of species. Fig. 5 illustrates the inferred relationships of some of the species of Cypridea and also indicates the dominant species at various times and relates these to the lithostratigraphical units. Examples of the real thicknesses of these units are shown in Fig. 6.

\section{ASSEMBLAGE 1}

Represents the transition from Portland to Purbeck faunas. As seen at Swindon and in the Aylesbury area. S-phase genera such as Macrodentina and Wolburgia are gradually superceded by Fabanella and Mantelliana and this may indicate a reduction in salinity. Four faunicycles have been recognised:

Faunicycle 1, Quainton. 5485 specimens from $A y$ and Sw.

S-phase species represent $99 \%$ of the fauna:

Eocytheropteron eusarca

Eoparacypris weedonensis 
Fig. 6. Correlation of the Wealden Beds of the Weald.

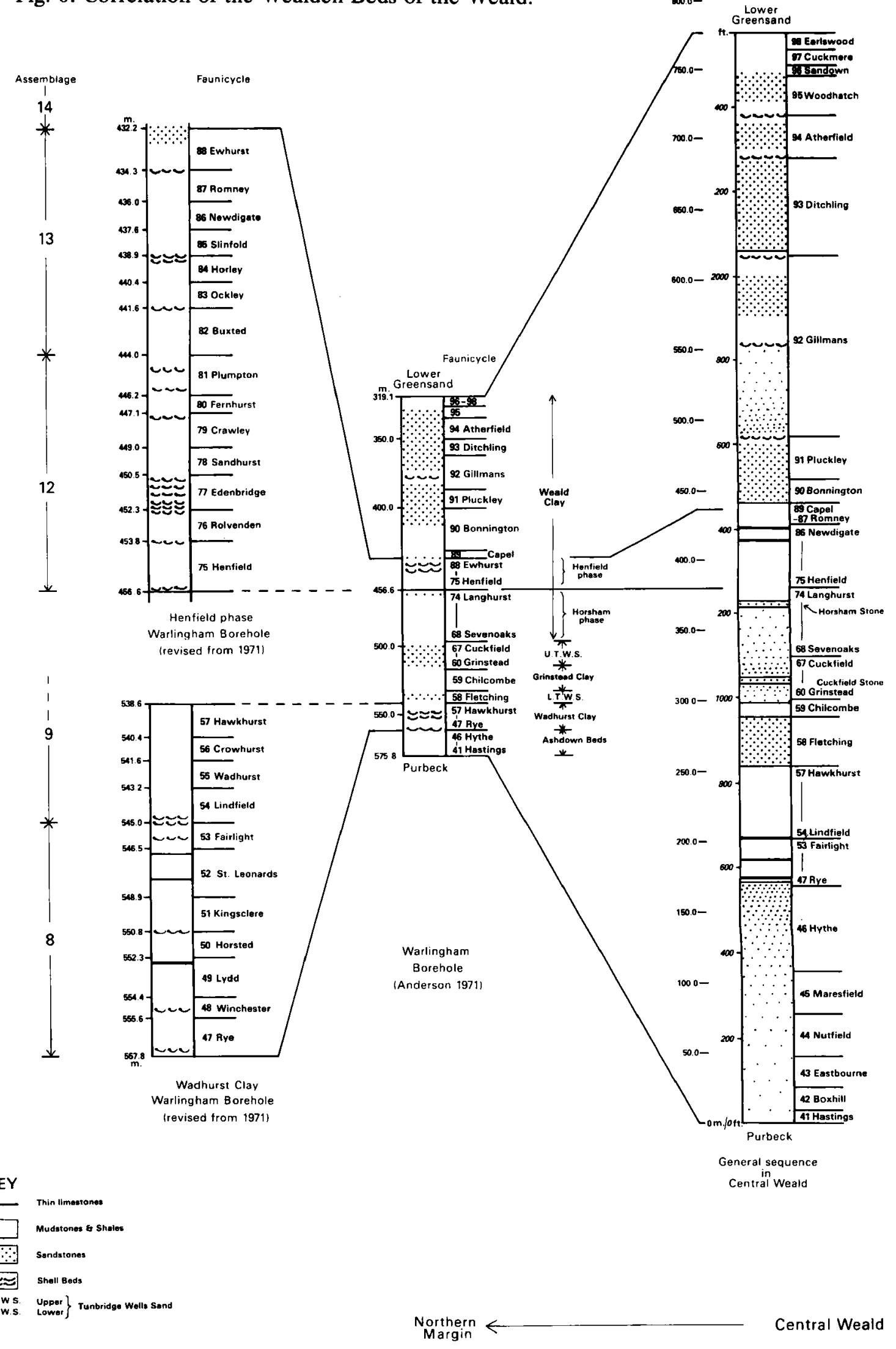


Ostracod faunas in the Purbeck \& Wealden of England

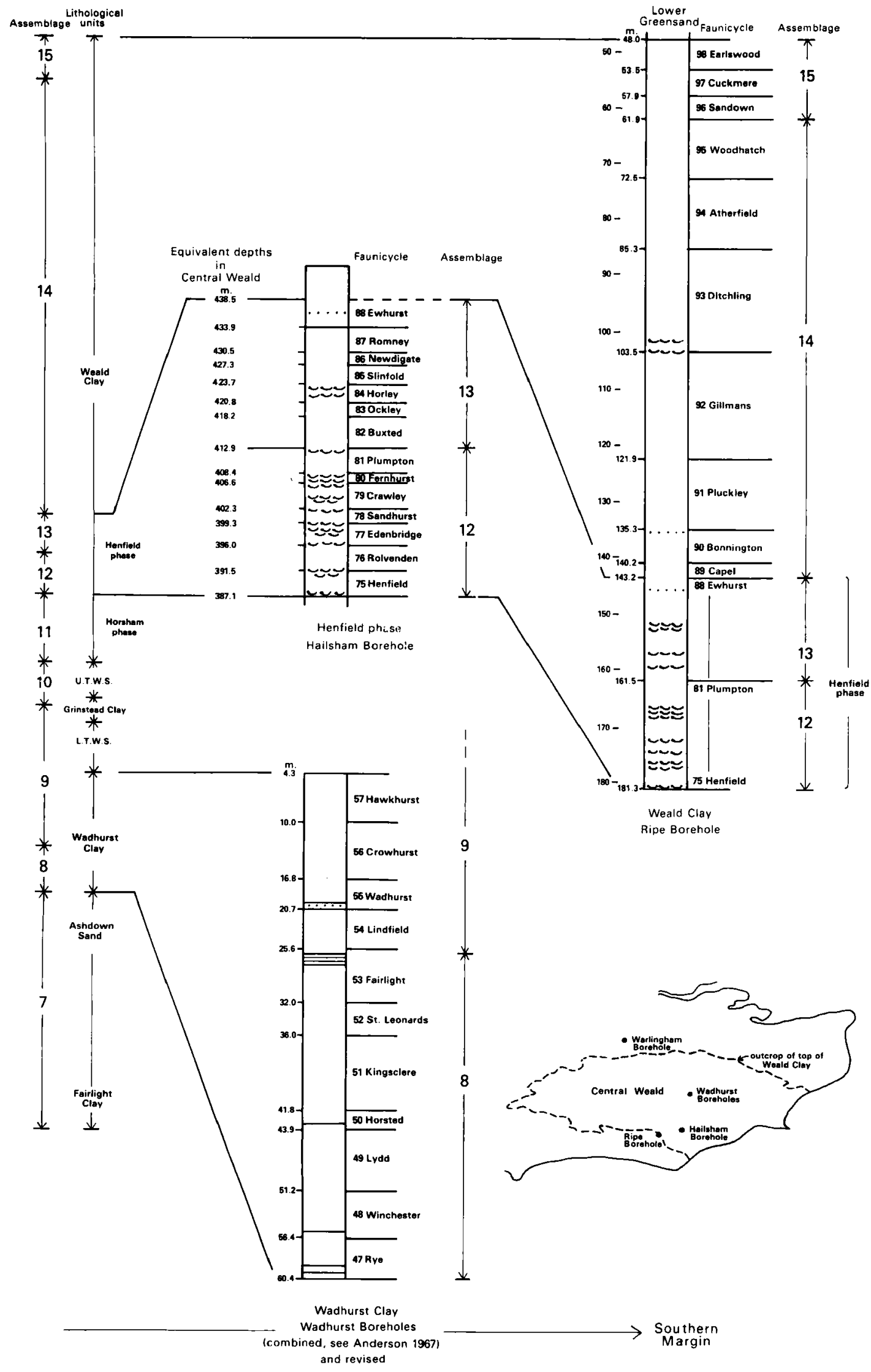


*Fabanella ansata

${ }^{*} F$. boloniensis

$23 \%$

${ }^{*}$ Klieana alata

${ }^{*}$ Macrodentina retirugata

${ }^{*} M$. rugulata

M. transiens

${ }^{*}$ Mantelliana purbeckensis

Orthonotacythere rimosa

*Paraschuleridea buglensis

*Protocythere serpentina

Procytheropteron barkeri

* Scabriculocypris acanthoides

* $S$. trapezoides

*Wolburgia visceralis

C-phase species represent less than $1 \%$ of this fauna:

${ }^{*}$ Cypridea dunkeri and ${ }^{*} C$. tumescens

This faunicycle does not appear to be represented other than in the marginal areas at Swindon and near Aylesbury.

Faunicycle 2, Warren. 2814 specimens from $\mathrm{Ay}, \mathrm{Pq}, \mathrm{Sw}$ and WN.

S-phase species represent $98 \%$ of the fauna:

$\dagger$ Damonella ellipsoidea

†D. pygmaea

$\dagger$ Darwinula leguminella

*Fabanella ansata , 67\%

${ }^{*} F$. boloniensis

* Klieana alata

Macrodentina retirugata

M. rugulata

${ }^{*}$ Mantelliana purbeckensis

${ }^{*}$ Paraschuleridea buglensis

*Protocythere serpentina

*Procytheropteron barkeri

$*$ * + hinocypris decipiens Anderson

$*+R$. jurassica

Scabriculocypris acanthoides

$\dagger S$. cerastes

${ }^{*} S$. trapezoides

$\dagger$ Theriosynoecum forbesi

Wolburgia visceralis

C-phase species represent less than $2 \%$ of the fauna:

${ }^{*}$ Cypridea dunkeri, ${ }^{*}+C$. primaeva and ${ }^{*} C$. tumescens

This Faunicycle also appears to be present only in the marginal areas.

Faunicycle 3, Ridgeway. 1107 specimens from $\mathrm{Ay}, \mathrm{Pq}$ and $\mathrm{Sw}$.

S-phase species represent $92 \%$ of the fauna:

Darwinula leguminella

Fabanella ansata

F. boloniensis $19 \%$

Klieana alata $25 \%$

Mantelliana purbeckensis 33\%

Paraschuleridea buglensis

Protocythere serpentina
Procytheropteron barkeri

Rhinocypris decipiens

$R$. jurassica

Scabriculocypris cerastes

$S$. trapezoides

+ Stenestroemia fragilis

C-phase species represent $8 \%$ of the fauna:

Cypridea dunkeri, C. primaeva and C. tumescens

Faunicycle 4, Stair. 72 specimens from $\mathrm{He}, \mathrm{Pq}, \mathrm{PU}$ and WN.

Most of this cycle consists of evaporite deposits and few ostracods were seen. The fauna appears to be similar to that of the previous cycle.

ASSEMBLAGE 2

Species of Macrodentina are no longer seen; instead, Fabanella boloniensis is the dominant form (46\%). C-phase species are more abundant, forming up to $25 \%$ of the assemblage, with Cypridea dunkeri as the dominant species.

Faunicycle 5, Swindon. 32 specimens from $\mathrm{Br}, \mathrm{DB}, \mathrm{Fa}$, $\mathrm{GD}$ and $\mathrm{He}$.

This faunicycle follows the main evaporite phase and the ostracod fauna was not fully re-established. S-phase species, mainly $F$. boloniensis and Mantelliana purbeckensis, represent $75 \%$ of the fauna. The $\mathbf{C}$-phase species are as before: Cypridea dunkeri, $C$. primaeva and C. tumescens.

Faunicycle 6, Upwey. 586 specimens from $\mathrm{Bg}, \mathrm{Br}, \mathrm{CD}$, $\mathrm{DB}, \mathrm{Fa}, \mathrm{Mo}, \mathrm{Pe}$ and Wa.

The fauna is still dominated by S-phase species (72\%), mostly $M$. purbeckensis (38\%) with Klieana alata (27\%). Two new forms are Wolburgia polyphema andDarwinula oblonga. $C$. dunkeri is the most abundant $\mathbf{C}$-phase species $(23 \%)$ and is accompanied by $C$. primaeva, $C$. tumescens and a new form, $C$. simplissima nom. nov. (see later).

Faunicycle 7, Hard Cockle. 3316 specimens from $\mathrm{Bg}, \mathrm{Br}$, CD, D B, Fa, GD, Gu, He, Ki, Mo, NP, Pe, Po and Wa.

S-phase species represent $55 \%$ of the fauna. Fabanella boloniensis is the dominant species (47\%), accompanied by Mantelliana purbeckensis and $M$. wealdensis.

The C-phase species are $C$. dunkeri $(35 \%), C$. tumescens $(10 \%)$ and a new form, $C$. peltoides.

Faunicycle 8, Wardour. 1280 specimens from $\mathrm{Bg}, \mathrm{Br}$, $\mathrm{CD}, \mathrm{DB}, \mathrm{Fa}, \mathrm{Gu}, \mathrm{Ki}, \mathrm{Mo}, \mathrm{Ne}, \mathrm{NP}$ and Wa.

S-phase species represent $63 \%$ of the fauna, mainly $M$. purbeckensis $(44 \%)$ and $F$. boloniensis $(17 \%)$.

The dominant $\mathbf{C}$-phase species are C.dunkeri $(17 \%)$ and $C$. tumescens $(17 \%)$. 
Faunicycle 9, Lower Soft Cockle. 1943 specimens from As, Bg, Br, CD, DB, Fa, Gu, Ki, Mo, NP, Po and Wa.

S-phase species represent $84 \%$ of the fauna suggesting an increase in salinity. $F$. boloniensis is the dominant form (66\%) with Bisulcocypris striata (8\%).

C-phase species are mainly $C$. tumescens and $C$. dunkeri. Cypridea granulosa protogranulosa, the earliest subspecies of $C$. granulosa, appears in this faunicycle but is very scarce.

Faunicycle 10, Upper Soft Cockle. 1133 specimens from $\mathrm{Bg}, \mathrm{Br}, \mathrm{DB}, \mathrm{Fa}, \mathrm{GD}, \mathrm{Gu}, \mathrm{He}, \mathrm{Ki}, \mathrm{Mo}, \mathrm{NP}, \mathrm{Po}$ and $\mathrm{Wa}$.

Salinity as before, $S$-phase species represent $85 \%$ of the fauna, mostly $F$. boloniensis $(83 \%)$.

The $\mathbf{C}$-phase species are mainly $C$. dunkeri and $C$. peltoides. Cypridea peltoides eurygaster is a new subspecies which appears in this cycle but is rare.

Faunicycle 11, Penshurst. 858 specimens from $\mathrm{Bg}, \mathrm{Br}$, $\mathrm{DB}, \mathrm{Fa}, \mathrm{Gu}$ and Wa.

S-phase species represent $60 \%$ of the fauna. They are mainly $F$. boloniensis (55\%).

Of the C-phase species, $26 \%$ are $C$. peltoides.

\section{ASSEMBLAGE 3}

In this assemblage $\mathbf{C}$-phase species for the first time, in the Mountfield Faunicycle, represent more than $50 \%$ of the ostracod fauna. The dominant forms are Cypridea dunkeri and C. granulosa. In the S-phase, F. boloniensis is still the dominant species.

Faunicycle 12, Ringstead. 1616 specimens from As, Br, $\mathrm{CD}, \mathrm{DB}, \mathrm{Fa}, \mathrm{GD}, \mathrm{Gu}, \mathrm{He}, \mathrm{Mo}, \mathrm{NP}$ and Wa.

S-phase species total $75 \%$ of the fauna. $F$. boloniensis is still dominant (54\%), accompanied by $M$. purbeckensis (6\%).

C-phase species. As before, C. tumescens (15\%), $C$. peltoides $(7 \%), C$. dunkeri $(5 \%)$ and rare specimens of C. granulosa.

Faunicycle 13, Robertsbridge. 1484 specimens from $\mathrm{Br}$, $\mathrm{CD}, \mathrm{Fa}, \mathrm{GD}, \mathrm{Gu}, \mathrm{Mo}, \mathrm{NP}, \mathrm{Pe}, \mathrm{Po}$ and Wa.

S-phase species represent $84 \%$ of the fauna, mainly F. boloniensis (74\%), with some M. purbeckensis (5\%).

Of the C-phase species, $C$. dunkeri is the dominant form with $C$. tumescens.

Faunicycle 14, Burwash. 4359 specimens from $\mathrm{Br}, \mathrm{CD}$, $\mathrm{Fa}, \mathrm{GD}, \mathrm{Gu}, \mathrm{He}, \mathrm{Mo}$ and $\mathrm{Wa}$.

S-phase species represent $61 \%$ of the fauna, again mainly $F$. boloniensis (40\%), with Scabriculocypris trapezoides $(6 \%)$ and Darwinula leguminella $(6 \%)$.

C-phase species are now more abundant $(39 \%)$. The dominant species is $C$. peltoides $(29 \%) ; C$. sagena is a new form whilst $C$. granulosa is still rare.
Faunicycle 15, Mountfield. 8597 specimens from As, Bg, $\mathrm{Br}, \mathrm{DB}, \mathrm{Fa}, \mathrm{GD}, \mathrm{Gu}, \mathrm{Hd}, \mathrm{He}, \mathrm{Ki}, \mathrm{Mo}$ and $\mathrm{NP}$.

S-phase species represent $41 \%$ of the fauna. $F$. boloniensis (14\%), $D$. leguminella and $D$. oblonga (together 11\%), Pseudoparacypridopsis mountfieldensis $(5 \%)$ and $S$. trapezoides $(4 \%)$.

Of the C-phase species, Cypridea granulosa is now the dominant species (34\%), with $C$. dunkeri $(9 \%)$ and C. sagena (7\%). New forms appearing are Cypridea lata and $C$. varians. From this cycle, up to and including the Royal Faunicycle, $C$.granulosa is the most abundant and characteristic species.

Faunicycle 16, Goldspur. 8973 specimens from $\mathrm{Bg}, \mathrm{Br}$, $\mathrm{CD}, \mathrm{DB}, \mathrm{Fa}, \mathrm{GD}, \mathrm{Gu}, \mathrm{Hd}, \mathrm{He}, \mathrm{Ki}, \mathrm{Mo}$ and NP.

S-phase species represent $43 \%$ of the fauna. $F$. boloniensis is the dominant form (20\%) with $S$. trapezoides $(6 \%)$ and $D$. leguminella (5\%).

C-phase species are $C$. granulosa $(31 \%), C$. peltoides $(11 \%)$ and $C$.dunkeri $(6 \%)$. There are three new forms: Cypridea orientalis, C. coelnothi and $C$. delicatula.

The base of the Goldspur Faunicycle marks the base of the Middle Purbeck Beds, but in general the fauna is not very different from that of the previous cycle.

Faunicycle 17, Ashdown. 4341 specimens from As, Bg, $\mathrm{Br}, \mathrm{CD}, \mathrm{DB}, \mathrm{Fa}, \mathrm{GD}, \mathrm{Mo}, \mathrm{NP}, \mathrm{Pe}$ and Wa.

S-phase species represent $42 \%$ of the fauna; $M$. wealdensis is the dominant form $(23 \%)$ with $F$. boloniensis $(9 \%)$ and $S$. trapezoides $(4 \%)$.

Of the C-phase species, C. granulosa (42\%) is dominant. For the first time, the subspecies $C$. granulosa granulosa is the most abundant subspecies (26\%). C. delicatula represents $7 \%$ of the fauna, C. dunkeri (4\%) and C. sagena (4\%).

Faunicycle 18, Swanage. 4564 specimens from $\mathrm{Br}, \mathrm{CD}$, $\mathrm{DB}, \mathrm{Fa}, \mathrm{GD}, \mathrm{Hd}, \mathrm{Ki}, \mathrm{Mo}, \mathrm{NP}$ and $\mathrm{Wa}$.

S-phase species represent $44 \%$ of the fauna. The dominant species are $F$. boloniensis $(14 \%), D$. leguminella (14\%) and Eoparacypris weedonensis. As the salinity decreases, darwinulids become more important in the S-phase and $F$. boloniensis less so.

Of the C-phase species, C. granulosa accounts for $32 \%$ of the fauna (mainly the subspecies granulosa, $29 \%$ ), with C. dunkeri (9\%) and C. sagena (5\%).

\section{ASSEMBLAGE 4}

Cypridea granulosa reaches its maximum abundance as the dominant $\mathbf{C}$-phase species in this Assemblage and a new subspecies, $C$. granulosa fasciculata, appears which eventually becomes the commonest form of the species.

There appears to be a steady progression towards a lesss saline environment, this is only briefly interrupted by the Cinder Beds episode.

In the S-phases, darwinulids become increasingly abundant. 
Faunicycle 19, Netherfield. 5337 specimens from $\mathrm{Br}$, CD, DB, Fa, GD, Hd, Mo, NP, Po and Wa.

S-phase species represent $28 \%$ of the fauna, mainly D. leguminella $(8 \%)$ and $F$. boloniensis $(4 \%)$.

Of the $\mathbf{C}$-phase species, $C$. granulosa is the dominant form (33\%). The subspecies $C$. granulosa fasciculata appears for the first time but is not abundant. There are several new forms: Cypridea swanagensis, C. dolabrata, $C$. inaequalis, $C$. penshurstensis, $C$. aemulans nom. nov. (see later) and the important species, C.posticalis, which has only been found in this and the following faunicycle.

Faunicycle 20, Durlston. 5668 specimens from $\mathrm{Br}, \mathrm{CD}$, $\mathrm{DB}, \mathrm{GD}, \mathrm{Hd}, \mathrm{Ki}, \mathrm{Mo}, \mathrm{MW}, \mathrm{NP}$ and Wa.

S-phase species represent $33 \%$ of the fauna, mainly F. boloniensis (9\%), D. leguminella (5\%) and Orthonotacythere diglypta (5\%).

C-phase species are Cypridea granulosa (23\%), C. posticalis (10\%), C. lata (10\%), C. swanagensis (7\%), C. coelnothi $(6 \%)$ etc.

Faunicycle 21, Peveril. 4468 specimens from $\mathrm{Br}, \mathrm{CD}$, $\mathrm{DB}, \mathrm{Fa}, \mathrm{GD}, \mathrm{Hd}$, Mo and Wa.

S-phase species represent $26 \%$ of the fauna, mainly $F$. boloniensis (8\%) and D. leguminella $(7 \%)$.

Of the C-phase species, $C$. granulosa is dominant $(64 \%)$, in particular the subspecies $C$. granulosa fasciculata (56\%).

Faunicycle 22, Cinder Beds. 3177 specimens from As, $\mathrm{Br}, \mathrm{CD}, \mathrm{DB}, \mathrm{Fa}, \mathrm{GD}, \mathrm{Hd}, \mathrm{Ki}, \mathrm{Mo}, \mathrm{NW}, \mathrm{PC}$ and $\mathrm{Wa}$.

S-phase species represent $97 \%$ of the fauna with Galliaecytheridea postsinuata $(66 \%)$ as the dominant form, with Klieana dictyota, $D$. leguminella and other species. This unit is an ostreid rich shell bed usually about $3 \mathrm{~m}$ thick. In Dorset, it is almost entirely composed of shells but in the Weald there is a muddy matrix.

C-phase species are much reduced and are mainly C. granulosa fasciculata. The species Cypridea altissima is present but this may only be an unornamented form of C. granulosa.

This faunicycle represents a dramatic increase in salinity which, however, need not have been of long duration. There is little overall disturbance in the composition of the $\mathbf{C}$-phase faunas and they become reestablished in the succeeding cycle.

Faunicycle 23, Nothe. 1012 specimens from Ar, As, Bg, $\mathrm{Br}, \mathrm{CD}, \mathrm{DB}, \mathrm{Fa}, \mathrm{Gu}, \mathrm{Hd}, \mathrm{Ki}, \mathrm{Mo}, \mathrm{NP}, \mathrm{Pe}$ and Po.

S-phase species represent $43 \%$ of the fauna. $G$. postsinuata $(18 \%)$ is still present with $D$. leguminella (13\%).

Of the C-phase species, $C$. granulosa is dominant (37\%) is the dominant form. Cypridea amisia is a new form at this level.
Faunicycle 24, Croydon. 579 specimens from $\mathrm{Br}, \mathrm{CD}$, DB, Fa, Hd and Mo.

S-phase species represent $63 \%$ of the fauna in which $G$. postsinuata is still the dominant form (34\%) with Bisulcocypris striata (16\%) and D. leguminella (11\%). C-phase species are mostly $C$. granulosa fasciculata $(35 \%)$.

Faunicycle 25, Royal. 55 specimens from $\mathrm{Br}, \mathrm{CD}, \mathrm{DB}$, $\mathrm{Hd}$ and Mo? provide only a sparse fauna.

S-phase species represent $16 \%$ of the fauna, mainly $D$. leguminella $(7 \%)$ and $B$. striata (4\%). G. postsinuata was not found. A marked reduction in salinity is evident.

Of the C-phase species, $C$. granulosa fasciculata is dominant $(69 \%)$, with $C$. altissima $(16 \%), C$. lata, C. amisia and $C$. simplissima.

\section{ASSEMBLAGE 5}

In this assemblage, Cypridea granulosa, though present, is no longer the dominant $\mathbf{C}$-phase species, being replaced by Cypridea amisia and $C$. vidrana. In the S-phase, Fabanella boloniensis has been largely replaced by Macrodentina mediostricta.

Faunicycle 26, Corfe. 1066 specimens from $\mathrm{Bg}, \mathrm{Br}, \mathrm{CD}$, $\mathrm{Gu}, \mathrm{Hd}, \mathrm{Mo}$ and $\mathrm{Wa}$.

S-phase species represent $62 \%$ of the fauna and include $F$. boloniensis (17\%), M. mediostricta $(11 \%)$, Damonella ellipsoidea (14\%) and Scabriculocypris durlestonensis (9\%).

C-phase species are Cypridea lata (16\%) with $C$. amisia, $C$. simplissima, C. aemulans and a few C. granulosa fasciculata.

Faunicycle 27, Worth. 742 specimens from $\mathrm{Bg}, \mathrm{Br}, \mathrm{CD}$, $\mathrm{DB}, \mathrm{Fa}, \mathrm{Hd}$ and Mo.

S-phase species represent $31 \%$ of the fauna with F. boloniensis (13\%), Theriosynoecum forbesi (5\%), Klieana thoracina, $M$. mediostricta, $O$. diglypta and other species.

C-phase species are C. granulosa fasciculata (16\%), C. altissima $(10 \%)$, C. lata $(14 \%)$, with the two new forms Cypridea darvelensis (6\%) and C. tuberculata langtonensis $(6 \%)$.

Faunicycle 28, Langton. 1380 specimens from $\mathrm{Br}, \mathrm{CD}$, $\mathrm{DB}, \mathrm{Fa}, \mathrm{Gu}, \mathrm{Hd}$, Mo and Wa.

S-phase species represent $37 \%$ of the fauna. B. striata is dominant (10\%) with Rhinocypris jurassica, $M$. mediostricta, darwinulids and other species.

C-phase species are C. amisia (dominant, 24\%), C. lata $(10 \%), C$. granulosa fasciculata (7\%), C. penshurstensis $(7 \%)$ and $C$. altissima (6\%). There are three new forms:- Cypridea vidrana, $C$. obliqua and $C$. andersoni. 
Faunicycle 29, Scallop. 1260 specimens from Br, CD, $\mathrm{DB}, \mathrm{Fa}, \mathrm{Gu}, \mathrm{Mo}$ and Wa.

S-phase species represent $35 \%$ of the fauna. $M$. mediostricta is the dominant form (21\%) with $D$. leguminella (4\%) and other species.

C-phase species are $C$. lata $(16 \%), C$. penshurstensis (14\%), C. amisia (12\%), C. simplissima and others. New forms first seen here are Cypridea propunctata, $C$. brevirostrata and $C$. bimammata; forms resembling $C$. alta and $C$. setina are also found.

Faunicycle 30, Studland. 1028 specimens from $\mathrm{Br}, \mathrm{CD}$, $\mathrm{Fa}, \mathrm{Gu}, \mathrm{Hd}$ and $\mathrm{Mo}$.

S-phase species represent $27 \%$ of the fauna with Orthonotacythere nodosaria (8\%), D. leguminella (6\%), Stenestroemia fragilis $(5 \%), M$. mediostricta $(3 \%)$ and other species.

C-phase species are $C$. lata (dominant, 33\%), $C$. vidrana $(13 \%), C$. penshurstensis $(8 \%)$ and $C$. simplissima (7\%). C. setina and $C$. alta are definite components of this fauna, but are rare. There is a new form which resembles Cypridea wicheri.

Faunicycle 31, Bacon. 2681 specimens from $\mathrm{Br}, \mathrm{CD}$, $\mathrm{DB}, \mathrm{Fa}, \mathrm{Gu}, \mathrm{Hd}, \mathrm{Mo}$ and Wa.

S-phase species represent $31 \%$ of the fauna and include $D$. leguminella $(9 \%)$ and $M$. mediostricta $(9 \%)$.

C-phase species include C. vidrana (19\%), C. amisia $(16 \%), C$. penshurstensis $(8 \%)$ and $C$. lata (6\%). Cypridea setina is present but scarce.

Faunicycle 32, Poxwell. 2182 specimens from $\mathrm{Br}, \mathrm{CD}$, $\mathrm{DB}, \mathrm{Fa}, \mathrm{Gu}, \mathrm{Hd}, \mathrm{Mo}$ and Wa.

S-phase species represent $51 \%$ of the fauna. The dominant species are Orthonotacythere rimosa (22\%) with $D$. leguminella $(10 \%), M$. mediostricta $(7 \%)$ and F. boloniensis $(6 \%)$.

C-phase species include Cypridea vidrana (dominant, $13 \%), C$. aemulans $(8 \%), C$. lata $(8 \%)$ and $C$. orientalis $(6 \%)$.

\section{ASSEMBLAGE 6}

This assemblage is marked by the increasing dominance of such characteristic Upper Purbeck species as Cypridea setina, $C$. propunctata and $C$. wicheri.

Faunicycle 33, Greenwood. 1835 specimens from $\mathrm{Br}$, $\mathrm{CD}, \mathrm{DB}, \mathrm{Fa}, \mathrm{Mo}, \mathrm{NP}$ and Wa.

S-phase species represent $36 \%$ of the fauna with $M$. mediostricta as the dominant form $(20 \%)$ and darwinulids.

C-phase species include C. penshurstensis (42\%), C. brevirostrata $(9 \%)$, C. simplissima (7\%) and other species. Both C. setina and C. propunctata are present but are rare.
Faunicycle 34, Lulworth. 2143 specimens from CD, $\mathrm{DB}, \mathrm{Fa}, \mathrm{Mo}, \mathrm{NP}$ and Wa.

S-phase species represent $34 \%$ of the fauna, with $B$. striata (13\%), M. mediostricta (6\%), darwinulids (18\%) and other species.

Of the $\mathbf{C}$-phase species, $C$. penshurstensis (57\%) is the most abundant form with $C$. wolburgi $(17 \%), C$. setina rectidorsata (6\%) and $C$. setina setina (1\%). A characteristic but scarce subspecies, $C$. alta formosa, is also present.

This cycle marks the base of the Upper Purbeck during which $C$. setina and $C$. propunctata become the most typical species.

Faunicycle 35, Mupes. 2773 specimens from CD, DB, $\mathrm{Fa}$, Mo and Wa.

S-phase species represent $26 \%$ of the fauna, with darwinulids $(10 \%), R$. jurassica $(7 \%), B$. striata $(6 \%)$ and a few specimens of $M$. mediostricta.

C-phase species are $C$. setina $(20 \%), C$. propunctata $(12 \%), C$. alta $(11 \%)$ and $C$. alta formosa $(6 \%)$. The first examples of $C$. laevigata and $C$. ventrosa are found in this faunicycle.

Faunicycle 36, Brede. 3146 specimens from CD, DB, $\mathrm{Fa}, \mathrm{Ki}$, Mo and Wa.

S-phase species represent $10 \%$ of the fauna, being mostly $D$. leguminella and $D$. oblonga .

C-phase species include $C$. propunctata (dominant, $32 \%)$, with $C$. setina (24\%), C. alta $(11 \%)$ and $C$. wicheri $(8 \%)$.

Faunicycle 37, Tisbury. 2786 specimens from CD, DB, Mo, NP and Wa.

S-phase species represent $14 \%$ of the fauna and are mostly darwinulids (10\%).

Of the C-phase species, $C$. propunctata is dominant (25\%), with C. setina (18\%), C. alta (17\%) and other species.

Faunicycle 38, Durdle. 2391 specimens from CD, DB, $\mathrm{Fa}$, Mo and Wa.

S-phase species represent $8 \%$ of the fauna. They are mainly darwinulids (5\%) with $R$. jurassica $(2 \%)$.

C-phase species are $C$. setina (dominant, $25 \%$ ), with C. wicheri $(23 \%)$ and C. alta (21\%). C. alta formosa is now scarce.

Faunicycle 39, Tyneham. 1784 specimens from $C D$, $\mathrm{DB}, \mathrm{Fa}, \mathrm{Gu}, \mathrm{NP}$ and $\mathrm{Wa}$.

S-phase species represent $16 \%$ of the fauna, mainly darwinulids (11\%) with $R$. jurassica and other species.

C-phase species include $C$. setina (dominant, 33\%), C. propunctata $(14 \%), C$. alta $(13 \%)$ and $C$. wicheri (7\%). 


\section{ASSEMBLAGE 7}

This fauna is essentially a continuation of Assemblage 6 but with some new elements such as the remarkable species Cypridea morula (PI. 8, fig. 16). Cypridea dolabrata and $C$. wicheri both develop a number of subspecies and $C$. brevirostrata becomes abundant. In the upper part of this assemblage the typical Wealden form C. tuberculata becomes the dominant $\mathbf{C}$-phase species. Although the Hastings Faunicycle (41) has been previously taken as the base of the Wealden, the transition from the Purbeck is gradual and it is only in the Maresfield and Hythe Faunicycles (45-46) that typical Wealden faunas become firmly established. There is also a change in the ornament pattern of $C$. wicheri in the Bexhill Faunicycle (42) and this could well be taken as indicating a transition from Purbeck to Wealden faunas.

Faunicycle 40, Battle. 2237 specimens from CD, DB, $\mathrm{Gu}, \mathrm{NP}$ and Wa.

S-phase species represent $18 \%$ of the fauna, mainly $R$. jurassica (9\%) with darwinulids and other species.

Of the $\mathbf{C}$-phase species, $C$. propunctata is the dominant form (35\%), with C. aemulans (22\%) and C. setina (11\%).

Faunicycle 41, Hastings. 663 specimens from CD, Fa, $\mathrm{Gl}, \mathrm{He}, \mathrm{Ki}, \mathrm{Po}$ and Wa.

S-phase species represent $10 \%$ of the fauna and include darwinulids (7\%), with $R$. jurassica and Theriosynoecum alleni (first appearance).

Of the C-phase species, C. brevirostrata is the dominant form (41\%), with C. wicheri (22\%), C. setina (18\%) and the scarce but characteristic $C$. tuberculata adjuncta. There are also a few early examples of forms comparable with $C$. bispinosa, $C$. menevensis, $C$. paulsgrovensis and C. recta.

Anderson (1962) took this Faunicycle to be the earliest of the Wealden but this was no more than a convention. There is neither a distinct faunal nor a lithological change at this level.

Faunicycle 42, Bexhill. 1606 specimens from Ar, CD, $\mathrm{He}, \mathrm{Ki}, \mathrm{Pe}, \mathrm{Po}$ and Wa.

S-phase species represent $13 \%$ of the fauna, mainly darwinulids (7\%), with $R$. jurassica (4\%) and $T$. alleni (2\%).

C-phase species include C. laevigata (27\%), C. brevirostrata $(26 \%), C$. morula (16\%) and $C$. setina $(9 \%)$. $C$. morula is known only from this and the succeeding cycle. A form which may be $C$. melvillei appears for the first time in this cycle.

Faunicycle 43, Eastbourne. 3142 specimens from As, $\mathrm{CD}, \mathrm{He}, \mathrm{Ki}$ and Wa.

S-phase species represent $30 \%$ of the fauna. They are mainly $R$. jurassica (27\%), with Timiriasevia punctata and darwinulids.

C-phase species include $C$. wicheri (19\%), C. morula (14\%), C. setina (13\%) and C. dolabrata (12\%).
Faunicycle 44, Nutfield. 1049 specimens from CD, GI, $\mathrm{He}, \mathrm{Ki}, \mathrm{Po}$ and Wa.

S-phase species represent $4 \%$ of the fauna with darwinulids (3\%) and $T$. alleni.

Of the C-phase species, $C$. dolabrata is dominant (55\%), with C. tuberculata (11\%), C. paulsgrovensis (10\%), C. menevensis (7\%), C. setina, C. aculeata and C. recta.

This fauna now has a typical early Wealden aspect.

Faunicycle 45, Maresfield. 160 specimens only, from $\mathrm{CD}, \mathrm{Fa}, \mathrm{Gl}, \mathrm{He}, \mathrm{Ki}, \mathrm{Pe}$, Po and We.

No $S$-phase species seen.

Of the C-phase species, $C$. tuberculata is dominant $(56 \%)$, with $C$. menevensis $(16 \%), C$. paulsgrovensis $(8 \%), C$. aculeata (7\%), C. bispinosa (6\%) and C. recta.

Faunicycle 46, Hythe. 92 specimens only from $\mathrm{He}$, a very sparse fauna.

No S-phase species seen.

C-phase species are C. tuberculata (dominant, 37\%), with $C$. recta $(18 \%), C$. paulsgrovensis $(16 \%)$ and C. menevensis (12\%).

\section{ASSEMBLAGE 8}

This ostracod assemblage is found in the lower part of the Wadhurst Clay. The S-phases are dominated by Theriosynoecum alleni and Rhinocypris jurassica. The common C-phase species are C. laevigata and C. tuberculata.

Faunicycle 47, Rye. 2868 specimens from CD, Gl, Wa, We and WP.

S-phase species represent $40 \%$ of the fauna. $T$. alleni makes up 20\%, and others present include a new form, Mantelliana phillipsiana, $R$. jurassica and darwinulids.

C-phase species include Cypridea blackbushensis $(26 \%)$ a new arrival, $C$. paulsgrovensis $(24 \%), C$. westfieldensis another new form, $C$. menevensis and $C$. laevigata. C. melvillei was seen but was very scarce.

Faunicycle 48, Winchester. 2391 specimens from CD, $\mathrm{Gl}, \mathrm{Wa}, \mathrm{We}$ and WP.

S-phase species represent $15 \%$ of the fauna, mainly $T$. alleni $(8 \%)$, with $R$. jurassica, M. phillipsiana and darwinulids.

Of the C-phase species, C. paulsgrovensis is dominant (72\%) with C. tuberculata (8\%), C. blackbushensis, $C$. westfieldensis, $C$. menevensis and a few $C$. melvillei.

Faunicycle 49, Lydd. 2604 specimens from CD, Gl, Ki, LM, Wa, We and WP.

S-phase species represent $31 \%$ of the fauna and include $T$. alleni (16\%), with Damonella ellipsoidea, $F$. boloniensis and darwinulids.

Of the C-phase species, $C$. tuberculata is dominant (42\%), with C. paulsgrovensis (26\%), C. menevensis, C. laevigata and others. 
Faunicycle 50, Horsted. 1495 specimens from CD, Gl, LM, Wa, We and WP.

S-phase species represent $19 \%$ of the fauna and include $T$. alleni $(13 \%)$ with $R$. jurassica, $M$. phillipsiana and darwinulids.

C-phase species are C. tuberculata (41\%), C. paulsgrovensis $(32 \%), C$. laevigata, $C$. menevensis and C. melvillei.

Faunicycle 51, Kingsclere. 4488 specimens from Gl, LM, Wa, We and WP.

S-phase species represent $36 \%$ of the fauna, with $T$. alleni $(26 \%), R$. jurassica, darwinulids and other species.

C-phase species are $C$. laevigata $(19 \%), C$. melvillei $(15 \%), C$. paulsgrovensis $(12 \%), C$. tuberculata, $C$. menevensis and two new forms, Cypridea frithwaldi and C. lasius.

Faunicycle 52, St. Leonards. 4162 specimens from $C D$, $\mathrm{Co}, \mathrm{Gl}, \mathrm{Ki}, \mathrm{LM}, \mathrm{Wa}, \mathrm{We}$ and WP.

S-phase species represent $41 \%$ of the fauna, including $T$. alleni $(22 \%), R$. jurassica $(14 \%)$ and darwinulids.

C-phase species are $C$. paulsgrovensis $(24 \%), C$. laevigata (20\%), C. menevensis and $C$. melvillei, with the new forms Cypridea helenae, C. pendae, C. valdensis and $C$. verrucosa.

Faunicycle 53, Fairlight. 5202 specimens from CD, Co, Gl, Ki, LM, Wa, We and WP.

S-phase species represent $34 \%$ of the fauna; they include $R$. jurassica (12\%), T. alleni $(9 \%)$, darwinulids and a new form, Mantelliana mantelli.

C-phase species include C. paulsgrovensis (31\%), C. laevigata (12\%), C. menevensis, C. melvillei, C. pendae, and three new forms, Cypridea arenosa, $C$. giffordi and $C$. asseri.

\section{ASSEMBLAGE 9}

This assemblage is present in the upper part of the Wadhurst Clay. The S-phase species in this assemblage show little change, but in the $\mathbf{C}$-phase, the previously common species $C$. paulsgrovensis, $C$. laevigata and $C$. tuberculata are replaced by $C$. melvillei, $C$. recta, $C$. aculeata and $C$. bispinosa. Cypridea arenosa, with some subspecies of $C$. laevigata and $C$. aculeata are characteristic.

Faunicycle 54, Lindfield. 3276 specimens from CD, Co, FL, Gl, Ki, LM, Wa, We and WP.

S-phase species represents $23 \%$ of the fauna, mainly darwinulids $(11 \%)$, with $T$. alleni $(7 \%)$ and $R$. jurassica (5\%).

C-phase species are $C$. paulsgrovensis $(19 \%), C$. aculeata $(12 \%), C$. arenosa $(9 \%), C$. blackbushensis $(8 \%), C$. recta (7\%), C. menevensis, C. pendae and a new form - Cypridea vericae.
Faunicycle 55, Wadhurst. 3076 specimens from CD, FL, $\mathrm{Gl}, \mathrm{Ki}, \mathrm{LM}, \mathrm{Wa}$ and WP.

S-phase species represent $22 \%$ of the fauna, mainly darwinulids (8\%) and $R$. jurassica (4\%), with $T$. alleni, $M$. phillipsiana and others.

C-phase species include $C$. bispinosa (22\%), $C$. aculeata $(15 \%), C$. recta $(18 \%)$ and $C$. arenosa $(8 \%)$.

Faunicycle 56, Crowhurst. 4381 specimens from $C D$, $\mathrm{Co}, \mathrm{FL}, \mathrm{Gl}, \mathrm{Ki}$, Wa, We and WP.

S-phase species represent $20 \%$ of the fauna, mainly darwinulids (15\%), with $R$. jurassica, M. phillipsiana and $T$. alleni.

C-phase species include $C$. recta (29\%) mostly the subspecies $C$. recta tillsdenensis, $C$. bispinosa $(18 \%), C$. melvillei (14\%) and C. aculeata.

Faunicycle 57, Hawkhurst. 9376 specimens from $\mathrm{Co}$, $\mathrm{FL}, \mathrm{Gl}, \mathrm{Ki}$, Wa, We and WP.

S-phase species represent $17 \%$ of the fauna, mainly darwinulids $(10 \%)$ and $R$. jurassica $(6 \%)$, with $T$. alleni and $M$. phillipsiana.

C-phase species include C. melvillei (36\%), $C$. aculeata (18\%) and C. bispinosa (14\%).

Faunicycle 58, Fletching. 1621 specimens from CD, FL, $\mathrm{Ki}$ and WP.

S-phase species represent $23 \%$ of the fauna with darwinulids (11\%), R. jurassica (9\%), T. alleni and Damonella pygmaea.

C-phase species include $C$. melvillei (30\%), $C$. verrucosa $(18 \%), C$. bispinosa (13\%) and C. aculeata .

Faunicycle 59, Chilcombe. 3978 specimens from CD, $\mathrm{CL}, \mathrm{Cu}, \mathrm{Ki}, \mathrm{PQ}, \mathrm{Sh}$ and Wa.

S-phase species represent $14 \%$ of the fauna with $T$. alleni $(5 \%), M$. phillipsiana (4\%), darwinulids, $R$. jurassica and others.

C-phase species are $C$. recta $(41 \%)$, with $C$. tuberculata, C. verrucosa, $C$. valdensis and C. bispinosa.

Faunicycle 60, Grinstead. 786 specimens from $\mathrm{Cu}, \mathrm{Hi}$, $\mathrm{Ki}, \mathrm{PQ}$ and Wa.

S-phase species represent $22 \%$ of the fauna with darwinulids (12\%), T. alleni $(5 \%)$ and $M$. phillipsiana $(5 \%)$.

C-phase species are C. bispinosa (48\%), with $C$. tuberculata, C. recta and C. aculeata.

\section{ASSEMBLAGE 10}

The fauna is little changed. $\mathbf{C}$-phase faunas consist largely of $C$. bispinosa, $C$. recta and $C$. tuberculata, and the S-phase faunas of $T$. alleni with darwinulids. The subspecies $C$. recta tillsdenensis is an important component of this assemblage. In the upper part of the assemblage, the faunas are sparse and known from very few localities so that details given for each Faunicycle are unreliable. 
Faunicycle 61, Philpotts. 964 specimens from CL, $\mathrm{Cu}$, $\mathrm{Hi}, \mathrm{PQ}$ and Wa.

S-phase species represent $15 \%$ of the fauna with $R$. jurassica (7\%), M. phillipsiana, T. alleni and darwinulids.

C-phase species include $C$. bispinosa (28\%), C. tuberculata $(21 \%)$, C. recta $(20 \%)$ and C. verrucosa $(13 \%)$.

Faunicycle 62, Copyhold. 215 specimens from $\mathrm{Cu}, \mathrm{PQ}$ and Wa.

S-phase species represent $10 \%$ of the fauna. $M$. phillipsiana (9\%) occurs with $R$. jurassica and darwinulids.

C-phase species are $C$. recta (mostly subspecies tillsdenensis) (71\%), C. tuberculata, C. bispinosa and C. laevigata.

Faunicycle 63, Highbridge. 346 specimens from Ki.

S-phase species represent $2 \%$ of the fauna and are mostly darwinulids.

C-phase species include $C$. recta (mostly the subspecies tillsdenensis) (53\%), C. melvillei (33\%) and C. aculeata.

Faunicycle 64, Salehurst. 108 specimens from $\mathrm{Cu}$.

S-phase species represent $9 \%$ of the fauna and all are darwinulids.

C-phase species are $C$. recta (mostly the subspecies tillsdenensis) (68\%), C. valdensis (16\%), C. aculeata, C. tuberculata and C. melvillei.

Faunicycle 65, Bathurst. 79 specimens from $\mathrm{Cu}$ and PQ.

S-phase species represent $8 \%$ of the fauna and are mostly darwinulids.

C-phase species are $C$. recta (mostly the subspecies tillsdenensis) (49\%), C. bispinosa (28\%) and C. valdensis $(15 \%)$.

Faunicycle 66, Peasemarsh. 50 specimens from $\mathrm{Cu}$ and Sh.

S-phase species represent $34 \%$ of the fauna with $M$. wealdensis (18\%) and darwinulids (16\%).

C-phase species are $C$. recta (mainly the subspecies tillsdenensis) (40\%), C. tuberculata (12\%), C. valdensis $(10 \%)$ and C. bispinosa (2\%).

Faunicycle 67, Cuckfield. 151 specimens from $\mathrm{Cu}$ and Sh.

S-phase species represent $65 \%$ of the fauna. T. alleni $(60 \%)$ occurs with $M$. phillipsiana and darwinulids.

C-phase species are C. bispinosa (20\%), C. laevigata $(10 \%)$, C. recta tillsdenensis (5\%).

\section{ASSEMBLAGE 11}

The basal part of the Weald Clay (Horsham phase) contains a distinctive assemblage completely dominated by $C$. dorsispinata in the $\mathbf{C}$-phase and with Miocytheridea henfieldensis and Theriosynoecum fittoni as the S-phase forms. Whatever the reason for these impoverished faunas and the disappearance of most of the previously existing species, the base of the Weald Clay is marked by a profound faunal change. Although at first ostracods are scarce, they soon become abundant although relatively few species are present. In Anderson (1967) the terms Horsham Group and Henfield Group were used to refer to the ostracod assemblages in the Lower Weald Clay. In view of the lithological connotation now attributed to the word 'Group', these are re-named as 'phases'.

Faunicycle 68, Sevenoaks. 6 specimens only, from $\mathrm{He}$ and Wd.

S-phase species are represented by five specimens. All are Darwinula oblonga .

C-phase species are represented by one specimen of C. dorsispinata.

Faunicycle 69, Egerton. 195 specimens from $\mathrm{Ha}$ and $\mathrm{Wd}$.

S-phase species represent $20 \%$ of the fauna with darwinulids (10\%), $M$. henfieldensis (7\%), also $T$. fittoni and Mantelliana mantelli. M. mantelli and Miocytheridea henfieldensis are new arrivals.

C-phase species are $C$. dorsispinata (73\%), C. clavata and $C$. tuberculata. Cypridea clavata is present for the first time.

Faunicycle 70, Redhill. 814 specimens from Wd.

S-phase species represent $17 \%$ of the fauna and include darwinulids (9\%) with $M$. mantelli, $T$. fittoni and $M$. henfieldensis.

C-phase species are C. dorsispinata (50\%), C. tuberculata $(30 \%)$ and C. clavata.

Faunicycle 71, Hackhurst. 1041 specimens from $\mathrm{Ha}$, So and Wd.

S-phase species represent $22 \%$ of the fauna including $T$. fittoni (9\%), darwinulids (8\%), with $M$. henfieldensis, $M$. mantelli and $F$. boloniensis.

C-phase species are $C$. dorsispinata (59\%), with $C$. tuberculata and C. clavata.

Faunicycle 72, Marden. 2816 specimens from Ha, Re, $\mathrm{Wa}$ and $\mathrm{Wd}$.

S-phase species represent $23 \%$ of the fauna with darwinulids (13\%), T. fittoni (8\%), M. henfieldensis and M. mantelli.

C-phase species are C. dorsispinata (42\%), C. tuberculata $(31 \%)$ and $C$. clavata.

Faunicycle 73, Hailsham. 2217 specimens from $\mathrm{Ha}$, Re, $\mathrm{Wa}$ and Wd.

S-phase species represent $34 \%$ of the fauna with darwinulids (22\%), $M$. henfieldensis $(10 \%), T$. fittoni and $D$. pygmaea.

C-phase species are $C$. dorsispinata (50\%), with C. clavata, C. tuberculata, C. valdensis, and a new form Cypridea pumila. 
Faunicycle 74, Langhurst. 1532 specimens from $\mathrm{Ha}$ and Re.

S-phase species represent $22 \%$ of the fauna with darwinulids (12\%), $M$. henfieldensis (8\%), M. mantelli and $D$. pygmaea .

C-phase species are $C$. dorsispinata (72\%), with C. tuberculata, C. clavata and C. valdensis.

\begin{abstract}
ASSEMBLAGE 12
At the base of the higher part of the Lower Weald Clay (Henfield phase), there is again a marked faunal change. Only one of the subspecies of Cypridea dorsispinata i.e.roemeri lingers on and is never very common. The dominant $\mathbf{C}$-phase species is $C$. tuberculata, accompanied by $C$. pumila, C. marina and $C$. valdensis. In the S-phases, $M$. henfieldensis is the most abundant species. There appears to have been a steady decrease in salinity throughout this assemblage up to the Crawley Faunicycle.
\end{abstract}

Faunicycle 75, Henfield. 1226 specimens from $\mathrm{Ha}$, Re, So, Wa, Wd and Wm.

S-phase species represent $80 \%$ of the fauna and include $M$. henfieldensis (42\%), darwinulids (31\%), $T$. fittoni and $D$. pygmaea.

C-phase species are C. tuberculata $(10 \%), C$. pumila (7\%), C. clavata and C. valdensis.

Faunicycle 76, Rolvenden. 1935 specimens from $\mathrm{Ha}$, Re, So, Wa and Wm.

S-phase species represent $52 \%$ of the fauna including $M$. henfieldensis (42\%), with $T$. fittoni, Damonella buchaniana, D. pygmaea, $M$. mantelli and darwinulids.

C-phase species are $C$. pumila (38\%), with $C$. clavata, C. tuberculata, C. valdensis and C. dorsispinata roemeri.

Faunicycle 77, Edenbridge. 2983 specimens from Ha, $\mathrm{Re}$, So, Wa and Wm.

S-phase species represent $47 \%$ of the fauna with $M$. henfieldensis (26\%), T. fittoni, D. pygmaea, $M$. mantelli, $D$. buchaniana and darwinulids.

C-phase species are $C$. valdensis (19\%), C. pumila (11\%), $C$. tuberculata and two species appear, $C$. marina and $C$. brendae sp. nov. (see later).

Faunicycle 78, Sandhurst. 4855 specimens from $\mathrm{Cu}, \mathrm{Ha}$, $\mathrm{Re}, \mathrm{So}, \mathrm{Wa}$ and $\mathrm{Wm}$.

S-phase species represent $18 \%$ of the fauna and include $M$. henfieldensis $(9 \%)$, with $T$. fittoni, $D$. pygmaea, $M$. mantelli and darwinulids.

C-phase species are $C$. tuberculata (36\%), with $C$. clavata, $C$. dorsispinata roemeri, $C$. valdensis and $C$. marina.
Faunicycle 79, Crawley. 2548 specimens from $\mathrm{Cu}$, $\mathrm{Ha}$, $\mathrm{Re}$, So, Wa and Wm.

S-phase species represent $8 \%$ of the fauna and include $M$. henfieldensis (8\%) with $M$. mantelli, D. pygmaea, $T$. fittoni and darwinulids.

C-phase species include $C$. tuberculata (69\%), with $C$. clavata, C. valdensis, C. marina and C. brendae sp. nov.

Faunicycle 80, Fernhurst. 1547 specimens from $\mathrm{Cu}, \mathrm{Ha}$, $\mathrm{Re}$ and Wa.

S-phase species represent $15 \%$ of the fauna and include $M$. henfieldensis $(6 \%)$, with $M$. mantelli, $T$. fittoni, $D$. pygmaea and darwinulids.

C-phase species include $C$. pumila (37\%), C. tuberculata $(28 \%), C$. clavata, C. valdensis and C. brendae sp. nov.

Faunicycle 81, Plumpton. 1396 specimens from $\mathrm{CH}, \mathrm{Cu}$, $\mathrm{Ha}, \mathrm{Re}, \mathrm{Wa}$ and $\mathrm{Wm}$.

S-phase species represent $28 \%$ of the fauna including $M$. henfieldensis $(18 \%)$, with Cytheridea (Haplocytheridea) delicatula, $M$. mantelli and darwinulids.

C-phase species are $C$. pumila (41\%), C. clavata (20\%), C. tuberculata, C. valdensis and C. marina.

\section{ASSEMBLAGE 13}

Cypridea marina replaces $C$. pumila as the dominant C-phase species during this period. The S-phase fauna is little changed except that $T$. fittoni becomes more abundant. Note that Fabonella boloniensis is present in the more saline Buxted, Ockley and Ewhurst Faunicycles.

Faunicycle 82, Buxted. 1945 specimens from $\mathrm{CH}, \mathrm{Cu}$, $\mathrm{Ha}, \mathrm{Re}$ and Wa.

S-phase species represent $44 \%$ of the fauna, including $M$. henfieldensis (24\%), M. mantelli, D. pygmaea, $F$. boloniensis and darwinulids.

C-phase species are $C$. pumila $(40 \%), C$. valdensis (13\%), C. marina, C. tuberculata and C. clavata.

Faunicycle 83, Ockley. 1611 specimens from $\mathrm{CH}, \mathrm{Cu}$, $\mathrm{Ha}, \mathrm{Re}$ and Wa.

S-phase species represent $49 \%$ of the fauna with $M$. henfieldensis $(39 \%), M$. mantelli, $F$. boloniensis and darwinulids.

C-phase species are C. pumila (45\%), C. tuberculata, C. valdensis, C. clavata and C. marina.

Faunicycle 84, Horley. 2850 specimens from $\mathrm{CH}, \mathrm{Cu}$, $\mathrm{Ha}, \mathrm{Re}$ and Wa.

S-phase species represent $27 \%$ of the fauna with $M$. henfieldensis (12\%), T. fittoni, M. mantelli and darwinulids.

C-phase species are C. marina (58\%), C. tuberculata, C. pumila, C. valdensis and C. clavata. Cypridea hispida sp. nov. (see later) appears in this Faunicycle. 
Faunicycle 85, Slinfold. 4287 specimens from $\mathrm{CH}, \mathrm{Cu}$, $\mathrm{Ha}, \mathrm{Re}$ and Wa.

S-phase species represent $14 \%$ of the fauna with $T$. fittoni (5\%), M. henfieldensis (4\%), M. mantelli, $D$. pygmaea and darwinulids.

C-phase species are $C$. marina $(72 \%), C$. hispida, $C$. tuberculata, $C$. pumila and $C$. valdensis.

Faunicycle 86, Newdigate. 1906 specimens from $\mathrm{CH}$, $\mathrm{Ha}, \mathrm{Re}$ and Wa.

S-phase species represent $14 \%$ of the fauna with $T$. fittoni $(9 \%), M$. henfieldensis, $M$. mantelli and darwinulids.

C-phase species are $C$. marina (39\%), C. hispida (31\%), C. tuberculata, C. pumila, $C$. clavata and $C$. valdensis.

Faunicycle 87, Romney. 485 specimens from $\mathrm{CH}$, Ha and Wa.

S-phase species represent $50 \%$ of the fauna including $M$. henfieldensis (31\%), M. mantelli and darwinulids.

C-phase species are C. tuberculata $(27 \%), C$. clavata $(20 \%)$ and C. valdensis.

Faunicycle 88, Ewhurst. 1022 specimens from $\mathrm{CH}$ and Wa.

S-phase species represent $54 \%$ of the fauna with $M$. henfieldensis (22\%), Cytheridea (H.) delicatula (22\%), $M$. mantelli, Orthonotacythere diglypta and $F$. boloniensis.

C-phase species are C. clavata (39\%), C. tuberculata and $C$. valdensis.

\section{ASSEMBLAGE 14}

In the Upper Weald Clay, the $\mathbf{C}$-phase fauna is largely made up of $C$. clavata and its subspecies, with $C$. tuberculata and $C$. valdensis. Important species are $C$. bogdenensis which is typical of the Gillmans and Ditchling Faunicycles, and $C$. rotundata which is a common form in this assemblage. In the S-phases, $T$. fittoni eventually replaces $M$. henfieldensis as the dominant species. In the Atherfield and Woodhatch Faunicycles, there is a marked increase in salinity.

Faunicycle 89, Capel. 813 specimens from $\mathrm{CH}, \operatorname{Re}$ and Wa.

S-phase species represent $66 \%$ of the fauna and include $C$. (H.) delicatula (62\%), with $M$. henfieldensis and $O$. diglypta.

C-phase species are C. clavata (33\%), C. tuberculata and $C$. valdensis.

Faunicycle 90, Bonnington. 94 specimens from $\mathrm{CH}$ and Wa.

S-phase species represent $37 \%$ of the fauna with $M$. henfieldensis $(28 \%), M$. mantelli, D. pygmaea and C. (H.) delicatula.

C-phase species are $C$. tuberculata (50\%) and $C$. clavata (13\%).
Faunicycle 91, Pluckley. 127 specimens from Wa.

S-phase species represent $37 \%$ of the fauna with Damonella pygmaea (15\%), Darwinula oblonga (14\%), $T$. fittoni $(\mathbf{7 \%})$ and $M$. henfieldensis.

C-phase species include $C$. tuberculata $(37 \%)$. C. rotundata appears and makes up $17 \%$ of the fauna and C. valdensis $(9 \%)$.

Faunicycle 92, Gillmans. 3273 specimens from Re and Wa.

S-phase species present $15 \%$ of the fauna and include $T$. fittoni (11\%), D. pygmaea, $M$. henfieldensis, $M$. mantelli, $R$. jurassica and darwinulids.

C-phase species are $C$. clavata (32\%), C. bogdenensis (22\%), C. valdensis (16\%), C. rotundata $(14 \%), C$. fasciata and $C$. tenuis. Cypridea bogdenensis, $C$. fasciata and $C$. tenuis are all forms first seen in this Faunicycle.

Faunicycle 93, Ditchling. 1696 specimens from Re and Wa.

S-phase species represent $17 \%$ of the fauna with $T$. fittoni (16\%), M. mantelli, $M$. henfieldensis and darwinulids.

C-phase species are $C$. clavata $(27 \%), C$. rotundata (21\%), C. bogdenensis (18\%), C. valdensis (16\%), C. fasciata, $C$. hamata and $C$. spinigera. The last two species are first seen in this Faunicycle.

Faunicycle 94, Atherfield. 569 specimens from $\operatorname{Re}$ and Wa.

S-phase species represent $62 \%$ of the fauna with $T$. fittoni $(58 \%), M$. mantelli, $M$. henfieldensis and darwinulids.

C-phase species are $C$. valdensis $(28 \%), C$. hamata (9\%), and the first occurrence of $C$. insulae, $C$. caudata and $C$. comptonensis.

Faunicycle 95, Woodhatch. 1030 specimens from $R e$ and Wa.

S-phase species represent $80 \%$ of the fauna with $T$. fittoni, M. mantelli and Darwinula jonesi.

C-phase species are C. valdensis $(10 \%), C$. comptonensis, $C$. tenuis and three new first occurrences, $C$. cuckmerensis, $C$. vectae and $C$. warlinghamensis.

\section{ASSEMBLAGE 15}

In the highest part of the Weald Clay and the transition beds to the Lower Greensand, the salinity was high throughout. Cypridea spinigera is a typical $\mathbf{C}$-phase species and Theriosynoecum fittoni is by far the most abundant ostracod.

Faunicycle 96, Sandown. 720 specimens from At, Re and $\mathrm{Wa}$.

S-phase species represent $75 \%$ of the fauna and include $T$. fittoni (74\%), with $M$. mantelli and Sternbergella cornigera (a new form).

C-phase species are $C$. spinigera $(14 \%), C$. fasciata, $C$. hamata, $C$. valdensis, $C$. tenuis, $C$. warlinghamensis, C. rotundata, C. caudata and C. cuckmerensis. 
Faunicycle 97, Cuckmere. 774 specimens from At, Re and Wa.

S-phase species represent $75 \%$ of the fauna with $T$. fittoni $(74 \%), D$. leguminella, $S$. cornigera and $M$. mantelli.

C-phase species are $C$. valdensis $(18 \%), C$. warlinghamensis, C. hamata, C. spinigera, C. insulae, C. tenuis, C. clavata, $C$. rotundata and $C$. cuckmerensis.

Faunicycle 98, Earlswood. 906 specimens from At and Re.

S-phase species represent $95 \%$ of the fauna with $T$. fittoni $(83 \%), M$. mantelli, D. oblonga and $S$. cornigera .

C-phase species are $C$. tenuis $(4 \%), C$. fasciata, $C$. rotundata, $C$. warlinghamensis, $C$. cuckmerensis and C. spinigera.

\section{NOTES ON THE SPECIES}

Stratigraphically important species are marked, on the following pages, with an asterisk (*, see Fig. 5). The percentages given are of the total number of specimens of the species that have been collected. The occurrences of species of Cypridea are shown on Fig. 3 and of the other genera on Fig. 4. Notes on the other genera follow those on Cypridea on p. 33.

Suborder Podocopina Sars, 1866

Family Ilyocyprididae Kaufman, 1900

Genus Cypridea Bosquet, 1852

${ }^{*}$ Cypridea aculeata Jones, 1885

Material. 3076 specimens from $\mathrm{Co}, \mathrm{FL}, \mathrm{Gl}, \mathrm{Gu}, \mathrm{He}, \mathrm{Ki}$, LM, NP, Po, PQ, Sh, Wa, We, WP.

Range. Kingsclere to Grinstead Faunicycles, Wadhurst Clay. A few similar forms ( $C$. aff. aculeata) which are found in the lower part of the Wadhurst Clay and in the Upper Tunbridge Wells Sand may belong to this species - giving a total range of Winchester to Salehurst Faunicycles.

Maximum. Hawkhurst Faunicycle, 56\%. The species first becomes important in the Fairlight Faunicycle and is abundant in the Lindfield, Wadhurst, Crowhurst, Hawkhurst and Fletching Faunicycles.

Subspecies aculeata Jones, 1885

Hawkhurst to Grinstead Faunicycles (Pl. 6, fig. 9)

Subspecies antiqua Anderson, 1967

Wadhurst to Crowhurst Faunicycles (P1. 6, fig. 8)

Subspecies elgivae Anderson, 1967

Fairlight to Lindfield Faunicycles

(Pl. 6, fig. 11)

Subspecies eppili Anderson, 1967

Crowhurst to Chilcombe Faunicycles (Pl. 6, fig. 3)

Subspecies eustacii Anderson, 1967

St. Leonards to Linfield Faunicycles

(Pl. 6, fig. 5)

Subspecies holmani Anderson, 1967

Hawkhurst to Chilcombe Faunicycles

(P1. 7, fig. 1)
Subspecies plautii Anderson, 1967

St. Leonards to Fairlight Faunicycles (P1. 7, fig. 2)

Subspecies regni Anderson, 1967

Hawkhurst to Chilcombe Faunicycles

(P1. 7, fig. 4)

Subspecies subaculeata Anderson, 1967

Hawkhurst to Chilcombe Faunicycles

(P1. 7, fig. 7)

Cypridea aemulans, new name for $C$. acuta Anderson (1971b; p. 50, pl. xvi, fig. 5) preoccupied by $C$. acuta Moos (1959 p. 46). (An inverse species).

(Pl. 4, fig. 2)

Material. 1333 specimens from $\mathrm{Bg}, \mathrm{Br}, \mathrm{CD}, \mathrm{DB}, \mathrm{Fa}, \mathrm{GS}$, $\mathrm{Cu}, \mathrm{He}, \mathrm{Ki}, \mathrm{Mo}, \mathrm{MW}, \mathrm{NP}, \mathrm{Pe}, \mathrm{Po}$, Wa.

Range. Corfe to Nutfield Faunicycles. Fairly common in the Middle and Upper Purbeck. A similar form is occasionally seen in the Netherfield to Royal Faunicycles and may be this species.

Maximum. Battle Faunicycle 37\%.

${ }^{*}$ Cypridea alta Wolburg, 1959

Material. 1992 specimens from $\mathrm{Bg}, \mathrm{Br}, \mathrm{CD}, \mathrm{DB}, \mathrm{Fa}, \mathrm{Cu}$, Hd, Mo, NP, Wa.

Range. Greenwood to Battle Faunicycles (Upper Purbeck) but there are similar forms in the Scallop, Bacon, Bexhill and Eastbourne Faunicycles.

Maximum. Tisbury Faunicycle, 26\%.

Subspecies alta Wolburg, 1959

Maximum in Durdle Faunicycle (Pl. 5, fig. 14)

Subspecies formosa Wolburg, 1959

Maximum in Tisbury Faunicycle

(Pl. 5, fig. 13)

${ }^{*}$ Cypridea altissima Martin, 1940

(Pl. 5, fig. 18)

Material. 404 specimens from As, Bg, Br, Bs, CD, DB, $\mathrm{Fa}, \mathrm{Gu}, \mathrm{Hd}$, Mo, NP, Wa.

Range. Cinder Beds to Greenwood Faunicycles (Middle and Upper Purbeck).

Maximum. Langton Faunicycle, 22\%. It is possible that this form may be an unornamented subspecies of $C$. granulosa.

\section{*Cypridea amisia Wolburg, 1959}

$$
\text { (PI. 5, fig. 10) }
$$

Material. 1326 specimens from $\mathrm{Bg}, \mathrm{Br}, \mathrm{CD}, \mathrm{DB}, \mathrm{Fa}, \mathrm{Gu}$, Hd, Mo, MW, Pe, Po, Pt, Wa.

Range. Nothe to Bacon Faunicycles (Middle Purbeck). Maximum. Scallop Faunicycle, 36\%.

\section{Cypridea andersoni Wolburg, 1959}

(Pl. 5, fig. 7)

Material. 145 specimens from $\mathrm{Br}, \mathrm{CD}, \mathrm{Fa}, \mathrm{Mo}, \mathrm{Wa}$. Range. Langton to Tisbury Faunicycles (Upper Purbeck). Maximum. Tisbury Faunicycle, 50\%. 
Cypridea arenosa Anderson, 1967

Material. 764 specimens from CD, Co, FL, Gl, LM, Wa, We, WP.

Range. Fairlight to Hawkhurst Faunicycles (Wadhurst Clay).

Maximum. Lindfield Faunicycle, $41 \%$.

Subspecies arenosa Anderson, 1967

Fairlight and Linfield Faunicycles

(P1. 8, fig. 14)

Subspecies hengisti Anderson, 1967

Fairlight and Hawkhurst Faunicycles

(Pl. 9, fig. 1)

Subspecies marshalli Anderson, 1967

Fairlight and Lindfield Faunicycles

(Pl. 9, fig. 2)

Cypridea asseri Anderson, 1967

(An inverse species)

(Pl. 9, fig. 4)

Material. 362 specimens from Co, FL, Gl, Ki, Wa, We, WP.

Range. Fairlight to Hawkhurst Faunicycles (Wadhurst Clay).

Maximum. Hawkhurst Faunicycle, 64\%.

Cypridea bimammata Harbort, 1907

(An inverse species)

Material. 155 specimens from $\mathrm{Br}, \mathrm{CD}, \mathrm{Fa}, \mathrm{Gu}, \mathrm{Ki}, \mathrm{Mo}$, MW, Wa.

Range. Scallop to Hastings Faunicycles. (Middle and Upper Purbeck).

Maximum. Mupes Faunicycle, $43 \%$.

Subspecies bimammata Harbort, 1907

Range as for species (not figured)

Subspecies prolifera Anderson, 1971

Range as for species

(Pl. 6, fig. 15)

${ }^{*}$ Cypridea bispinosa Jones, 1878

(An inverse species)

Material. 3628 specimens from $\mathrm{Ba}, \mathrm{CD}, \mathrm{Co}, \mathrm{CL}, \mathrm{EG}$, FL, Gl, HC, HP, JL, Ki, LM, PQ, Sb, Se, SF, Sh, Wa, We, WP.

Range. Kingsclere to Cuckfield Faunicycles (Wadhurst Clay-Tunbridge Wells Sand).

Maximum. Hawkhurst Faunicycle, 36\%.

Subspecies birini Anderson, 1967

Middle Wadhurst Clay

(Pl. 7, fig. 13)

Subspecies bispinosa Jones, 1878

Upper Wadhurst Clay to Tunbridge Wells Sand

(Pl. 7, fig. 17)

Subspecies suthrigensis Anderson, 1967

Middle Wadhurst Clay

(Pl. 7, fig. 10)

${ }^{*}$ Cypridea blackbushensis Anderson, 1967

(An inverse species)

(P1. 8, fig. 2)

Material. 1214 specimens from $\mathrm{Bl}, \mathrm{CD}, \mathrm{Gl}, \mathrm{Ki}, \mathrm{LM}, \mathrm{Wa}$, We, WP.
Range. Rye to Hawkhurst Faunicycles (Wadhurst Clay). Maximum. Rye Faunicycle, 62\%.

*Cypridea bogdenensis Anderson, 1967

(An inverse species)

(Pl. 10, fig. 10)

Material. 1023 specimens from Bo, GP, Re, Wa.

Range. Limited, Gillmans to Ditchling Faunicycles (Upper Weald Clay).

Maximum. Gillmans Faunicycle, 71\%.

* Cypridea brendae sp. nov.

(PI. 10, fig. 5)

Derivation of name. After Brenda Coleman (ex B.G.S) who took the SEM photographs for this paper.

Holotype. B.G.S. Mik (M) 4485 .

Dimensions. Holotype length $0.85 \mathrm{~mm}$, height $0.51 \mathrm{~mm}$. Locality and horizon. Cuckfield No. 2 Borehole, Sussex, at $89-90 \mathrm{ft} \quad(27.12-27.43 \mathrm{~m})$. Crawley Faunicycle, Henfield phase of the Lower Weald Clay, Cypridea tuberculata Zone.

Diagnosis. A medium sized carapace, triangular ovate in lateral view. Rostrum large, alveolus long and deep, cyathus lunate. Surface covered with fine punctations. Ornament consisting of 2-4, generally 3 , large spines in the furcal area and a number of very small auxiliary tubercles in the anterodorsal area and a few in the posterodorsal area. The left valve is the larger.

Description. This species is probably related to Cypridea marina with which it is usually associated, but the spinose ornament is much sparser and quite distinctive. Notably the polar and ocular tubercles seen in C. marina are always absent.

Distribution. This is a stratigraphically important species so far known only from the Edenbridge to Fernburst Faunicycles of the Lower Weald Clay. It has been found in the Cuckfield No. 2 Borehole $(\mathrm{Cu})$, the Hailsham Borehole (Ha), the Pevensey No. 2 Borehole (Py), the Ripe Borehole ( $R e$ ), the Warlingham Borehole (Wa) and Warnham Brick Pit (Wm).

\section{*Cypridea brevirostrata Martin, 1940 \\ (An inverse species)}

(PI. 5, fig. 16)

Material. 594 specimens from $\mathrm{Bg}, \mathrm{Br}, \mathrm{CD}, \mathrm{DB}, \mathrm{Fa}, \mathrm{He}$, $\mathrm{Ki}$, Mo, OM, Po, Wa, WB.

Range. Scallop to Eastbourne Faunicycles (Middle Purbeck and Ashdown Beds).

Maximum. Bexhill Faunicycle, 38\%.

\section{Cypridea caudata Anderson, 1967}

$$
\text { (Pl. 10, fig. 15) }
$$

Remarks. A rare species in the Upper Weald Clay (Atherfield to Sandown Faunicycles) found at Atherfield, Bletchingly Tunnel and possibly in the Punfield Beds, but the range is not well known. 
* Cypridea clavata Anderson, 1939 (An inverse species) Material. 4192 specimens from BM, CH, Cu, EF, Ha, $\mathrm{He}$, PS, Py, Re, So, ST, Wa, Wd, Wm, Ya.

Range. Egerton to Cuckmere Faunicycles (Weald Clay). Maximum. Gillmans Faunicycle, 25\%.

Subspecies bardana Anderson, 1967

Maximum in Gillmans Faunicycle

(P1. 9, fig. 17)

Subspecies beltana Anderson, 1967

Maximum in Ditchling Faunicycle

(Pl. 9, fig. 18)

Subspecies clavata Anderson, 1939 Mainly Lower Weald Clay

(P1. 9, fig. 15)

Subspecies gordana Anderson, 1967

Maximum in Gillmans Faunicycle

(P1. 10, fig. 16)

Subspecies maleta Anderson, 1967

Maximum in Gillmans Faunicycle

(Pl. 10, fig. 1)

†Subspecies mistrata Anderson, 1967

Maximum in Gillmans Faunicycle

(P1. 10, fig. 2)

†Subspecies talaria Anderson, 1967

Maximum in Gillmans Faunicycle

(Pl. 10, fig. 3)

Cypridea coelnothi Anderson, 1971

(P1. 4, fig. 8)

Material. 598 specimens from Br, Fa, GD, Hd, He, HW, Mo, MW, NP, NW.

Range. Goldspur to Peveril Faunicycles (Middle Purbeck).

Maxima. Durlston Faunicycle, 50\%; Netherfield Faunicycle, $41 \%$.

\section{${ }^{*}$ Cypridea comptonensis Anderson, 1967}

(Pl. 10, fig. 18)

Material. 47 specimens from CC, Rd, Re, SC.

Range. Atherfield to Woodhatch Faunicycles (Upper Weald Clay).

Maximum. Atherfield Faunicycle. This is a rare but important species of very limited range.

\section{Cypridea cuckmerensis Anderson, 1967}

(Pl. 11, fig. 4)

Remarks. Only a few specimens known from At, CB, $\mathrm{Ea}, \mathrm{Wa}$. This species has only been found in the highest beds of the Weald Clay: Woodhatch to Earlswood Faunicycles.

\section{Cypridea darvelensis Anderson, 1971}

(An inverse species)

(Pl. 5, fig. 11)

Material. 265 specimens known from $\mathrm{Bg}, \mathrm{Br}, \mathrm{CD}, \mathrm{DB}$, $\mathrm{Fa}, \mathrm{He}$, Mo, Wa.

Range. Worth to Mupes Faunicycles (Middle and Upper Purbeck).

Maximum. Bacon Faunicycle, $41 \%$.
Cypridea delicatula Anderson, 1971 (An invese species) (P1. 4, fig. 7)

Material. 624 specimens from $\mathrm{Bg}, \mathrm{Br}, \mathrm{DB}, \mathrm{Fa}, \mathrm{GD}, \mathrm{Gu}$, $\mathrm{He}, \mathrm{Ki}, \mathrm{Mo}, \mathrm{MW}, \mathrm{NP}, \mathrm{NW}$, Wa.

Range. Goldspur to Peveril Faunicycles (Middle Purbeck).

Maximum. Ashdown Faunicycle, 50\%.

* Cypridea dolabrata (Anderson, 1939)

Material. 194 specimens from $\mathrm{Br}, \mathrm{CD}, \mathrm{DB}, \mathrm{Fa}, \mathrm{Hd}, \mathrm{He}$, $\mathrm{Ki}$, Mo, Pe, Po, Wa.

Range. Scallop to Hythe Faunicycles (Middle PurbeckAshdown Sands), includes C. dolabrata sensu lato.

Maximum. Tyneham Faunicycle, 42\% (C. dolabrata angulata).

Subspecies angulata Martin, 1940

Brede to Tyneham Faunicycles

(Pl. 4, figs. 14, 18)

Subspecies dolabrata (Anderson, 1939)

Eastbourne Faunicycle

(Pl. 4, fig. 16)

Subspecies kingsclerensis Anderson, 1971

Tisbury to Bexhill Faunicycles

(Pl. 12, fig. 19)

${ }^{*}$ Cypridea dorsispinata (Anderson, 1939)

Material. 5281 specimens from $\mathrm{CH}, \mathrm{Cu}, \mathrm{Ha}, \mathrm{He}, \mathrm{Re}$, So, Wa, Wd, Wm.

Range. Sevenoaks to Sandhurst Faunicycles (Lower Weald Clay).

Maximum. Hailsham Faunicycle, 40\%.

An important species nearly limited to the basal beds of the Weald Clay (Assemblage 11) in which it is the dominant form, only the subspecies roemeri continues upwards into the Henfield phase - into Assemblage 12.

Subspecies dorsispinata (Anderson, 1939)

Maximum in Redhill Faunicycle

(Pl. 9, fig. 7)

Subspecies duplicata Anderson, 1967

A rare form

(P1. 9, fig. 8)

Subspecies gemella Anderson, 1967

$A$ rare form

(Pl. 9, fig. 9)

Subspecies quinquecornis Anderson, 1967

A very rare form

(Pl. 9, fig. 10)

Subspecies roemeri (Anderson, 1939)

Maximum in Hailsham Faunicycle

(Pl. 9, fig. 16)

Subspecies tricornis Anderson, 1967

A common subspecies in the Horsham phase

(PI. 9, fig. 11)

†In Anderson, 1967, pp. 240-241 and 262, the figure numbers were inadvertently transposed so that fig. 31 should be $C$. clavata talaria and fig. 32 C. clavata mistrata. H.I-C. 
Cypridea dunkeri Jones, 1885 (An inverse species)

Material. 4239 specimens from $\mathrm{As}, \mathrm{Ay}, \mathrm{Bg}, \mathrm{Br}, \mathrm{CD}, \mathrm{DB}$, DR, Fa, GD, Gu, He, Ki, MA, MB, Mo, Nd, NP, OM, PC, PU, Ri, Sw, Wa.

Range. Quainton to Peveril Faunicycles.

Maximum. Hard Cockle Faunicycle.

This is a typical C-phase species in the Lower and lower part of the Middle Purbeck.

Subspecies carinata Martin, 1940

Ringstead to Ashdown Faunicycles, maximum in the Mountfield Faunicycle

(Pl. 1, fig. 10)

Subspecies dunkeri Jones, 1855

Swanage to Peveril Faunicycles, maximum in the Swanage and Netherfield Faunicycles

(Pl. 1, fig. 8)

Subspecies inversa Martin, 1940

Swindon to Upper Soft Cockle Faunicycles, maximum in the Hard Cockle Faunicycles

(Pl. 1, fig. 18)

Subspecies papulata (Anderson, 1941)

Quainton to Stair Faunicycles, rare earliest subspecies (Pl. 1, fig. 11)

\section{Cypridea fasciata Anderson, 1967}

(Pl. 10, fig. 8)

Material. A rare species from At, HB, Hn, Re.

Range. Gillmans to Earlswood Faunicycles (Upper Weald Clay).

Maximum. Sandown Faunicycle.

Cypridea frithwaldi Anderson, 1967

(An inverse species)

(Pl. 8, fig. 3)

Material. 355 specimens from CD, Co, FL, Gl, Ki, LM, Wa, We, WP.

Range. Kingsclere to Fletching Faunicycles (Upper Wadhurst Clay).

Maximum. Hawkhurst Faunicycle, $44 \%$.

\section{Cypridea giffordi Anderson, 1967}

$$
\text { (P1. 9, fig. 3) }
$$

Material. 111 specimens from Co, FL, Gl, LM, Wa, We, WP.

Range. Fairlight to Hawkhurst Faunicycles (mainly Upper Wadhurst Clay).

Maximum. Fairlight Faunicycle, 43\%.

* Cypridea granulosa (J. de C. Sowerby, 1836)

Material. 16,169 specimens from $\mathrm{As}, \mathrm{Bg}, \mathrm{Br}, \mathrm{CD}, \mathrm{DB}$, $\mathrm{Fa}, \mathrm{GD}, \mathrm{Gu}, \mathrm{He}, \mathrm{Ki}, \mathrm{MB}, \mathrm{Mo}, \mathrm{NP}, \mathrm{Pe}, \mathrm{Po}, \mathrm{Ri}, \mathrm{VW}$, Wa.

Range. Lower Soft Cockle to Langton Faunicycles (Lower and Middle Purbeck).

Maximum. Peveril Faunicycle, 18\%.
This is the most important and typical species in the Middle Purbeck.

Subspecies fasciculata (Forbes, 1855)

Ranges from Netherfield to Langton Faunicycles. Maximum in Peveril Faunicycle.

(P1. 3. fig. 18 with footnote H.I-C)

Subspecies granulosa (J. de C. Sowerby, 1836)

Ranges from Burwash to Corfe Faunicycles. Maximum in Netherfield Faunicycle.

(Pl. 3, fig. 8)

Subspecies protogranulosa Anderson, 1971

Ranges from the Lower Soft Cockle to the Nothe Faunicycles. Maximum in the Goldspur Faunicycle.

(P1. 3, fig. 12)

Cypridea hamata Anderson, 1967

(Pl. 10, fig. 12)

Material. 92 specimens from Ar, At, Rd, Wa.

Range. Ditchling to Cuckmere Faunicycles (Upper Weald Clay).

Maximum. Woodhatch Faunicycle, 56\%. A rare species.

\section{Cypridea helenae Anderson, 1967}

(An inverse species)

(Pl. 8, fig. 11)

Material. 127 specimens from LM, Wa, We, WP.

Range. St. Leonards to Hawkhurst Faunicycles (middle part of the Wadhurst Clay).

Maximum. Crowhurst Faunicycle, 48\%.

\section{${ }^{*}$ Cypridea hispida sp. nov.}

(PI. 10, fig. 6)

Derivation of name. Latin hispidus, $-a,-u m$; prickly.

Holotype. B.G.S. Mik (M) 4486.

Dimensions. Holotype length $0.72 \mathrm{~mm}$, height $0.43 \mathrm{~mm}$. Locality and horizon. Hailsham Borehole, Sussex, at $19.00-19.50 \mathrm{~m}$. Slinfold Faunicycle, Henfield phase of the Lower Weald Clay, C. marina Zone.

Diagnosis. A medium sized carapace with a large rostrum and alveolus. Cyathus narrow, lunate. Surface rather coarsely punctate in the centre becoming finer towards the margins. The ornament consists of generally 2 or 3 large tubercles in the furcal area and a large ocular. A lumbar tubercle may be present at the dorsal end of the furcal row. The left valve is the larger.

Description. This appears to be related to Cypridea marina, but with much reduced ornament and a more limited stratigraphical distribution. There are usually a number of small auxiliary tubercles particularly near the anterior end but sometimes also in the lumbar area.

Distribution. $C$. hispida has been found in the Horley, Slinfold and Newdigate Faunicycles of the Lower Weald Clay (Henfield phase) in the Clock House Brick Pit $(\mathrm{CH})$, the Hailsham Borehole (Ha), the Pevensey No. 8 Borehole (Py), the Ripe Borehole ( $\mathrm{Re}$ ) and the Warlingham Borehole (Wa).

Because of its limited vertical range this species is a useful stratigraphical index. 
Cypridea inaequalis Wolburg, 1959

(Pl. 4, fig. 11)

Material. 107 specimens from $\mathrm{As}, \mathrm{Br}, \mathrm{CD}, \mathrm{Fa}, \mathrm{GS}, \mathrm{Ki}$, Mo, Pe, Pt.

Range. Corfe to Tisbury Faunicycles (Middle and Upper Purbeck).

Maximum. Tisbury Faunicycle, 66\%.

\section{Cypridea insulae Anderson, 1967}

(Pl. 10, fig. 14)

Material. A few specimens only from SB, SC.

Remarks. This is a rare species known only from the Upper Weald Clay at Sandown and Shepherd's Chine in the Isle of Wight.

\section{${ }^{*}$ Cypridea laevigata (Dunker, 1846)}

Material. 3155 specimens from CD, Co, DB, FL, Gl, $\mathrm{He}, \mathrm{Ki}, \mathrm{LM}, \mathrm{PQ}, \mathrm{St}, \mathrm{Ti}, \mathrm{Wa}, \mathrm{We}$, WP.

Range. Mupes to Cuckfield Faunicycles (Upper PurbeckTunbridge Wells Sand).

Maximum. Kingsclere Faunicycle, $31 \%$. $77 \%$ of all specimens were found in the Kingsclere, St. Leonards and Fairlight Faunicycles (Nos. 51-53).

A few specimens of $C$. laevigata are found in the Upper Purbeck but the species first becomes important at the base of the Wadhurst Clay (Rye Faunicycle) as the subspecies laevigata. It becomes the dominant species in the Kingsclere Faunicycle (leonardi subspecies). The subspecies subquadrata and fairlightensis are typical forms in the St. Leonards and Fairlight Faunicycles. The species is not very common in the Lindfield, Wadhurst and Crowhurst Faunicycles where wadhurstensis is the characteristic subspecies, but becomes abundant again in the Hawkhurst Faunicycle (subspecies hawkhurstensis). At higher levels, mainly in the Grinstead Faunicycle, the subspecies is philpottsi but this is never very common. Specimens of $C$. aff. laevigata occur rarely in Assemblage 10.

Subspecies fairlightensis Anderson, 1967

Fairlight Faunicycle only

(Pl. 7, fig. 9)

Subspecies hawkhurstensis Anderson, 1967

Crowhurst to Fletching Faunicycles, maximum in the Hawkhurst Faunicycle

(P1. 7, fig. 12)

Subspecies laevigata (Dunker, 1846)

Mupes to Lydd Faunicyles, maximum in the Rye Faunicycle

(Pl. 7, fig. 3)

Subspecies leonardi Anderson, 1967

Kingsclere to St. Leonards Faunicycles, maximum in the Kingsclere Faunicycle

(PI. 7, fig. 8)

Subspecies philpottsi Anderson, 1967

Grinstead Faunicycle

(Pl. 7, fig. 5)

Subspecies subquadrata Anderson, 1967

St. Leonards Faunicycle

(Pl. 7, fig. 16)
Subspecies wadhurstensis Anderson, 1967, Wadhurst to Crowhurst Faunicycles

(Pl. 7, fig. 6)

Cypridea lasius Anderson, 1967

(Pl. 8, fig. 10)

Material. 152 specimens from $\mathrm{CD}, \mathrm{Co}, \mathrm{Gl}$, We, WP. Range. Kingsclere to Highbridge Faunicycles (Wadhurst Clay).

Maximum. St. Leonards Faunicycle, 50\%.

* Cypridea lata Martin, 1940

Material. 2900 specimens from $\mathrm{As}, \mathrm{Bg}, \mathrm{Br}, \mathrm{BW}, \mathrm{CD}$, DB, DM, Fa, GD, GS, Gu, He, HW, Ki, Mo, MW, NP, NW, Pe, Po, Py, Wa.

Range. Mountfield to Brede Faunicycles (Middle and Upper Purbeck).

Maximum. Durlston Faunicycle, 19\%.

An important and widespread species particularly in the Middle Purbeck.

Subspecies lata Martin, 1940

Netherfield to Cinder Beds Faunicycles, maximum in the Durlston Faunicycle

(PI. 3, fig. 14)

Subspecies latissima Anderson, 1971

Poxwell to Brede Faunicycles, maximum in the Mupes Faunicycle

(Pl. 3, fig. 15)

Subspecies senilis Anderson, 1971

Royal to Poxwell Faunicycles, maximum in the Scallop Faunicycle

(Pl. 3, fig. 17)

${ }^{*}$ Cypridea marina Anderson, 1967

(Pl. 10, fig. 17)

Material. 6619 specimens from $\mathrm{BG}, \mathrm{CH}, \mathrm{Cu}, \mathrm{FF}, \mathrm{Ha}$, Py, Re, Ru, So, TB, Wa, Wm.

Range. Edenbridge to Newdigate Faunicycles (Lower Weald Clay).

Maximum. Slinfold Faunicycle, 47\%.

This is a species characteristic of the Henfield phase of the Lower Weald Clay.

\section{Cypridea martini Wolburg, 1959}

(Pl. 11, fig. 14)

Material. 37 specimens from $\mathrm{Br}, \mathrm{Fa}, \mathrm{Hd}, \mathrm{MW}$, Wa.

Range. Langton to Bacon Faunicycles (Middle Purbeck).

Maximum. Scallop Faunicycle, a rare species.

*Cypridea melvillei Anderson, 1967

(Pl. 8, fig. 8)

Material. 5334 specimens from $\mathrm{CD}, \mathrm{CL}, \mathrm{Co}, \mathrm{FL}, \mathrm{Ge}$, HC, HP, Ki, LM, PQ, Wa, We, WP.

Range. Bexhill to Salehurst Faunicycles (Ashdown Sand to Upper Tunbridge Wells Sand).

Maximum. Hawkhurst Faunicycle, 64\%. 
${ }^{*}$ Cypridea menevensis (Anderson, 1939)

(An inverse species)

(Pl. 7, fig. 11)

Material. 1104 specimens from CD, Co, Gl, He, Ki, LM, Po, Wa, We, WP.

Range. Hastings to Wadhurst Faunicycles (Ashdown Sand and Wadhurst Clay).

Maxima. St. Leonards and Fairlight Faunicycles, $62 \%$.

A species typical of the Wadhurst Clay but not easily distinguished from the Purbeck species $C$. penshurstensis.

*Cypridea morula Anderson, 1971

(Pl. 8, fig. 16)

Material. Specimens from CD.

Remarks. This is a rare but distinctive species so far known only from the Bexhill and Eastbourne Faunicycles in the Chilcomb Down Borehole, Hampshire.

\section{Cypridea obliqua Wolburg, 1959}

(PI. 5, fig. 15)

Material. 32 specimens from $\mathrm{As}, \mathrm{Bg}, \mathrm{CD}, \mathrm{DB}, \mathrm{Cu}, \mathrm{Ki}$, MW, Pe, Po, Pt, Wa.

Range. Langton to Bacon Faunicycles (Middle and Upper Purbeck).

Maximum. Scallop Faunicycle, 78\%.

\section{Cypridea parallela Martin, 1940}

(PI. 11, fig. 15)

Materials. Specimens from CD, He, Mo, Po, Wa.

Remarks. A rare species only seen in the Mupes and Brede Faunicycles of the Upper Purbeck.

${ }^{*}$ Cypridea paulsgrovensis (Anderson, 1939)

(An inverse species)

(Pl. 7, fig. 14)

Material. 7678 specimens from CD, Co, Gl, Ki, LM, Po, Wa, We, WP.

Range. Hastings to Fletching Faunicycles (Ashdown Sand-Wadhurst Clay).

Maximum. Winchester Faunicycle, 22\%.

This is a typical and abundant Wadhurst Clay species, closely resembling C. aemulans of the Middle and Upper Purbeck Beds and Ashdown Sand.

${ }^{*}$ Cypridea peltoides Anderson, 1971

Material. 3670 specimens from $\mathrm{As}, \mathrm{Bg}, \mathrm{Br}, \mathrm{Bt}, \mathrm{CD}, \mathrm{DB}$, DR, Fa, GD, Gu, Hd, He, Ki, MA, Mo, NP, NW, Wa.

Range. Hard Cockle to Langton Faunicycles (Lower and Middle Purbeck).

Maximum. Burwash Faunicycle, 36\%.

Subspecies eurygaster Anderson, 1971

Upper Soft Cockle to Swanage Faunicycles, maximum in Burwash Faunicycle

$$
\text { (Pl. 2, fig. 16) }
$$

Subspecies peltoides Anderson, 1971

Hard Cockle to Nothe Faunicycles, maximum in Goldspur Faunicycle

(Pl. 2, fig. 11)

\section{Cypridea pendae Anderson, 1967}

(Pl. 8, fig. 13)

Material. 673 specimens from Co, FL, Gl, JL, Ki, LM, PQ, Wa, We, WP.

Range. St. Leonards to Chilcombe Faunicycles (mainly Upper Wadhurst Clay).

Maximum. Hawkhurst Faunicycle, $42 \%$.

This species could possibly be an unornamented form of $C$. aculeata.

\section{*Cypridea penshurstensis Anderson, 1971 \\ (An inverse species)}

(Pl. 4, fig. 13)

Material. 3093 specimens from $\mathrm{Bg}, \mathrm{Br}, \mathrm{BW}, \mathrm{CD}, \mathrm{DB}$, $\mathrm{Fa}, \mathrm{GS}, \mathrm{Gu}, \mathrm{He}, \mathrm{Ki}, \mathrm{Mo}, \mathrm{NP}, \mathrm{Pe}, \mathrm{Po}$, Wa.

Range. Netherfield to Battle Faunicycles (Middle and Upper Purbeck).

Maximum. Lulworth Faunicycle, 27\%.

This species is rare until the Langton Faunicycle, is common in the Greenwood and Lulworth Faunicycles. Remarks. $C$. penshurstensis is very like $C$. menevensis and may be an ancestor of that species.

*Cypridea posticalis Jones, 1885

(Pl. 4, fig. 10)

Material. 690 specimens from $\mathrm{Ar}, \mathrm{Br}, \mathrm{CD}, \mathrm{DB}, \mathrm{Fa}, \mathrm{GD}$, $\mathrm{Hd}, \mathrm{He}, \mathrm{Ki}, \mathrm{Mo}, \mathrm{MW}, \mathrm{NP}, \mathrm{NW}, \mathrm{PC}, \mathrm{Pe}, \mathrm{Ri}, \mathrm{VW}$, Wa. Range. Netherfield and Durlston Faunicycles, possible specimens in Swanage Faunicycle.

Maximum. Durlston Faunicycle, 78\%.

Though not very abundant, this is a stratigraphically important species. It is widely distributed and short ranging.

\section{Cypridea primaeva Anderson, 1941}

(Pl. 2, fig. 12)

Material. 617 specimens from $\mathrm{As}, \mathrm{Ay}, \mathrm{Bg}, \mathrm{CD}, \mathrm{DB}, \mathrm{Fa}$, GD, Gu, Hd, Ki, Mo, MW, NP, PC, Pe, SW, Wa.

Range. Warren to Corfe Faunicycles.

Maximum. Mountfield Faunicycle, 23\%.

${ }^{*}$ Cypridea propunctata Sylvester-Bradley, 1949

(Pl. 5, fig. 8)

Material. 3297 specimens from $\mathrm{Br}, \mathrm{CD}, \mathrm{DB}, \mathrm{Fa}, \mathrm{Gu}, \mathrm{He}$, $\mathrm{Ki}, \mathrm{Mo}, \mathrm{NP}, \mathrm{PC}, \mathrm{Pe}$, Wa.

Range. Scallop to Battle Faunicycles (mainly Upper Purbeck).

Maximum. Brede Faunicycle, $28 \%$. This is a typical Upper Purbeck species.

\section{Cypridea pseudomarina Anderson, 1967}

(PI. 10, fig. 7)

Material. Specimens from At, HB, Rd.

Range. Ditchling to Atherfield Faunicycles. A rare form in the Upper Weald Clay. 
${ }^{*}$ Cypridea pumila Anderson, 1967

(PI. 10, fig. 4)

Material. 3416 specimens from $\mathrm{CH}, \mathrm{Cu}, \mathrm{DS}, \mathrm{Ha}, \mathrm{He}, \mathrm{Ki}$, Po, Py, Re, So, Wa, Wm.

Range. Hailsham to Newdigate Faunicycles (Lower Weald Clay).

Maximum. Buxted Faunicycle, 23\%.

This is a characteristic species of the Lower Weald Clay. It is closely associated with $C$. marina .

*Cypridea recta Wolburg, 1959

Material. 2357 specimens from CD, Co, FL, Gl, Ki, LM, St, Wa, We, WP.

Range. Hastings to Cuckfield Faunicycles (Ashdown Sand, Wadhurst Clay and Tunbridge Wells Sand).

Maximum. Crowhurst Faunicycle, 56\%.

Subspecies edithae Anderson, 1967

Grinstead Clay only

(Pl. 8, fig. 5)

Subspecies inflata Wolburg, 1959

Grinstead Clay only

(Pl. 8, fig. 7)

Subspecies recta Wolburg, 1959

Hastings to Grinstead Faunicycles

(Pl. 8, fig. 4)

Subspecies tillsdenensis Anderson, 1967

Lindfield to Cuckfield Faunicycles,

characteristic of the Tunbridge Wells Sand

(Pl. 8, fig. 1)

${ }^{*}$ Cypridea rotundata Anderson, 1967

(Pl. 10, fig. 9)

Material. 825 specimens from At, BM, CF, Do, GP, $\mathrm{HB}, \mathrm{Re}, \mathrm{SB}, \mathrm{Wa}$.

Range. Pluckley to Earlswood Faunicycles (Upper Weald Clay).

Maxima. Gillmans and Ditchling Faunicycles, 97\%. This is a characteristic form in the Petworth Marble.

\section{${ }^{*}$ Cypridea sagena Anderson, 1971}

(Pl. 3, fig. 13)

Material. 1430 specimens from $\mathrm{Br}, \mathrm{CD}, \mathrm{Fa}, \mathrm{GD}, \mathrm{Hd}, \mathrm{Ki}$, Mo, MW, NP, NW, PC, Wa.

Range. Burwash to Nothe Faunicycles (Middle Purbeck). Maximum. Mountfield Faunicycle, 44\%.

${ }^{*}$ Cypridea setina (Anderson, 1939)

Material. 3438 specimens from $\mathrm{Br}, \mathrm{CD}, \mathrm{DB}, \mathrm{Fa}, \mathrm{Gu}, \mathrm{He}$, $\mathrm{Ki}, \mathrm{Mo}, \mathrm{NP}, \mathrm{OM}, \mathrm{Pe}, \mathrm{Po}, \mathrm{Pt}, \mathrm{Wa}$.

Range. Studland to Rye Faunicycles (mainly Upper Purbeck).

Maximum. Brede Faunicycle, 25\%.

$C$. setina rectidorsata and $C$. setina setina are by far the commonest subspecies. Both are characteristic of and abundant in the Upper Purbeck.

Subspecies acerata Anderson, 1962

Upper Purbeck and Ashdown Sand

(Pl. 5, fig. 12)
Subspecies bellatula Anderson, 1971

Eastbourne Faunicycle

(Pl. 5, fig. 6)

Subspecies camelodes Anderson, 1962

Tyneham Faunicycle

(Pl. 6, fig. 18)

Subspecies deburghi Anderson, 1971

Hastings to Bexhill Faunicycles

(Pl. 6, fig. 7)

Subspecies dotica Anderson, 1962

Tisbury to Durdle Faunicycles

(Pl. 6, fig. 12)

Subspecies erumna Anderson, 1962

Mupes to Battle Faunicycles

(Pl. 6, fig. 6)

Subspecies florida Anderson, 1971

Bexhill to Eastbourne Faunicycles

(Pl. 6, fig. 17)

Subspecies rectidorsata Sylvester-Bradley, 1949

Studland to Battle Faunicycles

(Pl. 6, fig. 14)

Subspecies setina (Anderson, 1939)

Lulworth to Battle Faunicycles

(Pl. 5, fig. 9)

Subspecies pelota nov.

(Pl. 11, fig. 10)

Derivation of name. Spanish, pelota (f), a ball.

Holotype. B.G.S. Mik (M) 2154.

Dimensions. Holotype length $0.89 \mathrm{~mm}$, height $0.61 \mathrm{~mm}$. Locality and horizon. Kingsclere No. 1 Borehole, Hampshire, at $1141 \mathrm{ft}$. $(347.8 \mathrm{~m})$. Rye Faunicycle, Wadhurst Clay, Wealden.

Diagnosis. Carapace rounded, subquadrate in lateral view, outline oval from above. Rostrum very small, alveolus obsolete, cyathus narrow lunate. Length/height ratio 1.46. Left valve the larger.

Description. This subspecies is the last of the $C$. setina stock. In outline it is nearest to the subspecies rectidorsata, but is relatively shorter and higher and the beak and notch are barely visible.

Distribution. Cypridea setina pelota has been recognised with certainty only from the Kingsclere Borehole not far above the base of the Wadhurst Clay, but a few ostracods from this horizon in the Chilcomb Down Borehole may also be of the subspecies.

Cypridea simplissima, new name for $C$. simplex Anderson, 1971, preoccupied by Galeeva, 1955

(Pl. 11, fig. 5)

Material. 2240 specimens from $\mathrm{As}, \mathrm{Bg}, \mathrm{Br}, \mathrm{BW}, \mathrm{CD}$, $\mathrm{DB}, \mathrm{Fa}, \mathrm{GD}, \mathrm{Gu}, \mathrm{Hd}, \mathrm{He}, \mathrm{Ki}, \mathrm{Mo}, \mathrm{MW}, \mathrm{NP}, \mathrm{NW}, \mathrm{Pe}$, Wa.

Range. Upper Soft Cockle to Hythe Faunicycles.

Maxima. Scallop Faunicycle, 10\%; Durdle Faunicycle, $10 \%$. This is a small, simple carapace not easily distinguishable from the juveniles of some other species. 
Cypridea spinigera (J. de C. Sowerby, 1836)

(Pl. 10, fig. 13)

Material. 176 specimens from At, B T, CB, Ch, Ea, Ki, $\mathrm{Rd}, \mathrm{Re}, \mathrm{SB}, \mathrm{Wa}$.

Range. Ditchling to Earlswood Faunicycles (Upper Weald Clay).

Maxima. Sandown and Cuckmere Faunicycles. A rare species.

*Cypridea swanagensis Anderson, 1971

Material. 835 specimens from $\mathrm{Br}, \mathrm{Cd}, \mathrm{Fa}, \mathrm{GD}, \mathrm{He}, \mathrm{Hd}$, Mo, MW, NP, NW, PC.

Range. Netherfield to Peveril Faunicycles (Middle Purbeck).

Maxima. Netherfield and Durlston Faunicycles, 97\%.

Subspecies ornata Anderson, 1971

Durlston Faunicycle only

(Pl. 4, fig. 1)

Subspecies swanagensis Anderson, 1971

Netherfield to Peveril Faunicycles

(Pl. 4, fig. 12)

Cypridea tenuis Anderson, 1967

(Pl. 10, fig. 11)

Material. 100 specimens from At, CB, Hy, Rd, Re, SB, SC, Wa.

Range. Gillmans to Earlswood Faunicycles (Upper Weald Clay).

Maximum. Woodhatch Faunicycle, 34\%. This is a rare species, probably the last of the $C$. setina-laevigatadolabrata group.

${ }^{*}$ Cypridea tuberculata (J. de C. Sowerby, 1836)

Material. 9430 specimens from $\mathrm{Br}, \mathrm{CD}, \mathrm{CH}, \mathrm{Co}, \mathrm{Cu}$, $\mathrm{DB}, \mathrm{Fa}, \mathrm{Gl}, \mathrm{Gu}, \mathrm{Ha}, \mathrm{Hd}, \mathrm{Ki}, \mathrm{LM}, \mathrm{MB}, \mathrm{Po}, \mathrm{Re}$, So, Wa, Wd, We, Wm, WP.

Range. Worth to Pluckley Faunicycles (Purbeck and Wealden).

Maximum. Lydd Faunicycle.

This is a typical Wealden species, especially characteristic of the Wadhurst Clay and the Henfield phase of the Weald Clay.

Subspecies adjuncta Jones, 1885

Upper Purbeck and Ashdown Sand

(Pl. 5, fig. 4)

Subspecies indigens Anderson, 1939

Lower Weald Clay

(Pl. 11, fig. 11)

Subspecies langtonensis Anderson, 1971

Worth, Langton and Scallop Faunicycles (Middle

Purbeck). Maximum in the Worth Faunicycle

$$
\text { (Pl. 5, fig. 5) }
$$

Subspecies tuberculata (J. de C. Sowerby, 1836)

Lower Wadhurst Clay.

Maxima in the Lydd and Horsted Faunicycles

(Pl. 5, fig. 2)
Subspecies dorsiclavata nov.

(P1. 11, fig. 18)

Derivation of name. Latin, clava, -ae, a knotty branch. Holotype. B.G.S. Mik (M) 4488.

Dimensions. Holotype length $0.915 \mathrm{~mm}$, height $0.655 \mathrm{~mm}$. Locality and horizon. Warninglid Borehole, Sussex, at 47-48ft (14.32-14.63 m). Hackhurst Faunicycle, Horsham phase, $C$. dorsispinata Zone. Weald Clay.

Diagnosis. Carapace oblong-ovate in lateral view. Rostrum medium sized, alveolus medium sized, cyathus cupate?. Shell surface covered with medium sized punctations and ornamented with sharp tubercles or blunt spines over the whole surface. The 3 lumbar tubercles are conspicuous and usually larger than the rest. The left valve is the larger.

Description. The ornament pattern in this subspecies is similar to that generally found in C. tuberculata but the large lumbar tubercles are distinctive. No individuals have yet been found with a well preserved cyathus.

Distribution. This form is characteristic of the lower part of the Weald Clay (Horsham phase). It has been found in the Warlingham Borehole (Hackhurst Faunicycle), the Warninglid Borehole (Redhill and Hackhurst Faunicycles). In the Henfield phase above, the 3 lumbar tubercles are less conspicuous and both at the Southwater Brick Pit and at Warninglid a variety occurs in which the ocular tubercle may be conspicuously large.

*Cypridea tumescens (Anderson, 1939)

Material. 2496 specimens from As, Ay, Bg, Br, CD, DB, $\mathrm{Fa}, \mathrm{FW}, \mathrm{GD}, \mathrm{Gu}, \mathrm{Hd}, \mathrm{He}, \mathrm{Ki}, \mathrm{Mo}, \mathrm{Nd}, \mathrm{NP}, \mathrm{Py}, \mathrm{Ri}, \mathrm{Sw}$, Wa.

Range. Quainton to Worth Faunicycles (Lower and Middle Purbeck).

Maximum. Goldspur Faunicycle, 18\%.

This is a characteristic species in the Lower and lower Middle Purbeck.

Subspecies acrobeles Anderson, 1971

Quainton to Robertsbridge Faunicycles. Maximum in Hard Cockle Faunicycle

(Pl. 1, fig. 14)

Subspecies praecursor Oertli, 1963

Burwash to Ashdown Faunicycles. Maximum in the Goldspur Faunicycle

(Pl. 1, fig. 16)

Subspecies tumescens (Anderson, 1939)

Swanage to Croydon Faunicycles. Maximum in the Durlston Faunicycle

(Pl. 1, fig. 13)

${ }^{*}$ Cypridea valdensis (J. de C. Sowerby, 1836)

Material. 3216 specimens from $\mathrm{BP}, \mathrm{CH}, \mathrm{Cu}, \mathrm{Ha}, \mathrm{Hy}, \mathrm{Ki}$, $\mathrm{Re}$, So, Wa, Wm.

Range. St. Leonards to Cuckmere Faunicycles.

Maxima. Edenbridge Faunicycle, 17\%; Gillmans Faunicycle, $17 \%$. 
Subspecies clareae Anderson, 1967

Distribution as for the species but rare.

(Pl. 8, fig. 15)

Subspecies claudii Anderson, 1967

Distribution as for the species but rare.

(Pl. 8, fig. 12)

Subspecies valdensis (J. de C. Sowerby, 1836)

The usual form of the species; common in the Weald Clay of all areas.

(Pl. 8, fig. 18)

Cypridea varians Anderson, 1971

(Pl. 11, fig. 12)

Material. 254 specimens from Br, CD, DB, Fa, GD, Gu, Ki, Mo, MW, NP, NW, Wa, WB.

Range. Mountfield to Hastings Faunicycles.

Maximum. Battle Faunicycle.

\section{Cypridea vectae Anderson, 1967}

(Pl. 11, fig. 1)

Remarks. A rare species known only from the Woodhatch Faunicycle of the Weald Clay at CB, Rd, Re, SC.

\section{Cypridea ventrosa Jones, 1885}

$$
\text { (P1. 7, fig. 18) }
$$

Remarks. A rare species in the Upper Purbeck of Dorset, Mupes to Hastings Faunicycles at DB and Ki. Not recorded from the Weald.

\section{Cypridea vericae Anderson, 1967}

(Pl. 9, fig. 6)

Material. 105 specimens from Co, FL, Gl, St, We, WP. Range. Lindfield to Fletching Faunicycles (Wadhurst Clay).

Maximum. Hawkhurst Faunicycle, 59\%, a rare species.

\section{Cypridea verrucosa Jones, 1878}

(Pl. 8, fig. 17)

Material. 292 specimens from CD, FL, Ki, Sh, Wa.

Range. St. Leonards to Grinstead Faunicycles.

Maximum. Fletching Faunicycle.

\section{*Cypridea vidrana Wolburg, 1959}

(Pl. 5, fig. 17)

Material. 970 specimens from As, Bg, Br, B W, CD, DB, $\mathrm{Fa}, \mathrm{GS}, \mathrm{Gu}, \mathrm{Hd}, \mathrm{He}, \mathrm{Mo}, \mathrm{MW}, \mathrm{Py}$, Wa.

Range. Langton to Greenwood Faunicycles (upper Middle Purbeck).

Maximum. Bacon Faunicycle, 53\%.

This species succeeds $C$. amisia as the dominant form in the upper part of the Middle Purbeck.

\section{Cypridea warlinghamensis Anderson, 1967}

(P1. 11, fig. 2)

Material. 50 specimens from Rd, Re, SB, SC, Wa.

Range. Woodhatch to Earlswood Faunicycles (Upper Weald Clay).

Maximum. Cuckmere Faunicycle. A rare species.
${ }^{*}$ Cypridea wicheri Wolburg, 1959

Material. 1644 specimens from $\mathrm{CD}, \mathrm{DB}, \mathrm{Fa}, \mathrm{Gu}, \mathrm{He}, \mathrm{Ki}$, Mo, Pe, Po, Wa.

Range. Bacon to Bexhill Faunicycles (Middle PurbeckAshdown Sand).

Maximum. Durdle Faunicycle, $43 \%$.

Subspecies croesi Anderson, 1971

Lulworth to Bexhill Faunicycles, maximum in Bexhill Faunicycle

(Pl. 6, fig. 13)

Subspecies isabellae Anderson, 1971

Lulworth to Bexhill Faunicycle

(Pl. 6, fig. 1)

Subspecies torosa Anderson, 1971

Lulworth to Bexhill Faunicycles (P1. 6, fig. 2)

Subspecies veronae Anderson, 1971

Mupes to Bexhill Faunicycles, maximum in Brede Faunicycle

(P1. 6, fig. 4)

Subspecies wicheri Wolburg, 1959

Bexhill Faunicycle only

(Pl. 6, fig. 10)

Subspecies wicki Wolburg, 1959

Bacon to Tyneham Faunicycles, maximum in Lulworth Faunicycle; Upper Purbeck (P1. 6, fig. 16)

*Cypridea wolburgi Anderson, 1971

(An inverse species)

(Pl. 11, fig. 13)

Material. 363 specimens from $\mathrm{CD}, \mathrm{He}, \mathrm{Wa}$.

Range. Greenwood to Mupes Faunicycles.

Maximum. Lulworth Faunicycle.

\section{OTHER GENERA}

Genus Bisulcocypris Pinto \& Sanguinetti, 1962 Bisulcocypris dilatata Anderson, 1971

(Pl. 3, fig. 10)

Material. 158 specimens from Ay, DB, FW, He, Mo, MW, NW, PC.

Range. Swindon to Corfe Faunicycles (Lower and Middle Purbeck).

Maximum. Swanage Faunicycle, 37\%.

Bisculcocypris striata (Martin, 1940)

Material. 1507 specimens from As, CD, DB, GD, Gu, $\mathrm{He}, \mathrm{Ki}, \mathrm{Mo}, \mathrm{MW}, \mathrm{Np}, \mathrm{NW}, \mathrm{OM}, \mathrm{Pe}$, Wa.

Range. Upwey to Rye Faunicycles (Purbeck to basal Wadhurst Clay).

Maximum. Netherfield Faunicycle, 14\%.

Subspecies monotuberculata Anderson, 1971 Studland to Mupes Faunicycles

(P1. 3, fig. 2)

Subspecies striata (Martin, 1940)

Upway to Rye Faunicycles

(Pl. 3, fig. 1) 
Genus Cytheridea Bosquet, 1852

Subgenus Haplocytheridea Stephenson, 1936 Cytheridea (Haplocytheridea) delicatula Martin, 1961 (Pl. 8, fig. 9)

Material. Specimens from $\mathrm{CH}, \mathrm{Re}, \mathrm{Wa}$.

Range. Rye to Hawkhurst Faunicycles (Wadhurst Clay); Plumpton to Bonnington Faunicycles (Weald Clay).

Maximum. Capel Faunicycle, 60\%.

Genus Damonella Anderson, 1966

Damonella buchaniana Anderson, 1966

(Pl. 2, fig. 13)

Material. 504 specimens from BT, DB, Mo, Po.

Range. Upwey to Newdigate Faunicycles (mainly Purbeck, rare in the Wealden).

Maximum. Durlston Faunicycle, 27\%.

\section{Damonella denticulata Anderson, 1966}

(Pl. 11, fig. 16)

Remarks. A rare form in the upper part of Weald Clay at GP, Wa.

\section{Damonella ellipsoidea (Wolburg, 1962)}

(Pl. 2, fig. 4)

Material. 676 specimens from DB, He, Ki, Mo, VW.

Range. Warren to Sandhurst Faunicycles (mainly Lower and Middle Purbeck).

Maximum. Corfe Faunicycle, 20\%.

Damonella punctatula Anderson, 1966

(PI. 11, fig. 17)

Remarks. A rare species known only from the Hawkhurst Faunicycle of the Wadhurst Clay at WP.

Damonella pygmaea (Anderson, 1941)

(Pl. 2, fig. 7)

Material. 1333 specimens from DB, Ki, Mo, SW.

Range. Warren to Gillmans Faunicycles (Purbeck and Wealden).

Maximum. Hailsham Faunicycle, 17\%.

Genus Darwinula Brady \& Robertson, 1885

Darwinula jonesi Anderson, 1971

(Pl. 11, fig. 7)

Material. 104 specimens from At, Bg, Ha, Mo, Wa, Wy.

Range. Durlston to Grinstead Faunicycles (mainly Wadhurst Clay).

Maximum. Rye Faunicycle, $63 \%$.

\section{Darwinula leguminella (Forbes, 1855)}

(Pl. 11, fig. 8)

Material. 9112 specimens from almost all localities.

Range. Warren to Cuckmere Faunicycles (Purbeck and Wealden).

Maximum. Hawkhurst Faunicycle, 10\%.
Darwinula oblonga (Roemer, 1839)

(Pl. 11, fig. 9)

Material. 4819 specimens. A ubiquitous species in the Purbeck and Wealden. Usually occurs with $D$. leguminella.

Range. Upwey to Cuckmere Faunicycles.

Maximum. Mountfield Faunicycle, 10\%.

Genus Eocytheridea Bate, 1963

Eocytheridea eusarca (Anderson, 1941)

(Pl. 1, fig. 15)

Material. 304 specimens from Ay, Sw.

Range. Quainton to Stair Faunicycles (Lower Purbeck).

Maximum. Warren Faunicycle, $88 \%$.

Eocytheridea oleroni (Donze, 1960)

(Pl. 12, fig. 20)

Material. 38 specimens from Ay, Sw.

Range. Quainton to Langton Faunicycles (Purbeck).

Maximum. Langton Faunicycle, $79 \%$.

Genus Eoparacypris Anderson, 1971

Eoparacypris abbreviata Anderson, 1971

(Pl. 11, fig. 6)

Material. 17 specimens from CD.

Range. Worth to Langton Faunicycles (Purbeck).

Maximum. Langton Faunicycle, 89\%.

Eoparacypris attenuata Anderson, 1971

(Pl. 12, fig. 1)

Material. 32 specimens from $\mathrm{CD}, \mathrm{He}, \mathrm{MW}$, Wa.

Range. Goldspur to Poxwell Faunicycles (Purbeck).

Maximum. Bacon Faunicycle, 63\%.

Eoparacypris edmundsi sp. nov.

(Pl. 12, fig. 4)

Derivation of name. For F. H. Edmunds for his contributions to the geology of the Weald.

Holotype. B.G.S. Mik (M) 3279.

Dimensions. Holotype length $0.370 \mathrm{~mm}$, height $0.185 \mathrm{~mm}$. Locality and horizon. Warlingham Borehole, Surrey, depth $1070 \mathrm{ft}$. $10 \mathrm{in}$. (326.41 m), Weald Clay, Sandown Faunicycle.

Diagnosis. Carapace small. In lateral view elongatetriangular. Anterior margin evenly rounded and with a broad flange. Dorsal margin almost straight, backward sloping. Posterior acutely triangular. Ventral margin slightly sinuous. Shell surface smooth, glossy.

Description. This small species is found rarely in the more saline phases of the upper part of the Weald Clay. Though similar to $E$. edwardi in size, it is easily distinguished by having a more acute posterior to the shell. $E$. parallela, though similar in shape to $E$. edmundsi, is longer, lower, and more acute posteriorly.

Distribution. A rare species from the Sandown Faunicycle (Upper Weald Clay) of the Warlingham Borehole (Wa). 
Eoparacypris edwardi Anderson, 1971

(Pl. 12, fig. 11)

Material. A rare species from Wa, WP.

Range. Wadhurst Clay to Lower Weald Clay.

Maximum. Fairlight and Lindfield Faunicycles.

Eoparacypris macroselina Anderson, 1971

(Pl. 3, fig. 6)

Material. 60 specimens from CD, Gu, NP, Pe, Wa.

Range. Lower Soft Cockle to Tyneham Faunicycles (Purbeck).

Maximum. Goldspur Faunicycle, 32\%.

Eoparacypris parallela (Neale, 1962)

(Pl. 12, fig. 3)

Material. 24 specimens from CD, Gu, MW, NP, Wa.

Range. Scallop to Hythe Faunicycles (Purbeck and Wealden).

Maximum. Tyneham Faunicycle, 33\%.

Eoparacypris surriensis Anderson, 1971

(PI. 12, fig. 2)

Remarks. A rare species ranging from the Mountfield to the Grinstead Faunicycles at CD, Gu, PQ, Wa.

\section{Eoparacypris weedonensis Anderson, 1971}

(Pl. 1, fig. 9)

Material. 739 specimens from As, Bg, CD, DB, Gu, Ki, Mo, NP, Pe, Sw.

Range. Swindon to Durdle Faunicycles (Purbeck).

Maximum. Swanage Faunicycle, 31\%.

Genus Fabanella Martin, 1961

Fabanella ansata (Jones, 1885)

(Pl. 1, fig. 12)

Material. 1654 specimens from Ay, Bg, DB, FW, GD, $\mathrm{He}, \mathrm{Ki}, \mathrm{Mo}, \mathrm{PC}, \mathrm{Pe}, \mathrm{Po}, \mathrm{SO}, \mathrm{Sw}$, Wa.

Range. Quainton to Netherfield Faunicycles (mainly Lower Purbeck).

Maximum. Warren Faunicycle, 62\%.

${ }^{*}$ Fabanella boloniensis (Jones, 1882)

(P1. 1, fig. 6)

Material. 14642 specimens from $\mathrm{Ay}, \mathrm{Bg}, \mathrm{Br}, \mathrm{Bu}, \mathrm{CD}$, $\mathrm{DB}, \mathrm{Fa}, \mathrm{GD}, \mathrm{Gu}, \mathrm{He}, \mathrm{Ki}, \mathrm{Mo}, \mathrm{NP}, \mathrm{OM}, \mathrm{Py}, \mathrm{Wa}$.

Range. Quainton to Ewhurst Faunicycles (mainly Lower Purbeck but with possible specimens to top of Wealden.

Maximum. Burwash Faunicycle, 12\%. $40 \%$ of the specimens seen were found in the Robertsbridge to Goldspur Faunicycles (high Lower Purbeck to base Middle Purbeck).

Fabanella dimorpha Anderson, 1971

(PI. 12, fig. 12)

Remarks. A rare species known only from the Upper Purbeck at Ki.
Genus Galliaecytheridea Oertli, 1957

${ }^{*}$ Galliaecytheridea postsinuata Wolburg, 1962

(Pl. 4, figs. 3, 9)

Material. 6344 specimens from Ar, As, CD, GD, He, LR, Mo, MW, NW, Po, VW, Wa.

Range. Durlston to Corfe Faunicycles (possibly also in the Swanage Faunicycle).

Maximum. Cinder Beds Faunicycle, 94\%. An important species indicating a higher than normal salinity. Characteristic of the Cinder Beds everywhere.

Genus Klieana Martin, 1940

*Klieana alata Martin, 1940

(P1. 2, figs. 1, 2)

Material. 1864 specimens from As, Ay, Bg, DB, GD, $\mathrm{Gu}, \mathrm{Ki}, \mathrm{Mo}$, NP, Sw, Wa.

Range. Quainton to Langton Faunicycles (mainly Lower Purbeck).

Maximum. Warren Faunicycle, 35\% (66\% of all known specimens are from the Warren and Ridgeway Faunicycles).

*Klieana dictyota Anderson, 1971

(Pl. 3, fig. 11)

Material. 374 specimens from As, GD, Gu, LR, Mo, MW, NP, NW, Pe, Wa.

Range. Swindon to Nothe Faunicycles (Lower Purbeck). Maximum. Cinder Beds Faunicycle, 97\% (a characteristic high salinity species associated with $G$. postsinuata).

\section{Klieana thoracina Anderson, 1971}

(Pl. 12, fig. 14)

Remarks. Specimens from As, DB, GD, Ki, Mo. A rare form in the Mountfield and Worth Faunicycles.

Genus Macrodentina Martin, 1940

*Macrodentina mediostricta (Sylvester-Bradley, 1941) (Pl. 5, fig. 3)

Material. 1800 specimens from $\mathrm{As}, \mathrm{Bg}, \mathrm{CD}, \mathrm{DB}, \mathrm{Gu}$, $\mathrm{He}, \mathrm{Ki}, \mathrm{Mo}, \mathrm{MW}, \mathrm{PC}$, Wa.

Range. Corfe to Mupes Faunicycles (a typical form in the upper Middle Purbeck).

Maximum. Scallop Faunicycle, 42\%.

${ }^{*}$ Macrodentina retirugata (Jones, 1885)

(Pl. 1, fig. 4)

Material. 896 specimens from the basal Purbeck Beds at Swindon and in the Aylesbury area.

Range. Quainton to Warren Faunicycles.

Maximum. Quainton Faunicycle, 98\%.

*Macrodentina rugulata (Jones, 1885)

(Pl. 1, fig. 2)

Material. 1553 specimens from the basal Purbeck Beds at Swindon and in the Aylesbury area.

Range. Quainton to Stair Faunicycles.

Maximum. Quainton Faunicycle, 69\%. 
*Macrodentina transiens (Jones, 1885)

(Pl. 1, fig. 3)

Material. 667 specimens from the basal Purbeck Beds at Swindon and in the Aylesbury area.

Range. Quainton to Warren Faunicycles.

Maximum. Quainton Faunicycle, 89\%.

Genus Mantelliana Anderson, 1966.

Mantelliana cyrton Anderson, 1971.

(Pl. 2, fig. 17; Pl. 3. fig. 16)

Material. 107 specimens from CD, GD, Gu, He, Mo, NP.

Range. Swindon to Langton Faunicycles (mainly Lower Purbeck).

Maximum. Wardour Faunicycle, 36\%.

*Mantelliana mantelli (Jones, 1888)

(Pl. 9, fig. 5)

Material. 511 specimens from At, Bm, BT, TW.

Range. Egerton to Earlswood Faunicycles (Weald Clay).

Maximum. Earlswood Faunicycle, 17\%.

${ }^{*}$ Mantelliana phillipsiana (Jones, 1888)

(Pl. 8, fig. 6)

Material. 414 specimens from $\mathrm{BH}, \mathrm{Gu}, \mathrm{Hs}, \mathrm{Sh}, \mathrm{SL}, \mathrm{TW}$, Wa.

Range. Rye to Hawkhurst Faunicycles (Wadhurst Clay).

Maximum. Wadhurst Faunicycle, 50\%.

${ }^{*}$ Mantelliana purbeckensis (Forbes, 1855) $\dagger$

(Pl. 2, fig. 15)

Material. 2078 specimens from $\mathrm{Ay}, \mathrm{Bg}, \mathrm{Bt}, \mathrm{CD}, \mathrm{Cn}, \mathrm{DB}$, GD, He, Ki, Mo, NP, Pe, PO, Sw, Wa, WN.

Range. Quainton to Netherfield Faunicycles (mainly Lower Purbeck).

Maximum. Wardour Faunicycle, 28\%.

${ }^{*}$ Mantelliana wealdensis (Wolburg, 1962)

(Pl. 2, fig. 10, 18)

Material. 2049 specimens from $\mathrm{Bg}, \mathrm{CD}, \mathrm{Gu}, \mathrm{He}, \mathrm{MW}$, NP, NW, Pe, Wa.

Range. Hard Cockle to St. Leonards Faunicycles (mainly Purbeck).

Maximum. Ashdown Faunicycle, 50\%.

Genus Miocytheridea Anderson, 1967

${ }^{*}$ Miocytheridea henfieldensis (Anderson, 1939).

(P1. 9, fig. 14)

Material. 5605 specimens from He, Py, Wa.

Range. Egerton to Atherfield Faunicycles (Weald Clay). Maximum. Edenbridge Faunicycle, 17\%.

†The lectotype of the species, B.G.S. Mik (M) 2090, was chosen by Anderson (1966a, pp. 437-439) from a fragment of hard Lower Purbeck limestone numbered 4273 (Gibbs Coll. c. 1849). Recent curation by A. A. Morter shows that this piece of limestone, now re-numbered GSM 117568, came from the Lower Purbeck, "Cypris Bed No. 7 in O', the ' $O$ ' referring to the letter system used by Austen (1852) and Forbes (in litt. in B.G.S.), from Bacon Hole, east of Lulworth Cove, Dorset and is not from Durlston Bay near Swanage as cited by Anderson.
Genus Orthonotacythere Alexander, 1933

Remarks. In 1974, Bassiouni erected a new genus Paranotacythere for the Upper Jurassic-Lower Cretaceous species of Orthonotacythere with $O$. diglypta Triebel as type.

Orthonotacythere auricula Martin, 1961

(Pl. 12, fig. 21)

Remarks. A very rare species so far seen only in the Mupes Faunicycle.

Orthonotacythere cineraria Anderson, 1971

$$
\text { (Pl. 4, fig. 6) }
$$

Material. 101 specimens from As, GD, Mo, MW, NW, PC, Wa.

Range. Peveril to Corfe Faunicycles (Middle Purbeck). Maximum. Cinder Beds Faunicycle, $65 \%$.

Orthonotacythere diglypta Triebel, 1941

(Pl. 12, fig. 6)

Remarks. A rare species seen in the Fairlight, Wadhurst, Hawkhurst Faunicycles of the Wadhurst Clay, and the Romney Faunicycle of the Weald Clay at CD.

Orthonotacythere favulata Martin, 1940

(Pl. 3, figs. 5, 7)

Material. 69 specimens from DB, GD, Gu, Mo, NP, Wa. Range. Wardour to Durlston Faunicycles (Lower and Middle Purbeck).

Maximum. Goldspur Faunicycle, 65\%.

Orthonotacythere inversa (Cornuel, 1848)

(Pl. 12, fig. 5)

Remarks. A very rare species in the Upper Weald Clay at Atherfield.

Orthonotacythere nodosaria Anderson, 1971

$$
\text { (Pl. 4, figs. 4, 5) }
$$

Material. 264 specimens from $\mathrm{Bg}, \mathrm{Gu}, \mathrm{Mo}, \mathrm{PC}$, Wa. Range. Cinder Beds to Mupes Faunicycles (Middle Purbeck).

Maximum. Bacon Faunicycle, 30\%.

Orthonotacythere rimosa Martin, 1940

(Pl. 1, fig. 17)

Material. 80 specimens from Ay.

Range. Quainton to Poxwell Faunicycles (Lower Purbeck).

Maximum. Quainton Faunicycle, 95\%.

Genus Palaeocytheridea Mandelstam, 1947.

Palaeocytheridea pellucida (Anderson, 1939)

(PI. 12, fig. 16)

Remarks. A rare form from the Grinstead Faunicycle at $\mathrm{He}, \mathrm{PQ}$. Of the two syntypes of Candona pellucida Anderson, 1939; GSM 60673 and GSM 60674, the former is figured on Pl. 12, fig. 16 and is selected as lectotype; it now has the number Mik (M) 526 in the B.G.S. Collection. GSM 60674 (now Mik (M) 527) is in poor condition. 
Genus Paraschuleridea Swartz \& Swain, 1946

Paraschuleridea buglensis Barker, 1966

(Pl. 1, fig. 5)

Material. 308 specimens from localities in the Aylesbury area.

Range. Quainton to Robertsbridge Faunicycles (Lower Purbeck).

Maximum. Warren Faunicycle, 70\%.

Genus Procytheropteron Ljubimova, 1955

Procytheropteron barkeri Anderson, 1971

(Pl. 2, fig. 3)

Material. 366 specimens from Ay.

Range. Quainton to Wardour Faunicycles (Lower Purbeck).

Maximum. Quainton Faunicycle, 32\%.

\section{Procytheropteron brodiei (Jones, 1894)}

(Pl. 5, fig. 1)

Material. 17 specimens from As, GD, MW, NW, Wa, VW.

Range. Peveril to Nothe Faunicycles (Middle Purbeck). Maximum. Cinder Beds Faunicycle.

Genus Protocythere Triebel, 1938

Protocythere serpentina (Anderson, 1941)

(Pl. 1, fig. 7)

Material. 555 specimens from Ay and Sw.

Range. Quainton to Stair Faunicycles (Lower Purbeck).

Maximum. Quainton Faunicycle, 79\%.

Genus Pseudoparacypridopsis Anderson, 1971

*Pseudoparacypridopsis mountfieldensis Anderson, 1971 (Pl. 3, fig. 3)

Material. 987 specimens from $\mathrm{Bg}, \mathrm{CD}, \mathrm{GD}, \mathrm{Gu}, \mathrm{He}$, Mo, MW, NP, Wa.

Range. Lower Soft Cockle to Battle Faunicycles (Purbeck).

Maximum. Mountfield Faunicycle, 44\%.

Genus Rhinocypris Anderson, 1941

*Rhinocypris jurassica (Martin, 1940)

(Pl. 2, fig. 5)

Material. 3449 specimens from Bg, B W, CD, DB, GD, $\mathrm{Gu}, \mathrm{He}, \mathrm{Ki}, \mathrm{Mo}, \mathrm{MW}, \mathrm{NP}, \mathrm{NW}, \mathrm{OM}, \mathrm{Pe}, \mathrm{Po}, \mathrm{Sw}, \mathrm{Wa}$.

Range. Warren to Gillmans Faunicycles (Purbeck and Wealden).

Maximum. St. Leonards Faunicycle, 17\%.

Genus Scabriculocypris Anderson, 1941

Scabriculocypris acanthoides Anderson, 1941

(PI. 12, fig. 17)

Remarks. A rare species found mainly in the Lower Purbeck at Swindon, but a few specimens were also obtained from the Mountfield and Tisbury Faunicycles in the Ashdown Borehole.
Scabriculocypris cerastes Anderson, 1941

(Pl. 12, fig. 18)

Remarks. A rare species in the Warren and Ringstead Faunicycles at Swindon. Appears occasionally in the Middle and Upper Purbeck in the Mountfield and Warlingham boreholes.

Scabriculocypris durlstonensis Anderson, 1971

(P1. 4, figs. 15, 17)

Material. 145 specimens from CD, DB.

Range. Mountfield to Bacon Faunicycles (Purbeck).

Maximum. Corfe Faunicycle, $62 \%$.

*Scabriculocypris trapezoides Anderson, 1941

(P1. 2, fig. 14)

Material. 1704 specimens from As, Ay, Bg, CD, GD, $\mathrm{Gu}, \mathrm{He}, \mathrm{Ki}, \mathrm{Mo}$, NP, PC, Pe, Po, Sw, Wa.

Range. Quainton to Fletching Faunicycles (mainly Lower and Middle Purbeck).

Maximum. Goldspur Faunicycle, 27\%.

Genus Stenestroemia Christensen, 1968

Stenestroemia cressida Anderson, 1971

(Pl. 12, fig. 13)

Remarks. A rare form seen only in the Grinstead Faunicycle of the Kingsclere Borehole.

Stenestroenia decipiens (Anderson, 1941)

(Pl. 12, fig. 8)

Remarks. A rare species ranging from the Warren to the Hard Cockle Faunicycle (Lower Purbeck) at Ay, DR, Sw.

*Stenestroemia fragilis (Martin, 1940)

$$
\text { (Pl. 2, fig. 6) }
$$

Material. 361 specimens from As, $\mathrm{Ay}, \mathrm{Bg}, \mathrm{BW}, \mathrm{DB}$, GD, Gu, Mo, MW, NP, NW, Pe, Wa.

Range. Ridgeway to Crowhurst Faunicycles (Purbeck and Wealden).

Maximum. Studland Faunicycle, 16\%.

Genus Sternbergella Wolburg, 1962

Sterbergella cornigera (Jones, 1888)

(P1. 11, fig. 3)

Remarks. A rare species found in the Weald Shales of Atherfield Point in the Isle of Wight (At).

Genus Stillina Laurencich, 1957

Stillina arkelli Anderson, 1971

(Pl. 12, fig. 15)

Remarks. A rare species, 31 specimens found in the Cinder Beds Faunicycle at MW and Wa.

Genus Theriosynoecum Branson, 1936

*Theriosynoecum alleni (Pinto \& Sanguinetti, 1962)

(Pl. 7, fig. 15)

Material. 4365 specimens. A species common in the Wadhurst Clay.

Range. Hastings to Philpotts Faunicycles.

Maximum. Kingsclere Faunicycle, 26\%. 
${ }^{*}$ Theriosynoecum fittoni (Mantell, 1844)

(Pl. 9, figs. 12, 13)

Material. 4903 specimens. A species common in the Upper Weald Clay.

Range. Sevenoaks to Earlswood Faunicycles.

Maximum. Woodhatch Faunicycle, 17\%.

${ }^{*}$ Theriosynoecum forbesi (Jones, 1885)

Material. 604 specimens from Ay, Bt, CD, DB, FW, GD, Gu, He, MB, Mo, NP, NW, OM, PC, Po, Ri, Up, Wa.

Range. Warren to Eastbourne Faunicycles (mainly Purbeck).

Maximum. Netherfield Faunicycle, 31\%.

Subspecies forbesi (Jones, 1885)

(Pl. 2, fig. 9)

Subspecies verrucosa (Jones, 1885)

(PI. 2, fig. 8)

Genus Timiriasevia Mandelstam, 1947

Timiriasevia punctata Clements, 1973

(Pl. 3, fig. 4)

Material. 106 specimens from $\mathrm{Bg}, \mathrm{DB}, \mathrm{Gu}, \mathrm{Ki}, \mathrm{Mo}$, MW, Wa, WB.

Range. Wardour to Hawkhurst Faunicycles (Purbeck and Wealden).

Maximum. Eastbourne Faunicycle, 38\%.

Genus Wolburgia Anderson, 1966

Wolburgia atherfieldensis Anderson, 1966

(Pl. 12, fig. 10)

Remarks. A rare species found in the Upper Weald Clay at Atherfield and in the Chilcomb Down Borehole.

\section{Wolburgia polyphema Anderson, 1966}

(Pl. 12, fig. 7)

Remarks. A rare species from the Lower Purbeck (Upway to Hard Cockle Faunicycle) in the Mountfield Boreholes.

\section{Wolburgia tavola Anderson, 1966}

$$
\text { (Pl. 12, fig. 9) }
$$

Remarks. A very rare species known only from the Upper Purbeck (Lulworth Faunicycle) in the Chilcomb Down Borehole.

\section{Wolburgia visceralis (Anderson, 1941)}

$$
\text { (Pl. 1, fig. 1) }
$$

Remarks. Only 76 specimens known, mainly from the Upper Portland Beds at Bugle Pit, Aylesbury. A few individuals continued into the basal Purbeck Beds (Quainton and Warren Faunicycles) at Bugle Pit and Warren Park, both near Aylesbury.

\section{LOCALITIES QUOTED IN THE TEXT}

Important sites are marked with an asterisk $\left(^{*}\right)$ and $1^{\prime \prime}$ Sheet numbers are of the Geological Survey maps. Detailed localities and horizons are not available for some of these records.

*Ar Arreton No. 1 Borehole, Isle of Wight, SZ/5307 8564, 1" 331, Wealden-Purbeck, 210-2563ft, (64-781 m).

*As Ashdown No. 1 Borehole, 1954, Sussex, TQ/ 5006 3035, 1" 303, Wealden (Ashdown Beds)Purbeck to $1099 \mathrm{ft},(335 \mathrm{~m})$.

*At Atherfield Point, Isle of Wight, SZ/450 790, 1" 344, Weald shales.

${ }^{*}$ Ay Aylesbury area, Buckinghamshire (see also Bugle Pit), 1" 237, Portland-Purbeck junction.

BG Buck's Green, Sussex, TQ/076 328, TQ/082 327,1 " 302, Lower Weald Clay.

${ }^{*} \mathrm{Bg}$ Brightling No. 27 Borehole, 1961, Sussex, TQ/ 687 198, 1" 320, Partly cored, Purbeck 484$966 \mathrm{ft} 8$ in, (147.5-294.6 m).

BH Black Horse Quarry, near Battle, TQ/769 142, 1" 320, Wadhurst Clay.

Bl Blackbush Wood, Kent, TQ/738 357, 1" 304, Wadhurst Clay.

BM Barham Mill, Kent, TQ/875 466, 1" 288, Upper Weald Clay.

Bo Bogden, Kent, TQ/77 46, 1" 288, Weald Clay.

BP Bookhurst Pottery Brick Pit, near Cranleigh, Surrey, TQ/076 394, 1" 301, Weald Clay.

${ }^{*} \mathrm{Br} \quad$ Broadoak Borehole, Sussex, 1974, TQ/61950 22142, 1" 303, Middle and Lower Purbeck, $2.50-133.65 \mathrm{~m}$.

BT Brown's Pit, near Earlswood, Surrey, TQ/2640 4905, 1" 286, Weald Clay.

Bu Bugle Pit, Hartwell, near Aylesbury, Buckinghamshire, SP/793 121, 1" 237, Portland-Purbeck junction.

BW Binglett's Wood, Sussex, TQ/6227 2145, 1" 319 , Purbeck.

CB Cuckmere Brick Pits, Berwick, Sussex, TQ/5265 0765 \& TQ/5255 0700, 1" 319, Upper Weald Clay.

CC Compton Chine, Isle of Wight, SZ/366 852, 1" 330 , Weald Shales.

*CD Chilcomb Down (Winchester) Borehole, Hampshire, 1960, Purbeck and Wealden 0-2015ft, (to $614 \mathrm{~m}$ ).

CF Coldharbour Farm, near Maidstone, Kent, TQ/ 884 461, 1" 288, Weald Clay.

CH Clock House Brick Pit, Capel, Surrey, TQ/174 384, 1" 302, Weald Clay.

CL Copyhold Lane, Sussex, 1" 302, Grinstead Clay.

CN Chaldon Borehole, Chaldon Down, Dorset, 1" 342, Lower Purbeck. 
${ }^{*}$ Co Cooden Borehole, Sussex, 1969, TQ/5705 1064, 1 " 320, Weald Clay 0-44ft (to $13.4 \mathrm{~m}$ ), Tunbridge Wells Sand 44-395ft (13.4 to $120.4 \mathrm{~m})$, Wadhurst Clay $395-476 \mathrm{ft}$, (120.4 to $145 \mathrm{~m})$.

${ }^{*} \mathrm{Cu} \quad$ Cuckfield Boreholes, Sussex, TQ/2962 2729 \& 2961 2731, 1" 302. No. 1 Weald Clay-Ashdown Beds 0-1067 ft, (to $325.2 \mathrm{~m}$ ). No. 2 Lower Weald Clay.

*DB Durlston Bay, Dorset, SZ/034 777, 1" 343, Purbeck.

DM Darwell Mill, Sussex, TQ/6958 2005, 1" 320, Upper Purbeck.

Do Dorking Railway Cutting, Surrey, TQ/189 472, $1 "$ 286, Weald Clay.

DR Darwell Stream, Brightling, Sussex, TQ/6992 2050, 1" 320, Lower Purbeck.

DS Dorking and Sussex Brick Pit, Crowhurst, Sussex, TQ/393 463, 1" 287, Lower Weald Clay.

Ea Earlswood Common (= Brown's Pit), Surrey, TQ/2640 4905, 1" 286, Upper Weald Clay.

EF Egerton Forstal, Kent, TQ/878 465, 1" 288, Upper Weald Clay.

EG East Grinstead (Ashurstwood) Borehole, 1" 303, Wadhurst Clay.

*Fa Fairlight Borehole, Sussex, TQ/8592 1173, 1" 320, Purbeck, Ashdown Beds, Wadhurst Clay.

FF Fisher's Farm, Staplehurst, Kent, TQ/787 443, 1" 288, Lower Weald Clay.

*FL Freshfield Lane Brickworks, TQ/3806 2650, 1" 302, Wadhurst Clay.

FW Friar Waddon, Upwey, Dorset, 1" 327, Purbeck.

*GD Goldspur Drift, Mountfield, Sussex, TQ/7280 1895, 1" 320, Purbeck, below Cinder Beds, $0-255 \mathrm{ft}$, (to $77.7 \mathrm{~m}$ ).

Ge Groombridge, Kent, TQ/530 370, 1" 303, Wealden.

*Gl Glynleigh Borehole, Sussex, TQ/6080 0635, 1" 319, Wadhurst Clay.

GP Gillman's Brick Pit, Billingshurst, Sussex, TQ/ 0855 2471, 1" 301, Weald Clay.

GS Greenwood Stream, Sussex, TQ/637 215, 1" 319, Purbeck.

${ }^{*}$ Gu Guestling Boreholes 1 \& 3, Sussex, TQ/8346 $1390,1^{\prime \prime} 320$, Purbeck c. $364 \mathrm{ft}$. (110.94 m) thick.

${ }^{*} \mathrm{Ha}$ Hailsham Borehole, Sussex, 1972, TQ/5746 1083, 1" 319, Lower Weald Clay.

HB Henfield Brickworks, Sussex, TQ/2175 1425, 1" 318 , Weald Clay.

HC Highbridge Railway Cutting, 1" 302, Grinstead Clay.

${ }^{*}$ Hd Heathfield No. 7 Borehole, Sussex, TQ/5801 2112, 1" 319, Lower and Middle Purbeck.
${ }^{*} \mathrm{He}$ Henfield No. 1 Borehole, Sussex, TQ/1799 1957, 1" 318, Wealden and Purbeck.

Hi High Halden, Kent, TQ/861 368, 1" 304, Lower Weald Clay.

Hn Hampden Park Borehole, Sussex, TQ/6119 0204, 1" 334, Upper Weald Clay.

HO Hounstout Cliff, Dorset, SY/952 772, 1" 343, Portland Beds.

HP High Brooms Brick and Tiles Works, Southborough, Kent, TQ/594 418 1" 287, Wadhurst Clay.

Hs Holmans, near Wittersham, Kent, TQ/924 270, 1" 304, Wadhurst Clay.

HW Holman's Wood (= Birchen Wood), Brightling, Sussex, TQ/6930 2036 to $69372050,1^{\prime \prime} 320$, Purbeck.

Hy Hythe, Kent, TQ/186 353, 1" 305, Upper Weald Clay.

JL Jeremy's Lane, TQ/262 247, 1" 302, Wealden, Grinstead Clay.

${ }^{*} \mathrm{Ki} \quad$ Kingsclere No. 1 Borehole, Hampshire, 1937, SU/4990 5816, 1" 283, Tunbridge Wells Sand to Lower Purbeck.

${ }^{*}$ LM Little Maxfield Borehole, Sussex, TQ/8414 $1532,1^{\prime \prime} 320$, Wadhurst Clay.

LR River Line, Sussex, TQ/7159 1908, 1" 320, Purbeck.

MA Mountfield Adit, Sussex, TQ/719 193, 1" 320, Purbeck.

MB Mupes Bay, Dorset, SY/843 797, 1" 342, Purbeck.

${ }^{*}$ Mo Mountfield No. 3, TQ/7240 1875 and No. 4 boreholes TQ/7285 1905, 1" 320, Purbeck.

*MW Milkhurst Wood, Sussex, TQ/6222 2242, 1" 303 , Purbeck.

Nd Netherfield (Sub-Wealden) Borehole, 1874, Sussex, TQ/7194 1930, 1" 320, Mostly Lower Purbeck.

Ne Netherfield Court, Sussex, TQ/7177 1918, 1" 320, ?Middle Purbeck.

*NP Netherfield Place No. 3, TQ/730 178 and No. 5, TQ/720 184 boreholes, Sussex, Purbeck, thickness $382 \mathrm{ft}(116.4 \mathrm{~m})$.

*NW Nineacre Wood, near Mountfield, Sussex, TQ/ 636 220, 1" 303, Purbeck.

OM Osmington Mills, Dorset, 1" 342, Purbeck.

PC Poxwell Road Cutting, Dorset. SY/7422 8354, 1" 342, Purbeck.

${ }^{*} \mathrm{Pe} \quad$ Penshurst Borehole, 1897, Kent, TQ/5480 4525, $1^{\prime \prime} 287$, Hastings Beds to $552 \mathrm{ft}$ (168 m), Purbeck Beds to $1114 \mathrm{ft} 4$ in $(339.6 \mathrm{~m})$. 
PO Portland, Dorset, 1" 343, Lower Purbeck.

*PO Portsdown No. 1 Borehole, Hampshire, SU/638 055,1 " 316, Purbeck and Wealden.

*PQ Philpott's Quarry, West Hoathly, Sussex, TQ/ 355 322, 1" 302, Grinstead Clay, Lower Tunbridge Wells Sand.

Pq Poxwell Quarry, Dorset, SY/743 835, 1" 342, Portland Beds.

PS Pluckley Station, Kent, TQ/9145 4262, 1" 288, Upper Weald Clay.

${ }^{*}$ Pt Penshurst Borehole, 1938, Kent, TQ/542 443, 1" 287, Ashdown Beds to $437 \mathrm{ft}(133.2 \mathrm{~m})$, Purbeck to $998 \mathrm{ft}$. (304.2 m).

PU Portesham Quarry, Portesham, Dorset, SY/6100 8592, 1" 327, Purbeck-Portland transition.

${ }^{*}$ PY Pevensey (Shallow) boreholes 1, 2, 4, 8, Sussex, 1. TQ/6348 0616, 2. TQ/6077 0456, 4. TQ/6214 0664, 8. TQ/6769 0563, Lower Weald Clay and Tunbridge Wells Sand.

Pevensey No. 1 (Deep) Borehole, 1938, Sussex, TQ/6264 0532, 1" 319, Base of Weald Clay to Portland at $754 \mathrm{ft}$.

${ }^{*}$ Rd Ringwould Borehole, 1955, Kent, TR/3529 4812, 1" 290, Upper Weald Clay.

${ }^{*} \operatorname{Re} \quad$ Ripe Borehole, near Hailsham, Sussex, TQ/5059 $1052,1^{\prime \prime} 319$, Weald Clay to about $210 \mathrm{~m}$.

Ri Ridgeway, Dorset, SY/671 851, 1" 342, Purbeck.

Ru Rudgewick, near Haslemere, Sussex, TQ/087 $334,1^{\prime \prime} 301$, Lower Weald Clay.

SB Sandown Bay, Isle of Wight, SZ/615 851, 1" 331, Weald Shales.

Sb Southborough, Kent, 1" 287, Tunbridge Wells Sand.

SC Shepherd's Chine, Isle of Wight, SZ/446 798, 1" 344 , Weald Shales.

Se Sharpthorne Pit, TQ/374 329, 1" 302, Upper Grinstead Clay.

SF Smokeham Farm, Tunbridge Wells, Kent, 1" 303, Grinstead Clay.

Sh Shotover Common, Oxfordshire, 1" 237, Shotover Ironsands.

SL St. Leonards, Sussex, 1" 320, Wadhurst Clay.

SO South Oving, Bucks., SP/785 215, 1" 219, Lower Purbeck.

*So Southwater Brick and Tile Works, Sussex, TQ/ $15862580,1 "$ "302, Lower Weald Clay.

ST Sevenoaks Tunnel, Kent, TQ/535 515, 1" 287, Weald Clay.

St Sandpit Wood, Newhouse, Kent, TQ/858 356, 1" 304, Wadhurst Clay.

SW Sweet Willow Wood Pumping Station, No. 6 Borehole, Bexhill, TQ/709 103, 1" 320, Wadhurst Clay.

*Sw Swindon, Wiltshire, 1" 252, Purbeck-Portland junction.
TB Tongham Water Bore, Farnham, Surrey, 1" 285 , Lower Weald Clay.

Ti Tilsden, near Cranbrook, Kent, TQ/789351 and 791 352, 1" 304, Wadhurst Clay.

TW Tunbridge Wells, Kent, 1" 303, Wadhurst Clay.

Up Upwey, Dorset, SY/66-84-, 1" 342, Purbeck.

VW Vale of Wardour, Wiltshire, 1" 298, Purbeck.

${ }^{*}$ Wa Warlingham Borehole, Surrey, 1956, TQ/3476 5719, 1" 286, Wealden and Purbeck 1047. $2150 \mathrm{ft}(319-655.3 \mathrm{~m})$.

WB Worbarrow Tout, Dorset, SY/8700 7960, 1" 342, Purbeck.

${ }^{*}$ Wd Warninglid Borehole, Slaugham, Sussex, 1966, TQ/2488 2701, 1" 302, Lower Weald Clay.

*We Westfield Borehole, Sussex, TQ/8204 1614, 1" 320, Wadhurst Clay.

*Wm Warnham Brick Pit, Sussex, TQ/173 346, 1" 302 , Lower Weald Clay.

WN White Nothe, Dorset, 1" 342, Lower Purbeck.

*WP Wadhurst Park Nos. 1-3 boreholes, Sussex, No. 1 TQ/6325 2911; No. 26308 2920; No. 3 6903 2902, 1" 303, Wadhurst Clay complete.

WW West Weare Cliff, Portland, Dorset, SY/681 720, 1" 342, Portland Beds.

Wy Wateringbury, near Maidstone, Kent, TQ/685 534, 1" 288, Upper Weald Clay.

Ya Yalding Railway Cutting, near Maidstone, Kent, 1" 288, Weald Clay.

\section{REFERENCES}

Alexander, C. I. 1933. Shell structure of the ostracode genus Cytheropteron and fossil species from the Cretaceous of Texas, J. Paleont., Wisconsin, 7, 181-214. pls. 25-27.

Allen, P. 1976. Wealden of the Weald: a new model. Proc. Geol. Ass. London, 86 (4), 389-437.

Allen, P. 1981. Pursuit of Wealden models. J. geol. Soc. London, 138, 375-405.

Allen, P. and Keith, M. L. 1965. Carbon isotope ratios and palaeosalinities of Purbeck-Wealden carbonates. Nature, London, 208, 1278-80.

Anderson, F. W. 1932. Phasal deposition in the Middle Purbeck Beds of Dorset. Rep. British Association, London, (for 1931), 379-80.

Anderson, F. W. 1939. Wealden and Purbeck Ostracoda. Ann. Mag. nat. Hist, London, (12), 3, 291-310, pls. XII \& XIII.

Anderson, F. W. 1940. Ostracod zones in the Wealden and Purbeck beds. Adv. Sci., London, 1, 259.

Anderson, F. W. 1941. Ostracods from the Portland and Purbeck Beds at Swindon. Proc. Geol. Ass., London, 51, 373-84, pls. 18-19.

Anderson, F. W. 1947. Ostracod zones (p. 124), Purbeck ostracods (pp. $129 \&$ 130, Fig. 28.), Wealden ostracods (p. 151, Fig. 34). In Arkell, W. J., The Geology of the Country around Weymouth, Swanage, Corfe \& Lulworth, Mem. geol. Surv. Gt. Brit. 
Anderson, F. W. 1953. Sur l'utilisation des microfaunes d'ostracodes dans la stratigraphie precise du passage Jurassique-Cretacé (Facies Continentaux). In Grekoff, N., Révue de l'Institut français du Pétrole et Annales de Combustibles liquides, Paris, 8 (7), 362-379.

Anderson, F. W. 1958. Purbeck Ostracod faunas, pp. 118-20, scopiques a l'étude d'échantillons de sondages. C. $R$. Congrès Cent. Soc. Inst. Min. France, Paris, Ri 2, 415-24.

Anderson, F. W. 1958. Purbeck Ostracod faunas. pp. 118-20, 127-29. In Wilson, V., Welch, F. B. A., Robbie, J. A. \& Green, G. W., Geology of the Country around Bridport and Yeovil. Mem. geol. Surv. Gt. Brit.

Anderson, F. W. 1958. Palaeontology and Stratigraphy of the Wealden and Purbeck, pp. 9-17, in Taitt, A. H. \& Kent, P. E., Deep Boreholes at Portsdown (Hants) and Henfield (Sussex), British Petroleum Co. Ltd.

Anderson, F. W. 1962. Correlation of the Upper Purbeck Beds of England with the German Wealden. Liverpool \& Manchester Geological Journal, Liverpool, 3, 21-32.

Anderson, F. W. 1963. Ostracod faunas in the Weald Clay, pp. 16-19, Fig. 7. In Worssam, B. C., Geology of the Country around Maidstone. Mem. geol. Surv. Gt. Brit.

Anderson, F. W. 1966. New genera of Purbeck and Wealden Ostracoda. Bull. Br. Mus. nat. Hist., Geol., London, 11, 435-46, figs. 1-30.

Anderson, F. W. 1966. Ostracod faunas in the Wealden, pp. 82-88. In Shephard-Thorn, E. R., Smart, J. G. O., Bisson, G. \& Edmonds, E. A., Geology of the Country around Tenterden, Mem. Geol. Surv. Gt. Brit.

Anderson, F. W. 1967. Ostracods from the Weald Clay of England. Bull. geol. Surv. Gt. Brit., No. 27, 237-69, pls. XVI-XIX.

Anderson, F. W., Bazley, R. A. B. \& Shephard-Thorn, E. R. 1967. The sedimentary and faunal sequence of the Wadhurst Clay (Wealden) in boreholes at Wadhurst Park, Sussex. Bull. geol. Surv. Gt. Brit., No. 27, 171-235, fig. 4, pls. IX-XV.

Anderson, F. W. 1968. Ostracod faunas in the Weald Clay, pp. 27-30, 56, Fig. 2. In Thurrell, R. G., Worssam, B. C. \& Edmonds, E. A., Geology of the Country around Haslemere, Mem. geol. Surv. Gt. Brit.

Anderson, F. W. 1969. Purbeck ostracod zones and Wealden ostracods, pp. 16-18. In Dines, H. G., Buchan, S., Holmes, S. C. A. \& Bristow, C. R., Geology of the Country around Sevenoaks and Tonbridge. Mem. geol. Surv. Gt. Brit.

Anderson, F. W. 1971. Appendix B. The sequence of Ostracod faunas in the Wealden and Purbeck of the Warlingham Borehole, pp. 122-38. In Worssam, B. C. \& Ivimey-Cook, H. C., The Stratigraphy of the Geological Survey Borehole at Warlingham, Surrey. Bull. geol. Surv. Gt. Brit. No. 36.

Anderson, F. W. \& Bazley, R. A. B. 1971. The Purbeck Beds of the Weald (England). Bull. geol. Surv. Gt. Brit. No. 34, Part II, The Ostracods, 27-173, figs. 6-9, pls. V-XXIII.

Anderson, F. W. 1973. The Jurassic-Cretaceous transition; the non-marine ostracod faunas, pp. 101-110, fig. 1. In The Boreal Lower Cretaceous, Ed. by Casey, R. and Rawson, P. F., Geol. Journal, Special Issue No. 5, Liverpool.

Anderson, F. W. 1975. Appendix 2, The Sequences of Ostracod faunas in the Wadhurst Clay of the Cooden Borehole, pp. 20-23, Fig. 4, In Lake, R. D., The Stratigraphy of the Cooden Borehole near Bexhill, Sussex, Rep. Inst. Geol. Sci., London, No. 75/12, 23 pp.

Austen, J. H. 1852. A guide to the Geology of the Isle of Purbeck and the South-West coast of Hampshire. 20 pp. W. Shipp, Blandford.
Barker, D. 1966(a) Ostracods from the Portland Beds of Dorset, Bull. Br. Mus. nat. Hist., Geol., London, 11, 44757, pls. 1-6.

Barker, D. 1966(b). Ostracods from the Portland and Purbeck Beds of the Aylesbury district. Bull. Br. Mus. nat. Hist., Geol., London, 11, 459-87, pls. 7-9.

Barker, D. 1975. In Barker, D., Brown, C. E., Bugg, S. C. \& Costin, J. Ostracods, Land plants, and Charales from the basal Purbeck Beds of Portesham Quarry, Dorset, Palaeontology, London, 18 (2), p. 423.

Bassiouni, M. A. 1974. Paranotacythere n.g. (Ostracoda) aus den Zeitraum Oberjura bis Unterkreide (Kimmeridgium bis Albium) von Westeuropa. Geologisches Jahrbuch, Hannover. Reihe, A., 17, 3-111.

Bate, R. H. 1965. Freshwater Ostracoda from the Bathonian of Oxfordshire. Palaeontology, London, 8, 749-59, pls. 109111.

Bosquet, J. 1852. Description des Entomostracés fossiles des terrains tertiares de la France et de la Belgique. Mém. couron. Acad. Roy. Belg., Bruxelles, 24, 1-42.

Brady, G. S. \& Robertson, D. 1885. In Jones, T. R., On the Ostracoda of the Purbeck Formation with notes on the Wealden species. Quart. J. Geol. Soc. London, 41, 311-53.

Branson, C. C. 1936. New names for a Morrison Ostracode genus. J. Paleont. Chicago, 10, 323.

Christensen, O. B. 1963. Ostracods from the Purbeck-Wealden Beds in Bornholm. Dansk. geol. Unders., Copenhagen, 11, 7-58.

Christensen, O. B. 1968. Some deposits and microfaunas from the Upper Jurassic in Scania. Sver. geol. Unders. Arsb., Stockholm, 62 (3), 3-46. (Afh. ser. C. NR 632).

Clements, R. G. 1973. On Timiriasevia punctata Clements sp. nov. Stereo-Atlas Ostracod Shells, Leicester, 1, 69-76.

Cornuel, J. 1848. Description de nouveaux fossiles microscopiques du terrain cretacé inférieur du Department de la Haute-Marne, Mém. Soc. géol. France, Paris, 3, 24.

Donze, P. 1960. Les formations du Jurassiques terminal dans la partie NO de l'île d'Oléron (Charente-Maritime). Trav. Lab. Geol. Lyon, 5, 5-30.

Dunker, W. 1846. Monographie der norddeutschen Wealdenbildung, Braunschweig.

Falcon, N. L. \& Kent, P. E. 1960. Geological results of petroleum exploration in Britain, 1945-57. Mem. geol. Soc. Loindon, No. 2.

Fitton, W. H. 1836. Observations on some of the strata between the Chalk and the Oxford Oolite, in the south-east of England. Trans. geol. Soc. London, (2), 4, 103-388.

Forbes, E. 1855. In Lyell, C., Manual of Elementary Geology, 5 th Edit. London.

Galeeva, L. I. 1955. Ostrakody melovykh otlozheniy monogolskoy Narodnoy Respubliki (Ostracods from the Cretaceous deposits of the People's Republic of Mongolia). Moscow, 1-95.

Harbort, E. 1907. Ein geologisches Querprofil durch die Kreide-Jura-und Triasformation des Bentheim-Isterberger Sattels. Festschrifi A. von Koenen, Stuttgart, 471-515.

Howitt, F. 1964. Stratigraphy and structure of the Purbeck inliers of Sussex (England), Quart. J. geol. Soc. London, 120, 77-113.

Jones, T. R. 1878. Notes on some fossil bivalved Entomostraca. Geol. Mag. London, (2), 5, 100-110, pl. 3.

Jones, T. R. 1878. On the Wealden Entomostraca. Geol. Mag. London, (2), 5, 277-8. 
Jones, T. R. 1880. Lettre Sur le Calcaire à Cypris du Boulonnais. Bull. Soc. géol. France, Paris (3), 8, 615-6.

Jones, T. R. 1885. On some fossil Entomostraca from the Purbeck formation at Boulogne, Proc. Geol. Ass., London, 8, 54-9.

Jones, T. R. 1885. On the Ostracoda of the Purbeck Formation; with notes on the Wealden species. Quart. J. geol. Soc. London, 41, 311-53.

Jones, T. R. 1888. Ostracoda from the Weald Clay of the Isle of Wight, Geol, Mag., London (3), 5, 534-9.

Jones, T. R. 1894. On the Rhaetic and some Liassic Ostracods of Britain. Quart. J. geol. Soc. London, 50, 156-69.

Lake, R. D. \& Holliday, D. W. 1978. Purbeck Beds of the Broadoak Borehole, Sussex, pp. 1-12. In Broadoak Borehole, Sussex. Rep. Inst. Geol. Sci., London, No. 78/3.

Lamplugh, G. W., Kitchen, F. L. \& Pringle, J. 1923. The concealed Mesozoic rocks in Kent. Mem. geol. Surv. Gt. Brit.

Laurencich, L. 1957. Stillina, a new genus of Cretaceous Ostracoda, J. Paleont. Tulsa, 31 (2), 455-7.

Ljubimova, P. S. 1955. Ostracods from Mesozoic sediments of the Volga and Ural region. Trud. vses, neft.-nauch. issled. geol. Inst. (VNIGRI), Leningrad, 84, 1-189, pls. 1-13.

Ljubimova, P. S. 1960. Ostracoda from Mesozoic and Cenozoic deposits of the West Siberian Lowland. VNIGRI. Leningrad, $160,1-427$.

Lyell, C. 1855. Manual of Elementary Geology, 5th Edit. London.

Mandelstam, M. I. 1947. Ostracoda from Middle Jurassic deposits of the Mangishlak Peninsula, Trud. vses. neft.nauch. issled. geol. Inst. (VNIGRI), Moscow, 239-259.

Mantell, G. 1844. Medals of Creation. 1 st Edition, London.

Martin, G.P. R. 1940. Ostracoden des norddeutschen Purbeck und Wealden. Senckenbergiana, Frankfurt am Main, 22, 275-361.

Martin, G. P. R. 1961. Eine marine Mikrofauna im Wealden von Emlich heim. Palaeontographica, Stuttgart, 116, 105-21.

Melville, R. V. 1982. Frederick William Anderson. Obituary. Ann. Rpt. Geol. Soc. London. 21-2.

Moos, B.in Wicher, C. A. 1959. Ein Beitrag zur Altersdeutung des Renconcavo Bahia (Brasilien). Geol. Jahrb., Hannover, 77, 35-57.

Morter, A. A. 1984. Purbeck-Wealden Beds Mollusca and their relationship to ostracod biostratigraphy, stratigraphical correlation and palaeoecology in the Weald and adjacent areas. Proc. Geol. Ass., London, 95, 217-234.

Neale, J. W. 1962. Ostracoda from the type Speeton Clay (Lower Cretaceous) of Yorkshire. Micropaleontology, New York, 8 (4), 425-84.

Oertli, H. J. 1957. Ostracodes du Jurassiques superieur du bassin de Paris (Sondage Vernon 1). Rév. Inst. franç. Pét. Ann. Comb. Liqu., Paris, 12 (6), 647-95.

Oertli, H. J. 1963. Ostracodes du 'Purbeckian' du Bassin Parisien. Rév. Inst. franç. Pétrole, Paris, 18 (1), 5-38.

Pinto, I. D. \& Sanguinetti, Y. T. 1962. A complete revision of the genera Bisulcocypris and Theriosynoecum (Ostracoda) with the world geographical and stratigraphical distribution. Bol. Esc. Geol. Porto Alegre, Pub. Esp. Univ. do Rio Grande do. Sol, Brazil, 4, 1-165. pl. 1-17.

Roemer, F. A. 1839. Die Versteinerungen des norddeutschen Oolithengebirges. Hannover.

Sohn, I. G. \& Anderson, F. W. 1964. The ontogeny of Theriosynoecum fittoni (Mantell). Palaeontology, London, 7 (1), $72-84$, figs. $1-4$, pl. 15 .
Sowerby, J. de C. 1836. In Fitton, W. H., Observations on some of the strata between the Chalk and the Oxford Oolite, in the South-east of England, Trans. geol. Soc. London, (2), 4. Appendix A, 335-49.

Sylvester-Bradley, P. C. 1941a. The shell structure of the Ostracoda and its application to their palaeontological investigation, Ann. Mag. nat. Hist., London, (2), 8, 1-33.

Sylvester-Bradley, P. C. 1941b. The Purbeck Beds of Swindon. Proc. Geol. Ass., London, 50, 349-72.

Sylvester-Bradley, P. C. 1949. The ostracod genus Cypridea and zones of the Middle and Upper Purbeckian.Proc. Geol. Ass., London, 60, 125-51.

Triebel, E. 1938. Ostracoden-untersuchungen 1.Protocythere und Exophthalmocythere, zwei neue Ostracoden-gattungen aus der Deutschen Kreide. Senckenbergiana, Frankfurt am Main, 20, 178-200.

Triebel, E. 1941. Zur Morphologie und Ökologie der fossilen Ostracoden. Senckenbergiana, Frankfurt am Main, 23, 294-400.

Walker, C. T. 1964. Depositional environment of the Purbeck Formation. Geol. Mag., Hertford, 101, 189.

Wolburg, J. 1959. Die Cyprideen N.W.-deutschen Wealden. Senck. Leth. Frankfurt am Main, 40, 223-315.

Wolburg, J. 1962. Die leitenden Ostracoden des nordwestdeutchen Wealden. In Simon, W. \& Bartenstein, H. Leitfossilien der Mikropalëontologie, Berlin, 204-24.

\section{APPENDIX}

The primary reason for the preparation of this and previous studies of Purbeck and Wealden ostracods has been the need to find a method of correlation of these variable sequences, not only within the Wealden area, but also into Hampshire, Dorset and beyond. To this end, numerous surface exposures and boreholes have been examined in Purbeck and Wealden strata across southern England. Parts of these correlations have been published (e.g. Anderson, 1971, pl. VI), but the large format and complexity of the diagrams has meant that they are not easily reproduced for publication. They do, however, illustrate the primary evidence for the correlations derived from the identification of the ostracods whose identity and distribution are summarised above.

A number of the diagrams drafted by Dr. Anderson have been presented to the Geological Survey and can be consulted by reference to the Biostratigraphy Research Group, British Geological Survey, Keyworth, Nottingham. Amongst these are diagrams showing:-

A. Sequence of Faunicycles in the Purbeck Beds (a), Portland to Cinder Beds.

Nineteen complete sequences spanning the Purbeck Beds in Dorset, Hampshire and the Weald are illustrated and correlated by Faunicycles. The sections are to scale and show some lithological detail. Difficulties in the nomenclature of the finer sediments (i.e. shales, mudstones, marls, siltstones and clays) are not resolved and these are all shown by one ornament. The 'limestones' range from calcareous mudstones to fragmental shell beds. Gypsum and/or anhydrite, though mainly found in the Ridgeway and Stair Faunicycles, also occur sporadically at higher levels. The 'Broken Beds' of the Dorset 
coast are here equated with the main Gypsum Beds of Sussex and are found in boreholes in Hampshire.

B. Sequence of Faunicycles in the Purbeck (b), above the Cinder Beds.

The Purbeck Beds above the Cinder Beds in the same 19 sequences are treated in a similar fashion. Except near Ridgeway, sandstones are rare in the western part of the basin unlike in the east where coarser sediments are common, particularly in the Upper Purbeck.

C. The Portland-Purbeck Transition.

Details of the lithostratigraphy, ostracods and bivalves of sections at Bugle Pit, N. Whitechurch and Warren Farm, near Aylesbury; Swindon (Wilts.) and Portesham, Dorset.

These beds are only seen near the western shore. There is a lower sequence of mainly Portland-type sediments with Myophorella, Liostrea and ostracods belonging to the genus Macrodentina but including some less saline episodes with species of Fabanella and even, though rarely, with Cypridea spp. This is followed by more typical Lower Purbeck sediments with Fabanella as the dominant ostracod genus and with species of Cypridea rather more common.

D. The stratigraphical distribution of ostracod species in the Purbeck and Wealden of England.
This shows the ostracod species as a percentage of the total ostracod fauna. C-phase and S-phase species are both shown (unlike Figs. 3 and 4 in this paper). The predominance of $\mathbf{S}$-phase species in both the early parts of the Purbeck and latest Wealden is clearly seen.

E. Sequence of ostracod faunas in the Wadhurst Clay of Sussex and Surrey.

A detailed correlation between the Wadhurst Park, Westfield, Cooden, Little Maxfield, Freshfield Lane and Warlingham boreholes showing graphically the percentage of S-phase species as a percentage of the total ostracods, and the C-phase species as a percentage of total C-phase ostracods.

Note the marked faunal change between the Fairlight and Lindfield Faunicycles.

F. Sequence of ostracod faunas in the Lower Weald Clay (Henfield phase) of Sussex and Surrey.

A detailed correlation between the Ripe, Hailsham, Warlingham and Cuckfield boreholes and Clock House and Warnham pits showing graphically the percentage of S-phase species as a percentage of the total ostracods and the $\mathbf{C}$-phase species as a percentage of the $\mathbf{C}$-phase ostracods. This shows the successive replacement of $C$. dorsispinata and C. tuberculata of the basal Wealden by $C$. pumila and $C$. marina and these by $C$. clavata in the highest parts of the Weald Clay. 


\section{Explanation of Plate 1}

All the specimens figured within each plate are in the collection of the British Geological Survey, at Keyworth, Nottinghamshire. Earlier citations of Mik(M) numbers often include the three number suffix 001 . This is here omitted as all these specimens are alone on single cell slides.

Plates, but not the figures within each plate, are ordered by first appearance of species.

Fig. 1. Wolburgia visceralis (Anderson), Mik(M) 722; holotype; length $0.67 \mathrm{~mm}$, height $0.36 \mathrm{~mm}$; Town Gardens Quarry, Swindon, Wiltshire.

p. 38

Fig. 2. Macrodentina rugulata (Jones), Mik(M) 3290; length $0.77 \mathrm{~mm}$, height $0.46 \mathrm{~mm}$; Warren House Farm, Stewkley, Buckinghamshire.

p. 35

Fig. 3. Macrodentina transiens (Jones), Mik(M) 3291; length $0.63 \mathrm{~mm}$, height $0.365 \mathrm{~mm}$; Warren House Farm, Stewkley, Buckinghamshire.

p. 36

Fig. 4. Macrodentina retirugata (Jones), Mik(M) 720) length $0.88 \mathrm{~mm}$, height $0.50 \mathrm{~mm}$; Town Gardens Quarry, Swindon, Wiltshire.

p. 35

Fig. 5. Paraschuleridea buglensis Barker, Mik(M) 724; holotype; length $0.75 \mathrm{~mm}$, height $0.40 \mathrm{~mm}$; Town Gardens Quarry, Swindon, Wiltshire.

Fig. 6. Fabanella boloniensis (Jones), Mik(M) 4489; length $1.10 \mathrm{~mm}$, height $0.56 \mathrm{~mm}$; White Nothe, Dorset. p. 35

Fig. 7. Protocythere serpentina (Anderson), Mik(M) 723; holotype; length $0.70 \mathrm{~mm}$, height $0.40 \mathrm{~mm}$, Town Gardens Quarry, Swindon, Wiltshire.

p. 37

Fig. 8. Cypridea dunkeri dunkeri Jones, Mik(M) 738; length $0.84 \mathrm{~mm}$, height $0.52 \mathrm{~mm}$; Osmington Mills, Dorset.

p. 28

Fig. 9. Eoparacypris weedonensis Anderson, Mik(M) 3285; holotype; length $0.635 \mathrm{~mm}$, height $0.33 \mathrm{~mm}$; Netherfield Place No. 5 Borehole, Sussex.

p. 35

Fig. 10. Cypridea dunkeri carinata Martin, Mik(M) 3151; length $0.88 \mathrm{~mm}$, height $0.555 \mathrm{~mm}$; Mountfield No. 4 Borehole, Sussex.

p. 28

Fig. 11. Cypridea dunkeri papulata (Anderson), Mik(M) 737; holotype; length $1.04 \mathrm{~mm}$, height $0.66 \mathrm{~mm}$; Town Gardens Quarry, Swindon, Wiltshire.

p. 28

Fig. 12. Fabanella ansata (Jones), Mik(M) 4497; length 0.875 mm, height 0.495 mm; Kingsclere Borehole, Hampshire.

p. 35

Fig. 13. Cypridea tumescens tumescens (Anderson), Mik(M) 540; holotype; length $1 \cdot 39 \mathrm{~mm}$, height $0 \cdot 79 \mathrm{~mm}$; Friar Wadden, Upwey, Dorset.

p. 32

Fig. 14. Cypridea tumescens acrobeles Anderson, Mik(M) 3150; holotype; length $1.115 \mathrm{~mm}$, height $0.755 \mathrm{~mm}$; Mountfield No. 4 Borehole, Sussex.

p. 32

Fig. 15. Eocytheridea eusarca (Anderson), Mik(M) 725; holotype; length $1 \cdot 22 \mathrm{~mm}$, height $0.76 \mathrm{~mm}$; Town Gardens Quarry, Swindon, Wiltshire.

p. 34

Fig. 16. Cypridea tumescens praecursor Oertli, Mik(M) 3320; length $1.14 \mathrm{~mm}$, height $0.73 \mathrm{~mm}$; Mountfield No. 4 Borehole, Sussex.

p. 32

Fig. 17. Orthonotacythere rimosa Martin, Mik(M) 3272; length $0.565 \mathrm{~mm}$, height $0.33 \mathrm{~mm}$; Quainton, Buckinghamshire.

p. 36

Fig. 18. Cypridea dunkeri inversa Martin, Mik(M) 3152; length $0.905 \mathrm{~mm}$, height $0.62 \mathrm{~mm}$; Mountfield No. 4 Borehole, Sussex.

p. 28 

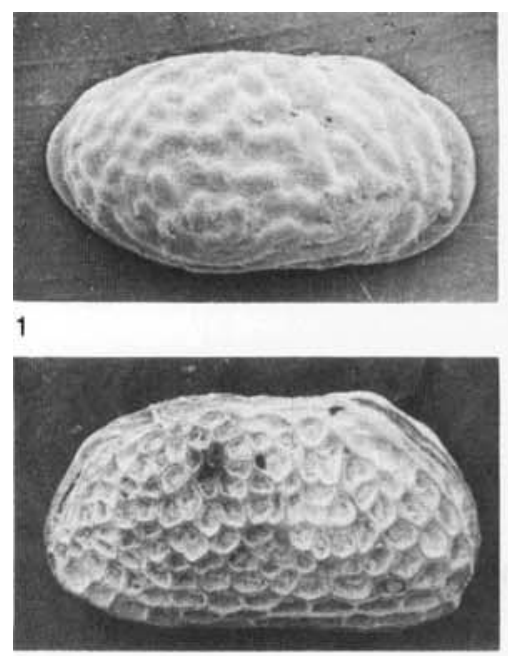

4

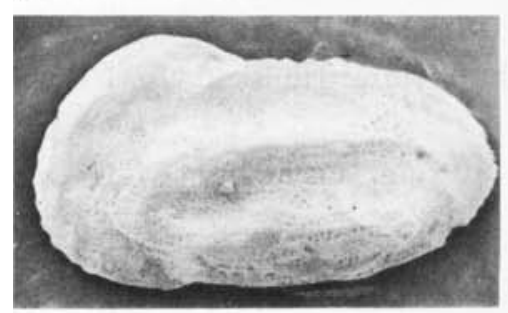

7

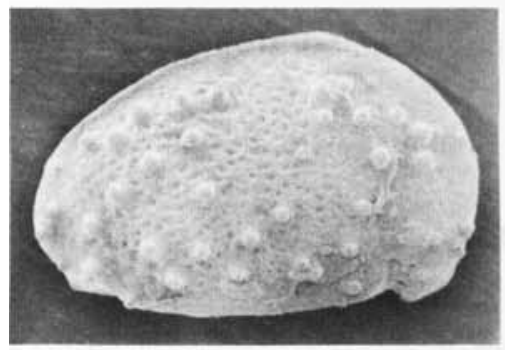

10

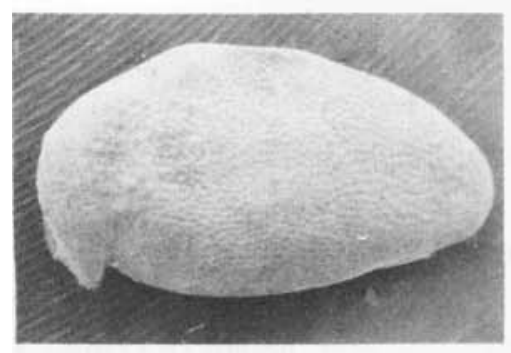

13

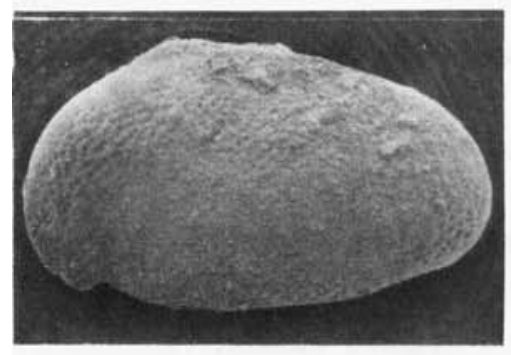

16

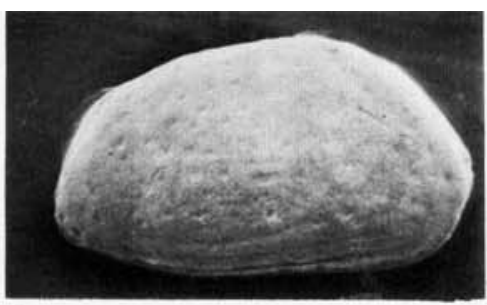

2

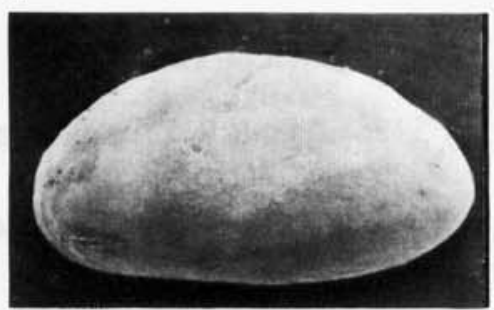

5

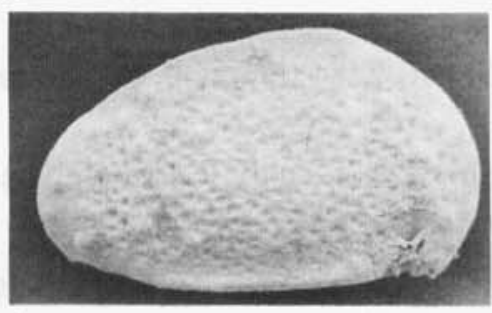

8

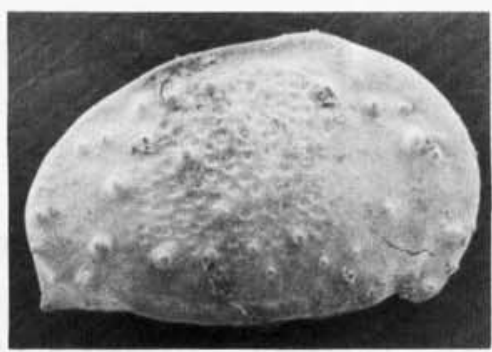

11

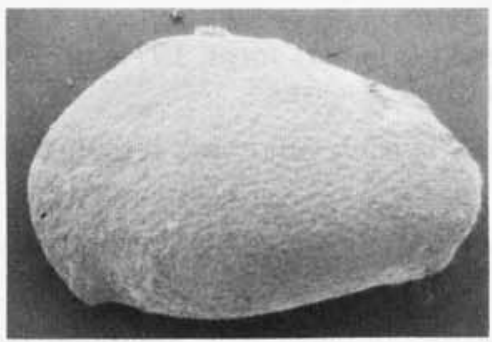

14

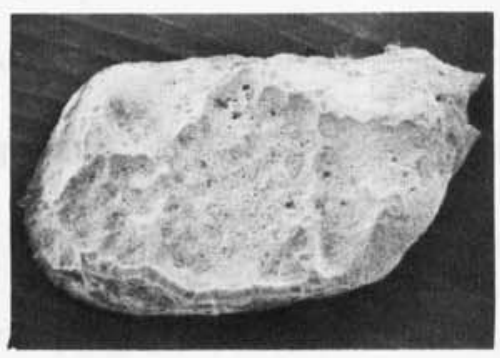

17

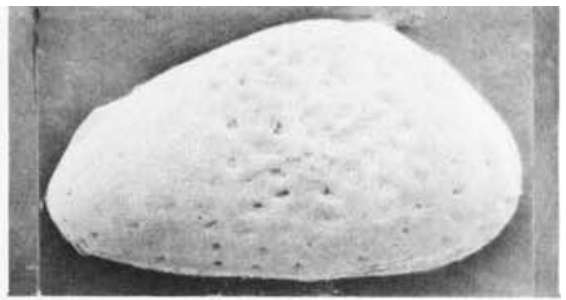

3

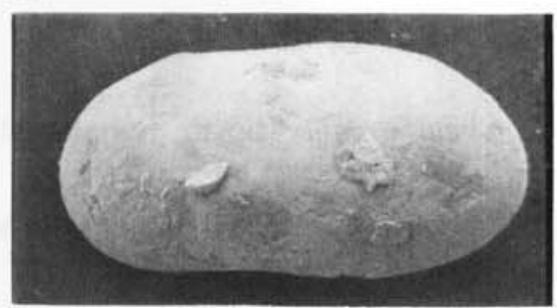

6

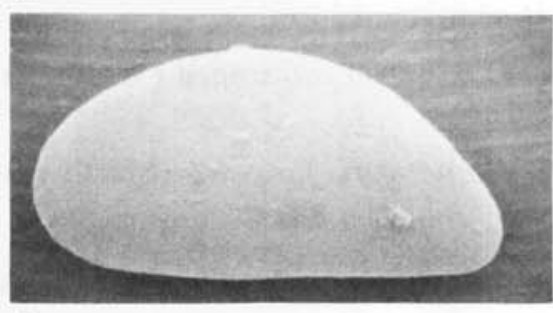

9

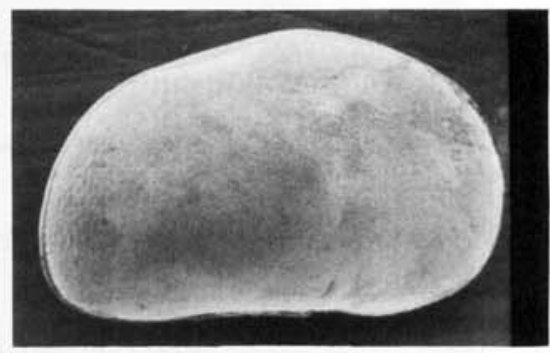

12

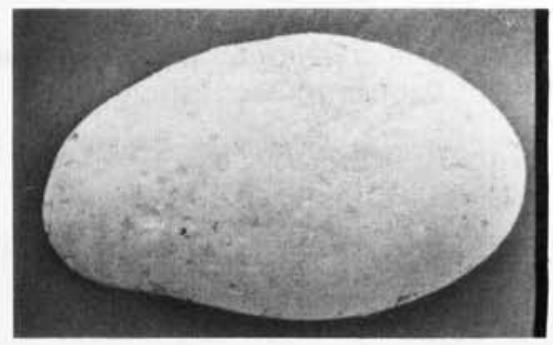

15

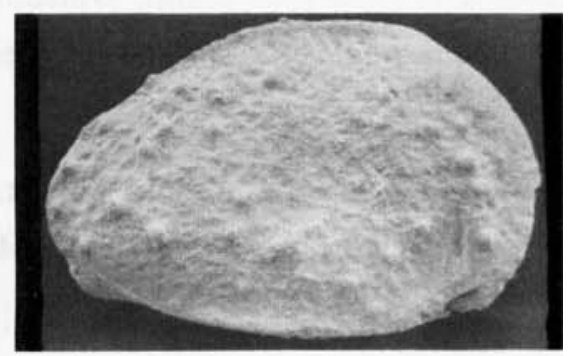

18 


\section{Explanation of Plate 2}

Fig. 1. Klieana alata Martin, female, Mik(M) 3275; length $0.55 \mathrm{~mm}$, height $0.375 \mathrm{~mm}$; Netherfield Place No. 5 Borehole, Sussex.

Fig. 2. Klieana alata Martin, male, Mik(M) 3276; length $0.64 \mathrm{~mm}$, height $0.4 \mathrm{~mm}$; Netherfield Place No. 5 Borehole, Sussex.

Fig. 3. Procytheropteron barkeri Anderson, Mik(M) 3305; topotype; length 0.44 mm, height $0.265 \mathrm{~mm}$; Weedon, Buckinghamshire.

Fig. 4. Damonella ellipsoidea (Wolburg), Mik(M) 2484; length 0.66 mm, height $0.4 \mathrm{~mm}$; Henfield No. 1 Borehole, Sussex.

Fig. 5. Rhinocypris jurassica (Martin), Mik(M) 3287; length 0.45 mm, height 0.25 mm; Osmington Mills, Dorset.

Fig. 6. Stenestroemia fragilis (Martin), Mik(M) 3289; length 0.61 mm, height 0.27 mm; Durlston Bay, Dorset.

Fig. 7. Damonella pygmaea (Anderson), Mik(M) 2482; holotype; length $0.51 \mathrm{~mm}$, height $0.30 \mathrm{~mm}$; Town Gardens Quarry, Swindon, Wiltshire.

Fig. 8. Theriosynoecum forbesi verrucosa (Jones), Mik(M) 3296; length $0.82 \mathrm{~mm}$, height $0.47 \mathrm{~mm}$; Ridgeway, Dorset.

Fig. 9. Theriosynoecum forbesi forbesi (Jones), Mik(M) 3294; length $0.78 \mathrm{~mm}$, height $0.495 \mathrm{~mm}$; Ridgeway, Dorset.

Fig. 10. Mantelliana wealdensis (Wolburg), male, Mik(M) 3220; length $1 \cdot 14 \mathrm{~mm}$, height $0 \cdot 665 \mathrm{~mm}$; Guestling No. 1 Borehole, Sussex.

Fig. 11. Cypridea peltoides peltoides Anderson (angular form, 1971, pl. 7, fig. 7), Mik(M) 3318; length 0.985 mm, height $0.66 \mathrm{~mm}$; Mountfield No. 5 Borehole, Sussex.

p. 30

Fig. 12. Cypridea primaeva Anderson, Mik(M) 736; holotype; length $0.85 \mathrm{~mm}$, height $0.55 \mathrm{~mm}$; Town Gardens Quarry, Swindon, Wiltshire.

p. 30

Fig. 13. Damonella buchaniana Anderson, Mik(M) 2483; holotype; length $0.46 \mathrm{~mm}$, height $0.3 \mathrm{~mm}$; Portsdown No. 1 Borehole, Hampshire.

Fig. 14. Scabriculocypris trapezoides Anderson, Mik(M) 727; holotype; length $0.565 \mathrm{~mm}$, height $0.37 \mathrm{~mm}$; Town Gardens Quarry, Swindon, Wiltshire.

Fig. 15. Mantelliana purbeckensis (Forbes), Mik(M) 2682; length $1 \cdot 125 \mathrm{~mm}$, height $0 \cdot 755 \mathrm{~mm}$; Kingsclere Borehole, Hampshire.

p. 36

Fig. 16. Cypridea peltoides eurygaster Anderson, Mik(M) 3033; holotype; length $1 \cdot 18 \mathrm{~mm}$, height $0 \cdot 88 \mathrm{~mm}$; Mountfield No. 4 Borehole, Sussex.

Fig. 17. Mantelliana cyrton Anderson, Mik(M) 3217; holotype; length $1.35 \mathrm{~mm}$, height $1.07 \mathrm{~mm}$; Mountfield No. 4 Borehole, Sussex.

Fig. 18 Mantelliana wealdensis (Wolburg), female, Mik(M) 3219; length $1.17 \mathrm{~mm}$, height $0.82 \mathrm{~mm}$; Netherfield Place No. 5 Borehole, Sussex. 

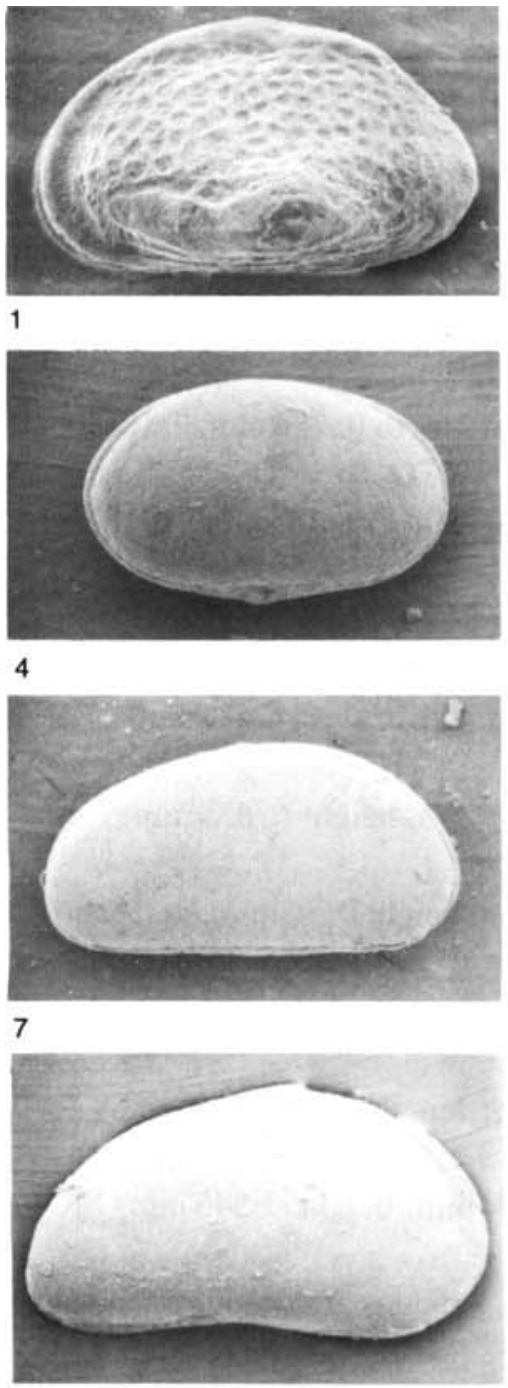

10

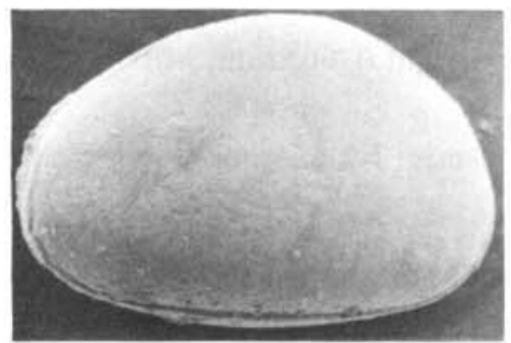

13

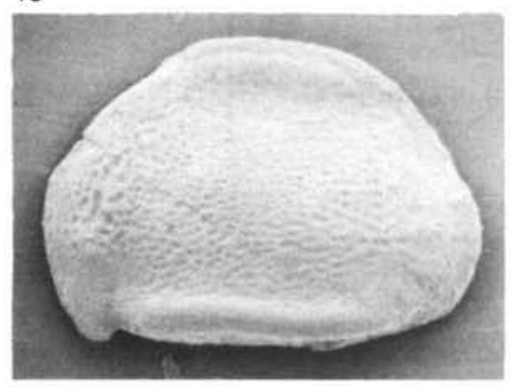

16

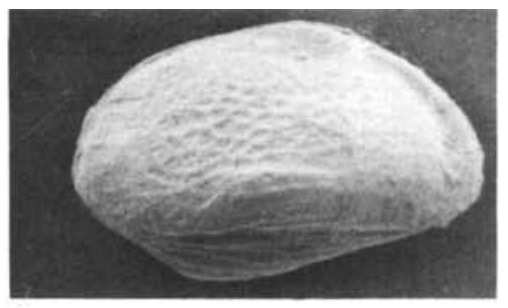

2

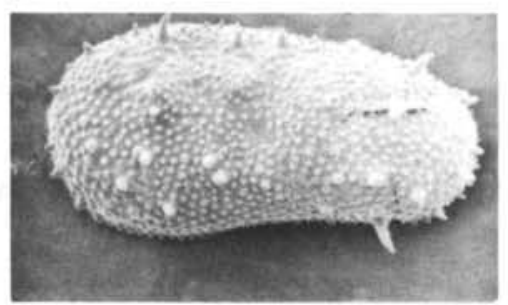

5

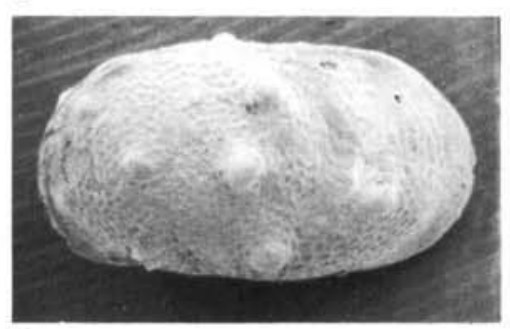

8

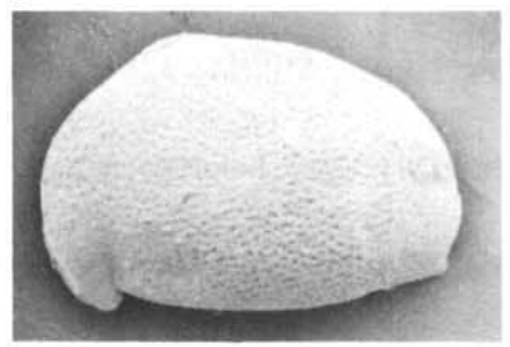

11

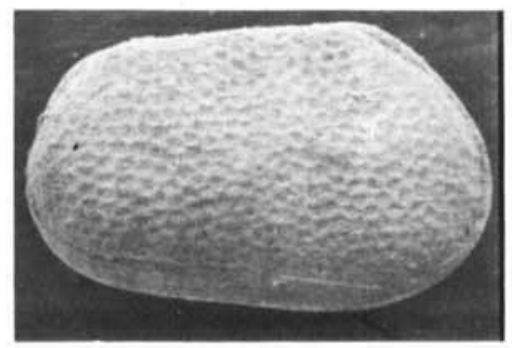

14

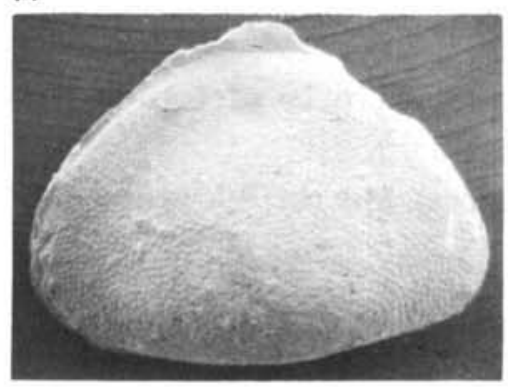

17
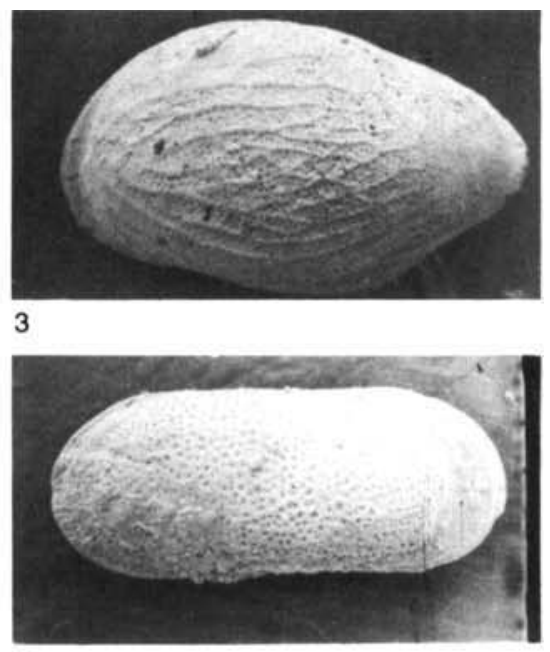

6

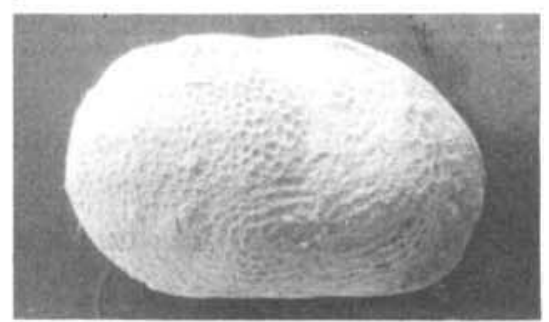

9

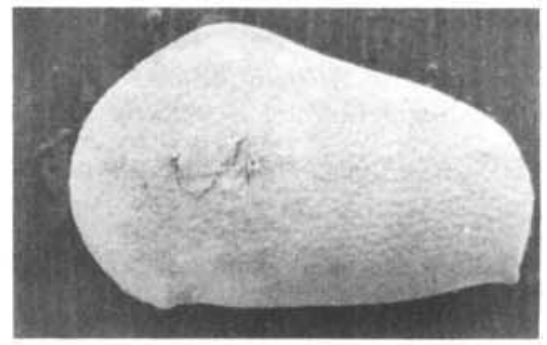

12
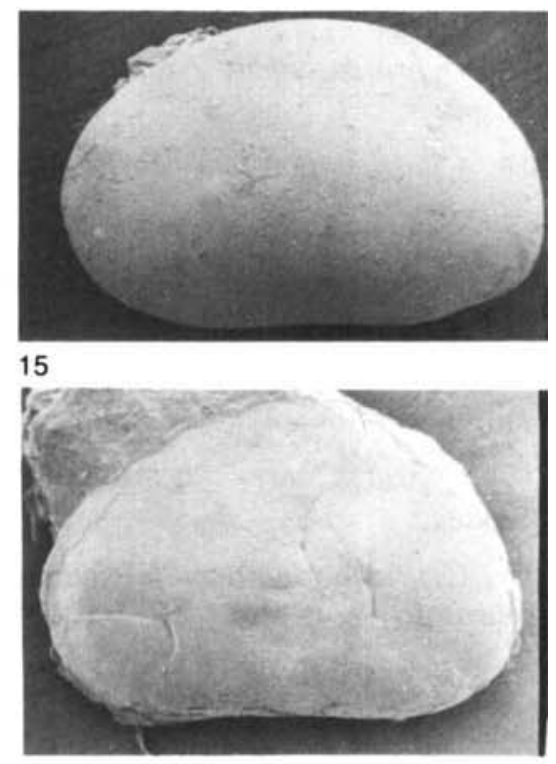

18 


\section{Explanation of Plate 3}

Fig. 1. Bisulcocypris striata striata (Martin), Mik(M) 3298; length 0.615 mm, height 0.35 mm; Chilcomb Down No. 1 Borehole, Hampshire.

p. 33

Fig. 2. Bisulcocypris striata monotuberculata Anderson, Mik(M) 3297; holotype; length $0 \cdot 735 \mathrm{~mm}$, height $0 \cdot 44 \mathrm{~mm}$; Kingsclere No. 1 Borehole, Hampshire.

Fig. 3. Pseudoparacypridopsis mountfieldensis Anderson, Mik(M) 3282; holotype; length 1.155 mm, height 0.63 mm; Chilcomb Down Borehole, Hampshire.

Fig. 4. Timiriasevia punctata Clements, Mik(M) 3322; length $0.52 \mathrm{~mm}$, height $0.31 \mathrm{~mm}$; Mountfield No. 4 Borehole, Sussex.

p. 38

Fig. 5. Orthonotacythere favulata Martin, male, Mik(M) 3273; length $0.54 \mathrm{~mm}$, height $0.31 \mathrm{~mm}$; Netherfield Place No. 5 Borehole, Sussex.

Fig. 6. Eoparacypris macroselina Anderson, male, Mik(M) 3288; length $1.385 \mathrm{~mm}$, height $0.635 \mathrm{~mm}$; Netherfield Place No. 3 Borehole, Sussex.

Fig. 7. Orthonotacythere favulata Martin, female, Mik(M) 3264; length $0.59 \mathrm{~mm}$, height $0.31 \mathrm{~mm}$; Netherfield Place No. 5 Borehole, Sussex.

p. 36

Fig. 8. Cypridea granulosa granulosa (J. de C. Sowerby), Mik(M) 517 ; lectotype; length $1 \cdot 15 \mathrm{~mm}$, height $0 \cdot 78 \mathrm{~mm}$; Vale of Wardour, Wiltshire.

p. 28

Fig. 9. Eoparacypris macroselina Anderson, female, Mik(M) 3281; holotype; length $2.02 \mathrm{~mm}$, height $1.04 \mathrm{~mm}$; Penshurst (1899) Borehole, Sussex.

p. 35

Fig. 10. Bisulcocypris dilatata Anderson, Mik(M) 3300; holotype; length $0.54 \mathrm{~mm}$, height $0.345 \mathrm{~mm}$; Mountfield No. 4 Borehole, Sussex.

p. 33

Fig. 11. Klieana dictyota Anderson, Mik(M) 3274; holotype; length 0.54 mm, height 0.365 mm; Penshurst (1938) Borehole, Sussex.

p. 35

Fig. 12. Cypridea granulosa protogranulosa Anderson, Mik(M) 3155; topotype; length $1.065 \mathrm{~mm}$, height $0.69 \mathrm{~mm}$; Netherfield Place No. 5 Borehole, Sussex.

p. 28

Fig. 13. Cypridea sagena Anderson, Mik(M) 3169; holotype; length $1.03 \mathrm{~mm}$, height $0.665 \mathrm{~mm}$; Milkhurst Wood, Sussex.

p. 31

Fig. 14. Cypridea lata lata Martin, Mik(M) 3172; length $1.04 \mathrm{~mm}$, height 0.68 mm; Nine Acre Wood, Sussex.

Fig. 15. Cypridea lata latissima Anderson, Mik(M) 3177; holotype; length $1.055 \mathrm{~mm}$, height $0.74 \mathrm{~mm}$; Kingsclere No. 1 Borehole, Hampshire.

p. 29

Fig. 16. Mantelliana cyrton Anderson, Mik(M) 3218; topotype; length $1 \cdot 28 \mathrm{~mm}$, height $0.915 \mathrm{~mm}$; Mountfield No. 4 Borehole, Sussex.

p. 36

†Fig. 17. Cypridea lata senilis Anderson, Mik(M) 3176; length $1.16 \mathrm{~mm}$, height $0.825 \mathrm{~mm}$; Guestling No. 3 Borehole, Sussex.

p. 29

Fig. 18. Cypridea granulosa fasciculata (Forbes), Mik (M) 390 ; †neotype; length $1 \cdot 15 \mathrm{~mm}$, height $0 \cdot 75 \mathrm{~mm}$; Vale of Wardour, Wiltshire.

tThis neotype was proposed by Anderson in 1971 (p.67), using a syntype of the original material of Cypridea granulosa. Although it is possible that this specimen was studied by Forbes there is no evidence that it is a syntype of his $C$. fasciculata. However, since 1971, definite syntypes determined by Forbes as $C$. fasciculata have been recognized in the B.G.S. collections. They are on a slab with numerous $C y p r i d e a$ (GSM 60264) recorded as from the Middle Purbeck Beds of Durlestone Bay, Dorset. 

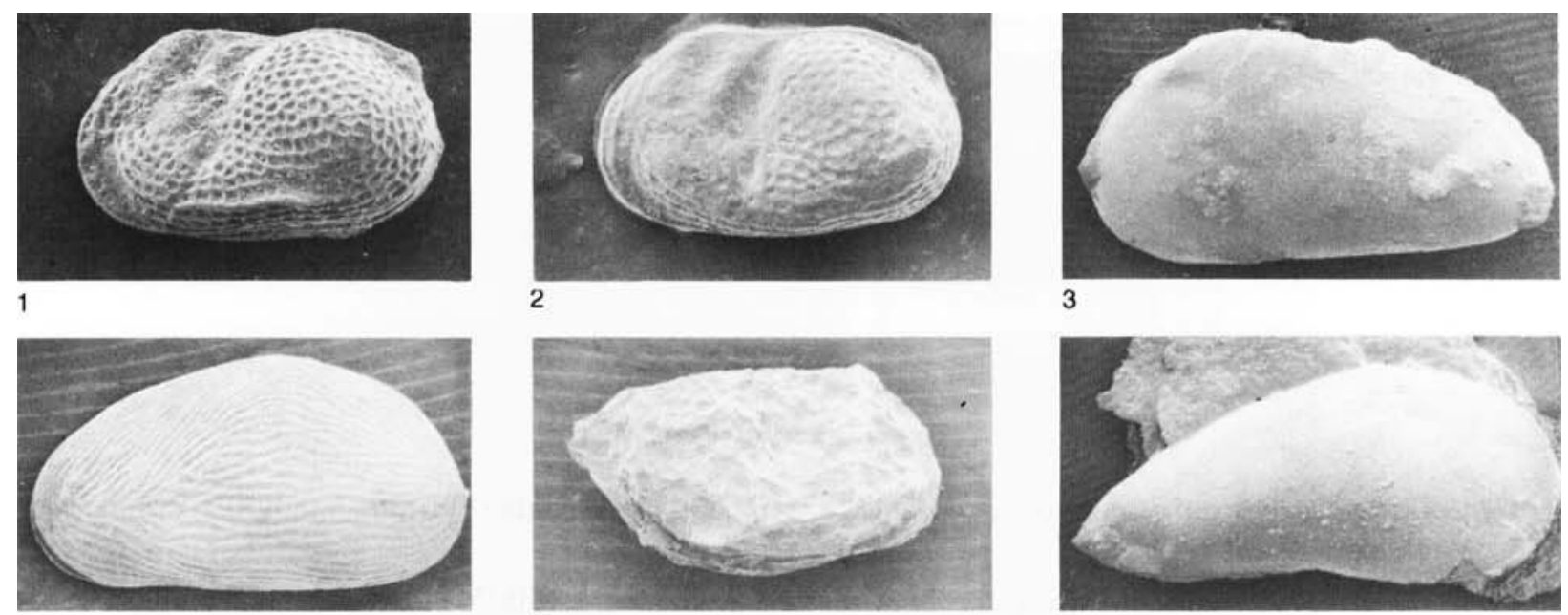

4

5
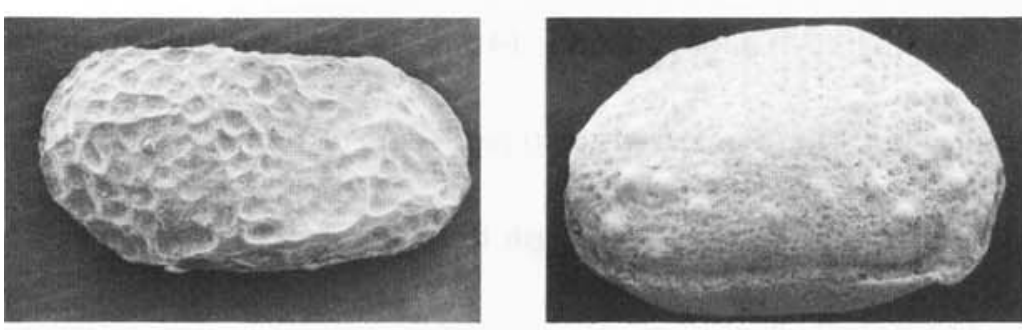

7

8

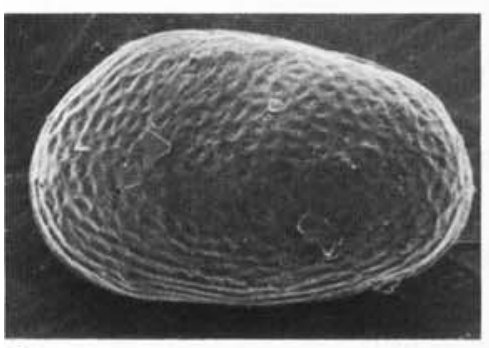

10

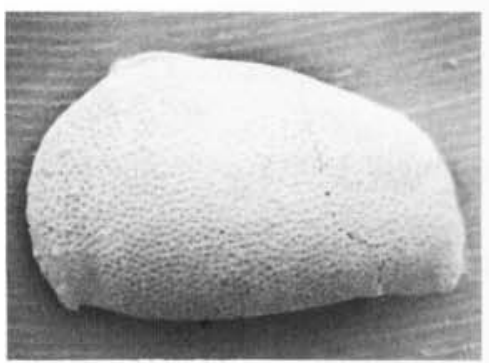

13

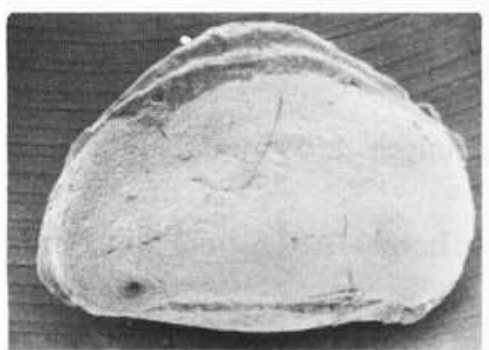

16

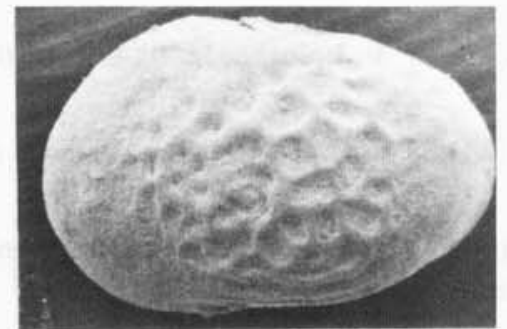

11

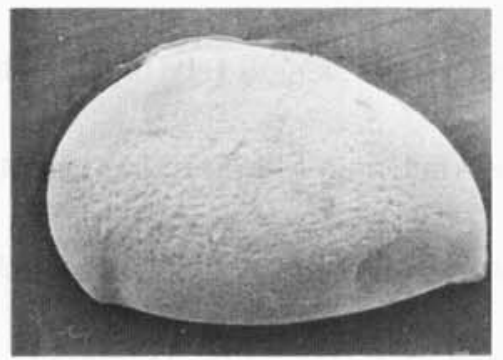

14

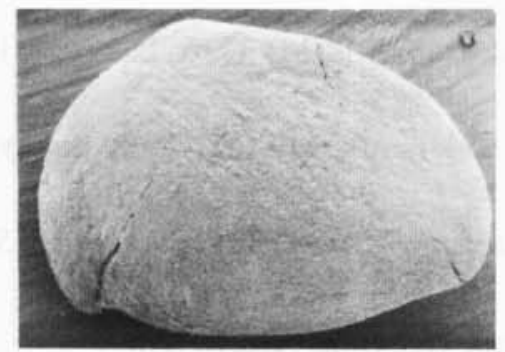

17

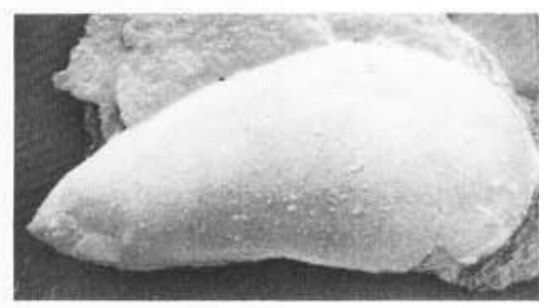

6

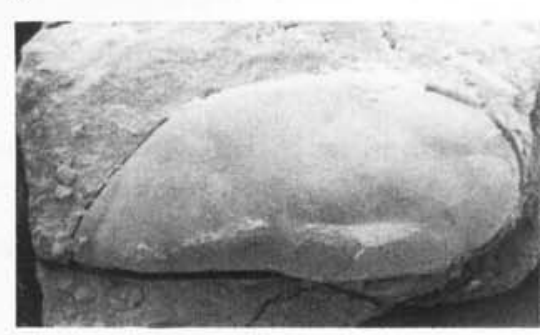

9

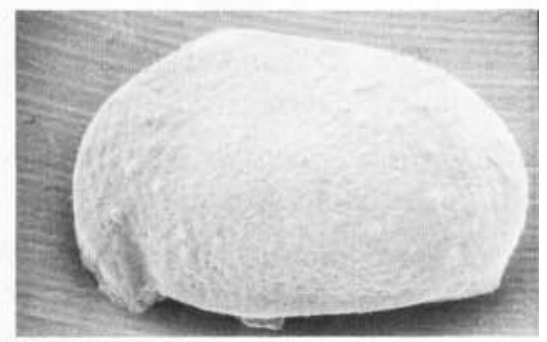

12

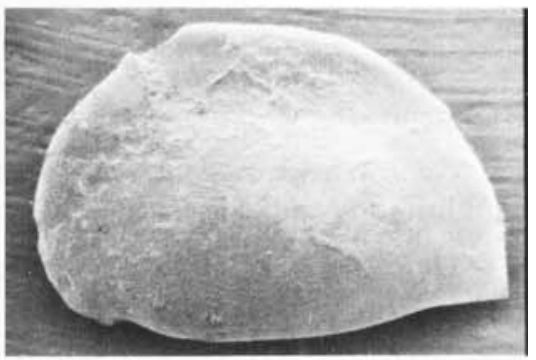

15

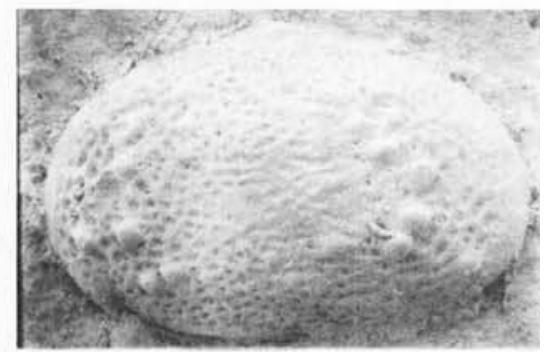

18 


\section{Explanation of Plate 4}

Fig. 1. Cypridea swanagensis ornata Anderson, Mik(M) 3162; holotype; length $0.96 \mathrm{~mm}$, height $0.645 \mathrm{~mm}$; Milkhurst Wood, Sussex.

p. 32

Fig. 2. Cypridea aemulans nom. nov. for C. acuta Anderson (non Moos), Mik(M) 3198; holotype; length 0.905 mm, height $0.545 \mathrm{~mm}$; Warlingham Borehole, Surrey.

p. 25

Fig. 3. Galliaecytheridea postsinuata Wolburg, male, Mik(M) 3263; length $1.14 \mathrm{~mm}$, height $0.62 \mathrm{~mm}$; Henfield No. 1 Borehole, Sussex.

Fig. 4. Orthonotacythere nodosaria Anderson, male; Mik(M) 3265; holotype; length $0.59 \mathrm{~mm}$, height $0.36 \mathrm{~mm}$; Mountfield No. 3 Borehole, Sussex.

p. 36

Fig. 5. Orthonotacythere nodosaria Anderson, female; Mik(M) 3266; length 0.52 mm, height 0.325 mm; Poxwell Road Cutting, Dorset.

Fig. 6. Orthonotacythere cineraria Anderson, Mik(M) 3268; holotype; length $0.575 \mathrm{~mm}$, height $0 \cdot 31 \mathrm{~mm}$; Poxwell Road Cutting, Dorset.

Fig. 7. Cypridea delicatula Anderson, Mik(M) 3170; holotype; length $1.06 \mathrm{~mm}$, height $0.705 \mathrm{~mm}$; Mountfield No. 3 Borehole, Sussex.

Fig. 8. Cypridea coelnothi Anderson, Mik(M) 3160; holotype; length $1.01 \mathrm{~mm}$, height $0.66 \mathrm{~mm}$; Netherfield Place No. 5 Borehole, Sussex.

Fig. 9. Galliaecytheridea postsinuata Wolburg, female, Mik(M) 3262 ; length $0.95 \mathrm{~mm}$, height $0.58 \mathrm{~mm}$; Lower Chicksgrove, Vale of Wardour, Wiltshire.

Fig. 10. Cypridea posticalis Jones, Mik(M) 1020; lectotype; length $1.085 \mathrm{~mm}$, height $0.69 \mathrm{~mm}$; Ridgeway, Dorset.

Fig. 11. Cypridea inaequalis Wolburg, Mik(M) 3192; length 1.08 mm, height 0.725 mm; Chilcomb Down Borehole, Hampshire.

Fig. 12. Cypridea swanagensis swanagensis Anderson, Mik(M) 3161; holotype; length $1 \cdot 08 \mathrm{~mm}$, height $0 \cdot 725 \mathrm{~mm}$; Milkhurst Wood, Sussex.

p. 32

Fig. 13. Cypridea penshurstensis Anderson, Mik(M) 3168; holotype; length $1.06 \mathrm{~mm}$, height $0.69 \mathrm{~mm}$; Chilcomb Down Borehole, Hampshire.

p. 30

Fig. 14. Cypridea dolabrata angulata Martin, Mik(M) 2126; length $1 \cdot 2 \mathrm{~mm}$, height $0 \cdot 83 \mathrm{~mm}$; Chilcomb Down Borehole, Hampshire.

Fig. 15. Scabriculocypris durlstonensis Anderson, Mik(M) 3215; holotype; length $1 \cdot 1 \mathrm{~mm}$, height $0 \cdot 8 \mathrm{~mm}$; Durlston Bay, Dorset.

p. 37

Fig. 16. Cypridea dolabrata dolabrata (Anderson), Mik(M) 533; holotype; length $1.05 \mathrm{~mm}$, height $0.74 \mathrm{~mm}$; Portsdown No. 1 Borehole, Hampshire.

p. 27

Fig. 17. Scabriculocypris durlstonensis Anderson, Mik(M) 3216; length $1 \cdot 15 \mathrm{~mm}$, height $0.815 \mathrm{~mm}$; Chilcomb Down Borehole, Hampshire.

Fig. 18. Cypridea dolabrata angulata Martin (gibbous variety, Anderson), Mik(M) 2127; length $1 \cdot 25 \mathrm{~mm}$, height $0.985 \mathrm{~mm}$; Chilcomb Down Borehole, Hampshire. 


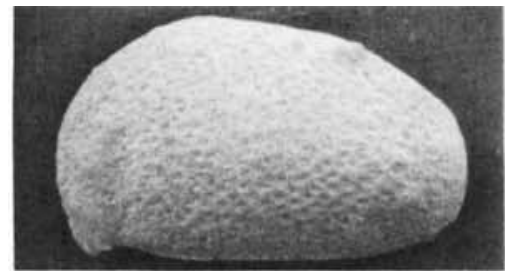

1

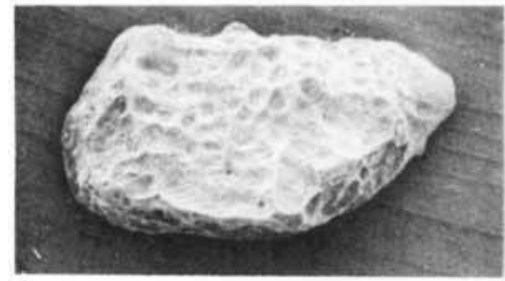

4

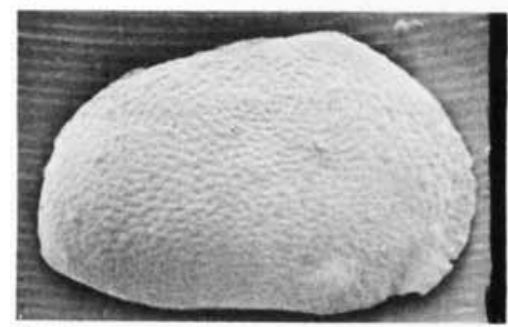

7

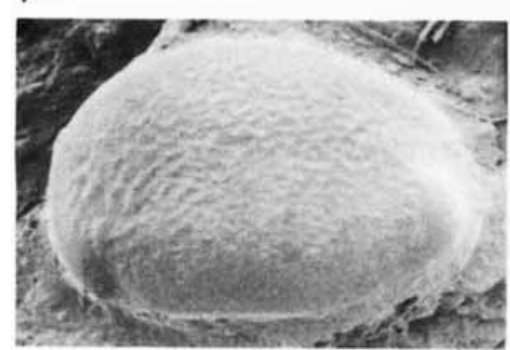

10

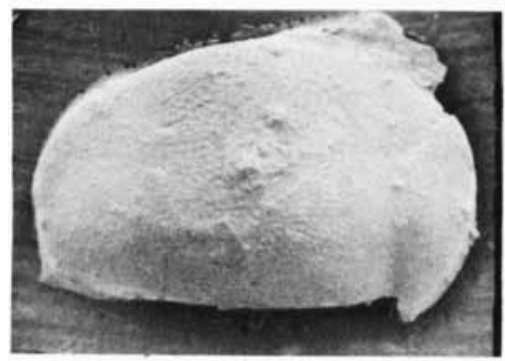

13

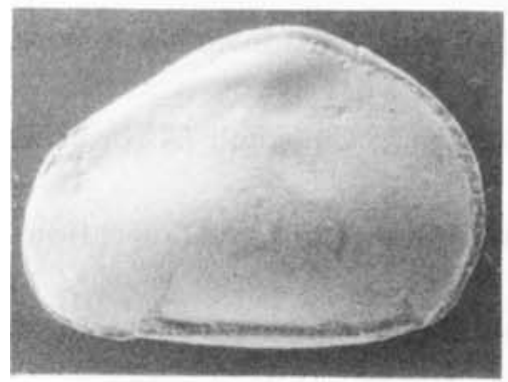

16

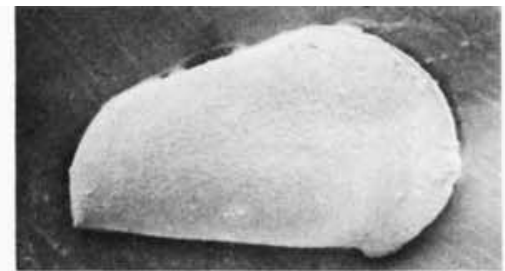

2

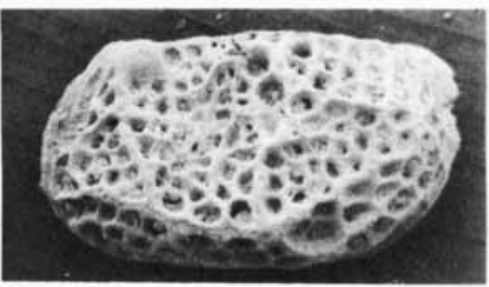

5

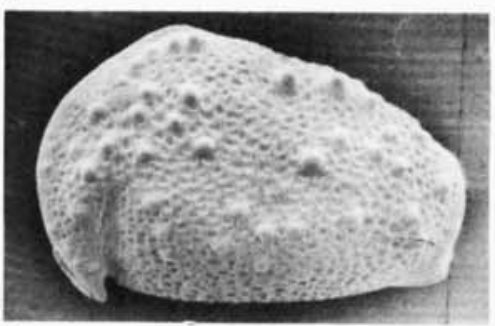

8

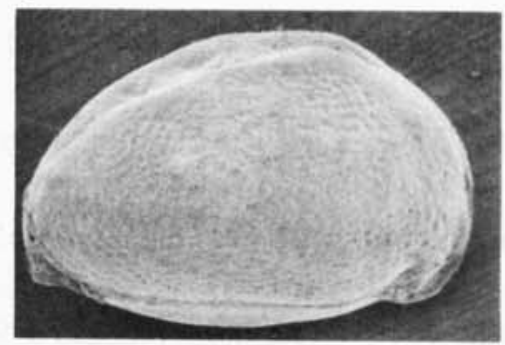

11

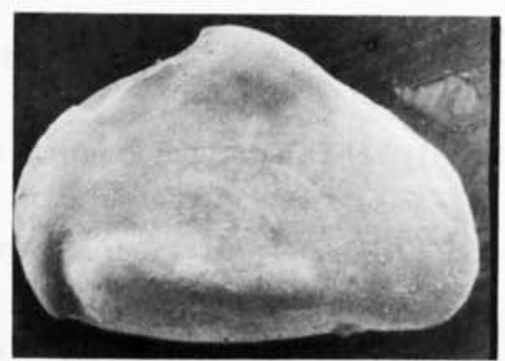

14

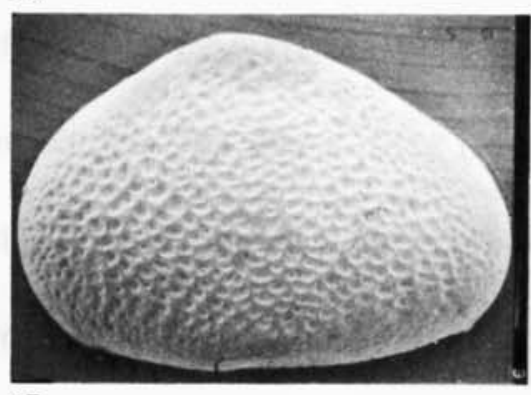

17

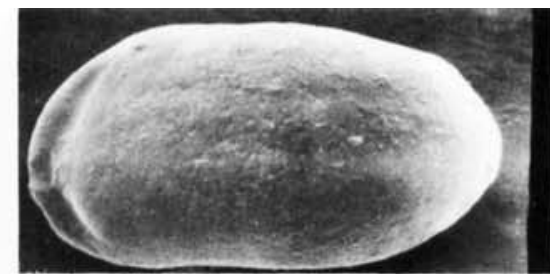

3

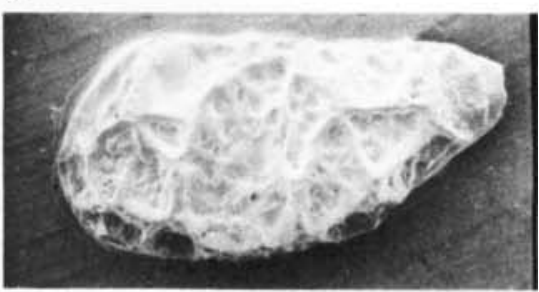

6

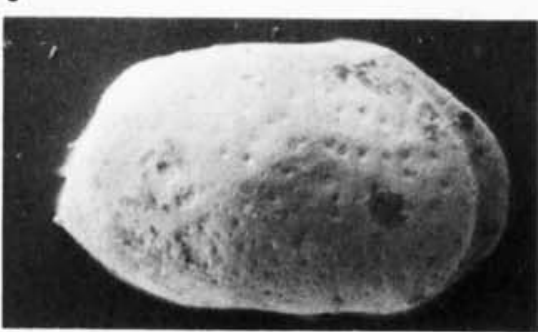

9

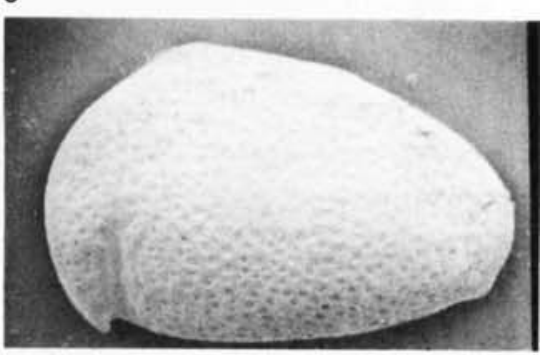

12

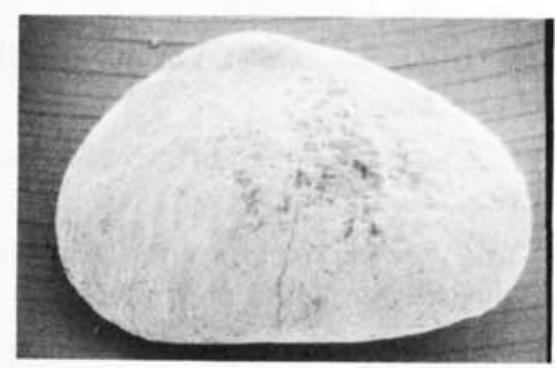

15

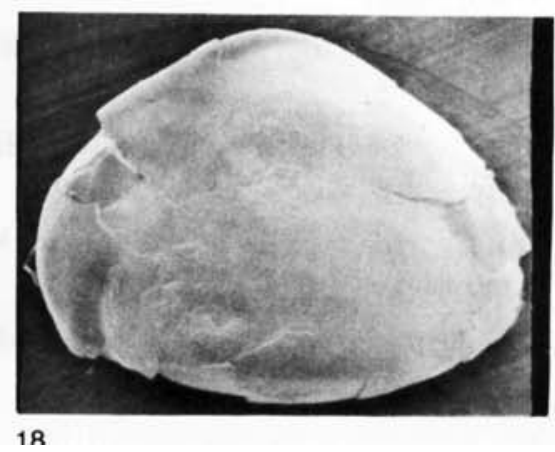




\section{Explanation of Plate 5}

Fig. 1. Procytheropteron brodiei (Jones), female; Mik(M) 3306; length 0.495 mm, height 0.31 mm; Ashdown No. 1 Borehole, Sussex.

p. 37

Fig. 2. Cypridea tuberculata tuberculata (J. de C. Sowerby), Mik(M) 2123 ; neotype; length $0.93 \mathrm{~mm}$, height $0.60 \mathrm{~mm}$; Cranbrook, Kent.

p. 32

Fig. 3. Macrodentina mediostricta (Sylvester-Bradley), male; Mik(M) 3292; length $1 \cdot 09 \mathrm{~mm}$, height $0 \cdot 59 \mathrm{~mm}$; Milkhurst Wood, Sussex.

p. 35

Fig. 4. Cypridea tuberculata adjuncta Jones, Mik(M) 3208; length $0.80 \mathrm{~mm}$, height $0.475 \mathrm{~mm}$; Henfield No. 1 Borehole, Sussex.

p. 32

Fig. 5. Cypridea tuberculata langtonensis Anderson, Mik(M) 3207; holotype; length $0.97 \mathrm{~mm}$, height $0.645 \mathrm{~mm}$; Warlingham Borehole, Surrey.

p. 32

Fig. 6. Cypridea setina bellatula Anderson, Mik(M) 2153; holotype; length $1.0 \mathrm{~mm}$, height 0.6 mm; Chilcomb Down Borehole, Hampshire.

p. 31

Fig. 7. Cypridea andersoni Wolburg, Mik(M) 3193; length $1.015 \mathrm{~mm}$, height $0.66 \mathrm{~mm}$; Chilcomb Down Borehole, Hampshire.

p. 25

Fig. 8. Cypridea propunctata Sylvester-Bradley, Mik(M) 3196; length $0.865 \mathrm{~mm}$, height $0.58 \mathrm{~mm}$; Chilcomb Down Borehole, Hampshire.

p. 30

Fig. 9. Cypridea setina setina (Anderson), Mik(M) 535; lectotype; length $0.95 \mathrm{~mm}$, height $0.6 \mathrm{~mm}$; Portsdown No. 1 Borehole, Hampshire.

Fig. 10. Cypridea amisia Wolburg, Mik(M) 3351; length $1.08 \mathrm{~mm}$, height $0.74 \mathrm{~mm}$; Chilcomb Down Borehole, Hampshire.

p. 25

Fig. 11. Cypridea darvelensis Anderson, Mik(M) 3167; holotype; length 1.075 mm, height $0.705 \mathrm{~mm}$; Warlingham Borehole, Surrey.

p. 27

Fig. 12. Cypridea setina acerata Anderson, Mik(M) 3204; holotype; length $1.015 \mathrm{~mm}$, height $0.63 \mathrm{~mm}$; Chilcomb Down Borehole, Hampshire.

p. 31

Fig. 13. Cypridea alta formosa Wolburg, Mik(M) 3189; length $0.97 \mathrm{~mm}$, height $0.76 \mathrm{~mm}$; Chilcomb Down Borehole, Hampshire.

p. 25

Fig. 14. Cypridea alta alta Wolburg, Mik(M) 3184; length $0.985 \mathrm{~mm}$, height $0.68 \mathrm{~mm}$; Portsdown No. 1 Borehole, Hampshire.

p. 25

Fig. 15. Cypridea obliqua Wolburg, Mik(M) 3212; length $1.03 \mathrm{~mm}$, height $0.66 \mathrm{~mm}$; Chilcomb Down Borehole, Hampshire.

p. 30

Fig. 16. Cypridea brevirostrata Martin, Mik(M) 3197; length $1.07 \mathrm{~mm}$, height $0.755 \mathrm{~mm}$; Chilcomb Down Borehole, Hampshire.

p. 26

Fig. 17. Cypridea vidrana Wolburg, Mik(M) 3180; length $1.115 \mathrm{~mm}$, height $0.775 \mathrm{~mm}$; Chilcomb Down Borehole, Hampshire.

p. 33

Fig. 18. Cypridea altissima Martin, Mik(M) 3301; length $1.07 \mathrm{~mm}$, height $0.83 \mathrm{~mm}$; Warlingham Borehole, Surrey. 


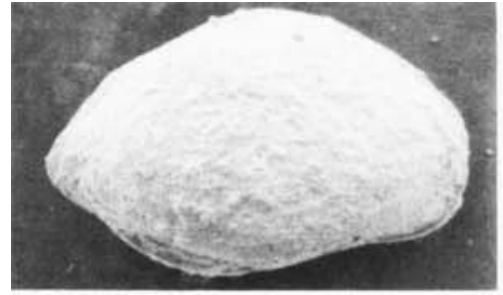

1

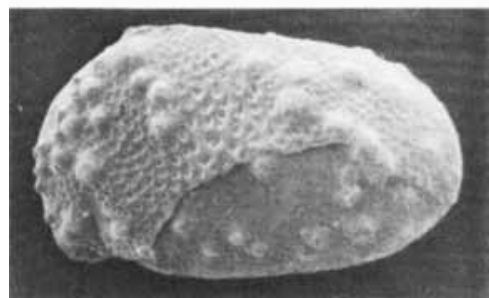

4

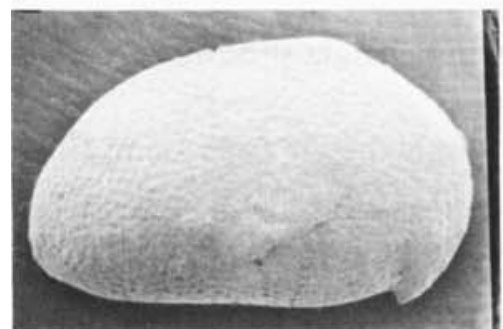

7

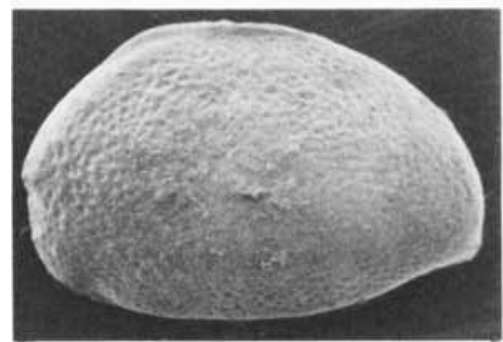

10

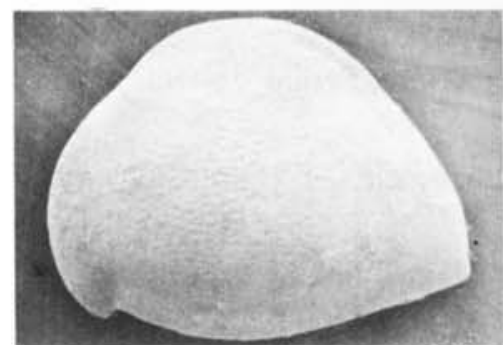

13

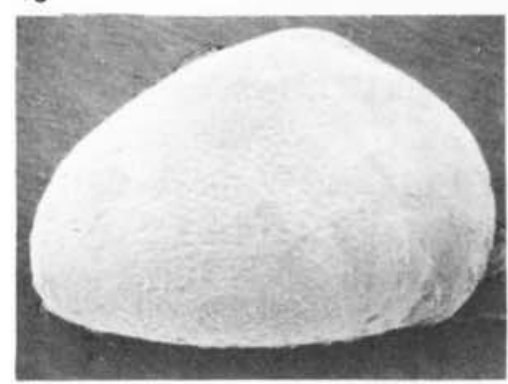

16

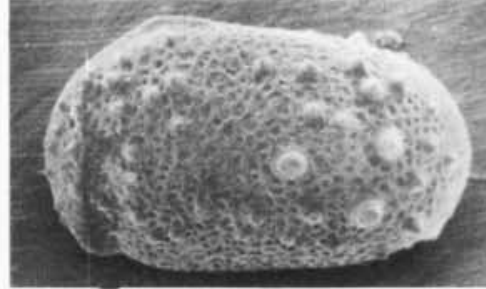

2

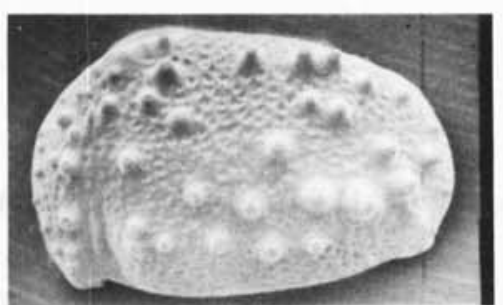

5

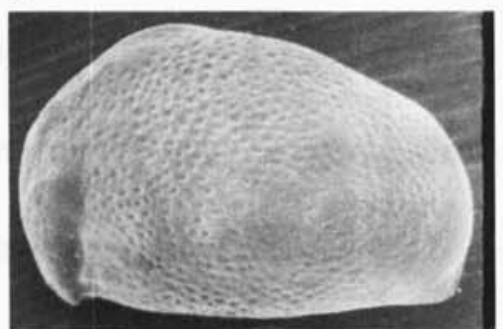

8

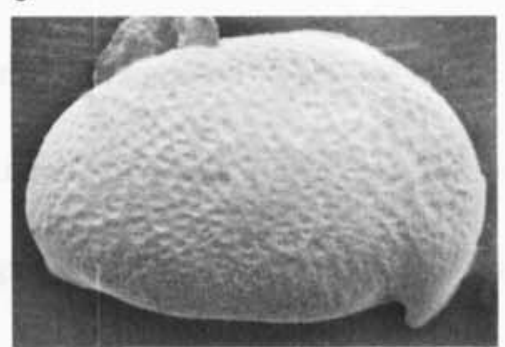

11

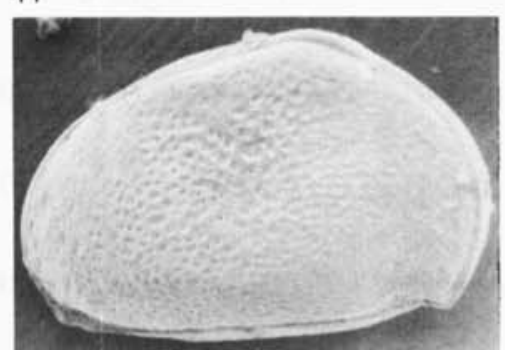

14

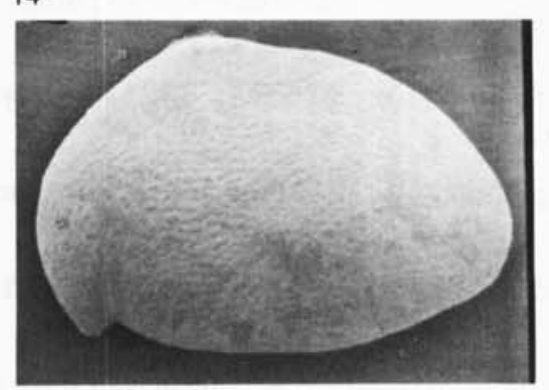

17

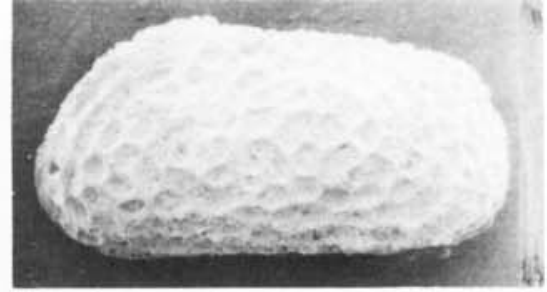

3

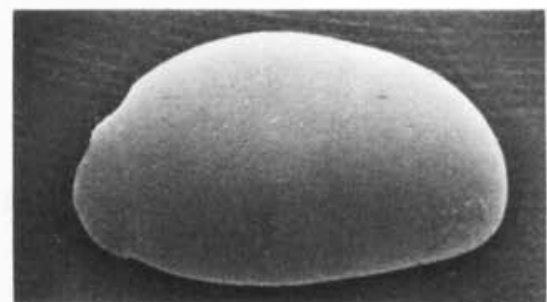

6

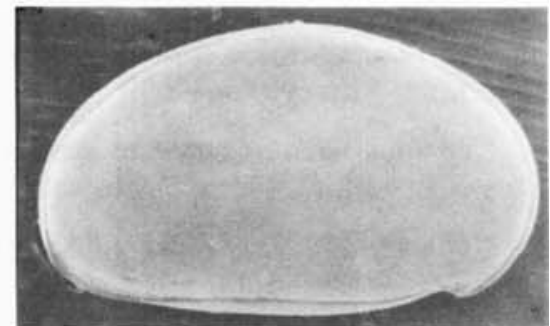

9

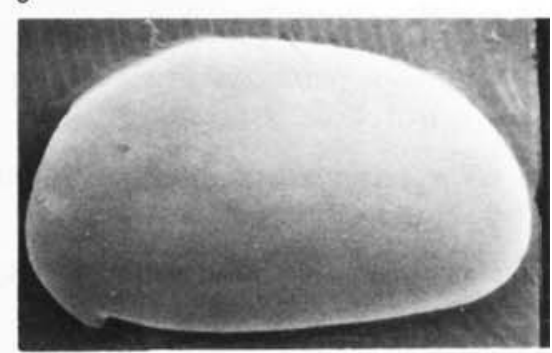

12

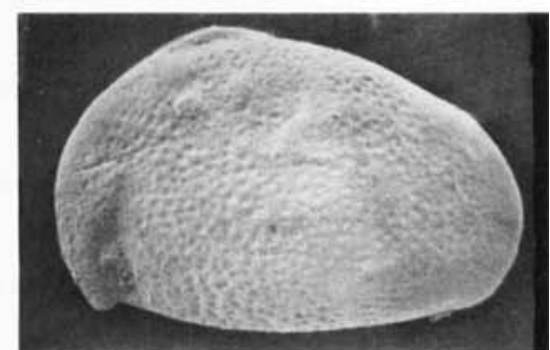

15

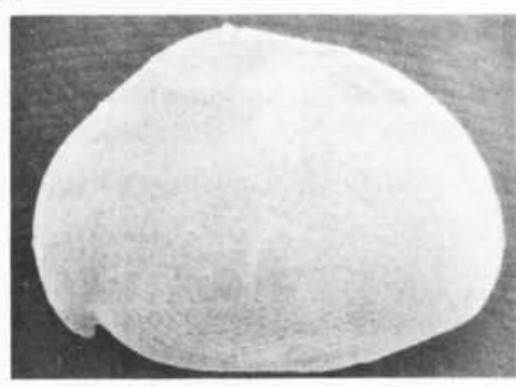

18 


\section{Explanation of Plate 6}

Fig. 1. Cypridea wicheri isabellae Anderson, Mik(M) 2166; holotype; length $0.95 \mathrm{~mm}$, height $0.61 \mathrm{~mm}$; Chilcomb Down Borehole, Hampshire.

$\mathrm{Fi}_{\text {g. }}$ 2. Cypridea wicheri torosa Anderson, $\mathrm{Mik}(\mathrm{M}) 2165$; length $0.95 \mathrm{~mm}$, height $0.61 \mathrm{~mm}$; Chilcomb Down 'Borehole, Hampshire.

Fig. 3. Cypridea aculeata eppili Anderson, Mik(M) 2137; holotype; length $0.95 \mathrm{~mm}$, height $0.59 \mathrm{~mm}$; Warlingham Borehole, Surrey.

Fig. 4. Cypridea wicheri veronae Anderson, Mik(M) 2162; holotype; length 0.96 mm, height $0.615 \mathrm{~mm}$; Chilcomb Down Borehole, Hampshire.

p. 33

Fig. 5. Cypridea aculeata eustacii Anderson, Mik(M) 2135; holotype; length $0 \cdot 88 \mathrm{~mm}$, height $0.57 \mathrm{~mm}$; Wadhurst Park No. 3 Borehole, Sussex.

Fig. 6. Cypridea setina erumna Anderson, Mik(M) 3313; holotype; length $0.985 \mathrm{~mm}$, height $0.63 \mathrm{~mm}$; Chilcomb Down Borehole, Hampshire.

Fig. 7. Cypridea setina deburghi Anderson, Mik(M) 2152; holotype; length $1.01 \mathrm{~mm}$, height $0.675 \mathrm{~mm}$; Chilcomb Down Borehole, Hampshire.

p. 31

Fig. 8. Cypridea aculeata antiqua Anderson, Mik(M) 2963; holotype; length 0.94 mm, height 0.59mm; Wadhurst Park No. 3 Borehole, Sussex.

Fig. 9. Cypridea aculeata aculeata Jones, Mik(M) 4492; length $0.93 \mathrm{~mm}$, height 0.56 mm; Philpotts Quarry, Sussex.

p. 25

Fig. 10. Cypridea wicheri wicheri Wolburg, Mik(M) 3166; length $0.97 \mathrm{~mm}$, height $0.63 \mathrm{~mm}$; Chilcomb Down Borehole, Hampshire.

p. 33

Fig. 11. Cypridea aculeata elgivae Anderson, Mik(M) 2931; holotype; length 0.92 mm, height 0.60 mm; Wadhurst Park No. 3 Borehole, Sussex.

Fig. 12. Cypridea setina dotica Anderson, Mik(M) 3311; holotype; length $1.02 \mathrm{~mm}$, height $0.69 \mathrm{~mm}$; Chilcomb Down Borehole, Hampshire.

Fig. 13. Cypridea wicheri croesi Anderson, Mik(M) 2160; holotype; length $0.97 \mathrm{~mm}$, height $0.66 \mathrm{~mm}$; Chilcomb Down Borehole, Hampshire.

Fig. 14. Cypridea setina rectidorsata Sylvester-Bradley, Mik(M) 3314 ; length $0.975 \mathrm{~mm}$, height $0.63 \mathrm{~mm}$; Chilcomb Down Borehole, Hampshire.

p. 31

Fig. 15. Cupridea bimammata prolifera Anderson, Mik(M) 3325; holotype; length $1.12 \mathrm{~mm}$, height $0.74 \mathrm{~mm}$; Mountfield No. 3 Borehole, Sussex.

p. 26

Fig. 16. Cypridea wicheri wicki Wolburg, Mik(M) 3302; length $0.93 \mathrm{~mm}$, height $0.615 \mathrm{~mm}$; Warlingham Borehole, Surrey.

p. 33

Fig. 17. Cypridea setina florida Anderson, Mik(M) 3200; topotype; length $1.095 \mathrm{~mm}$, height $0 \cdot 77 \mathrm{~mm}$; Chilcomb Down Borehole, Hampshire.

Fig. 18. Cypridea setina camelodes Anderson, Mik(M) 3202; holotype; length $0.985 \mathrm{~mm}$, height $0.71 \mathrm{~mm}$; Chilcomb Down Borehole, Hampshire. 


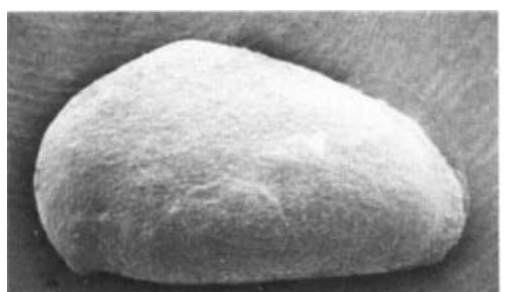

1

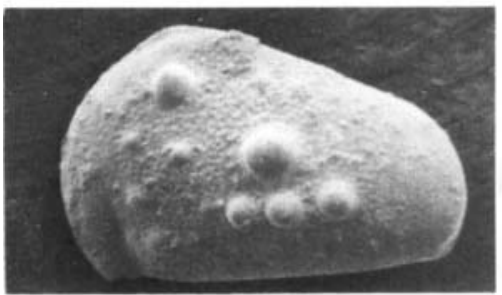

4

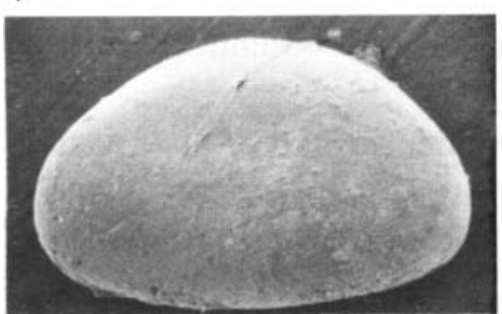

7

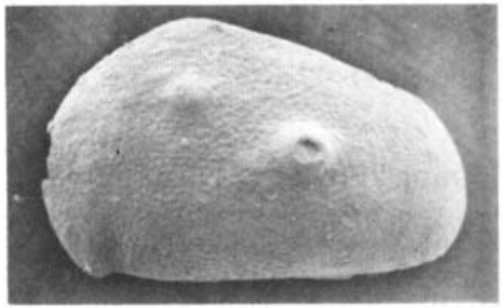

10

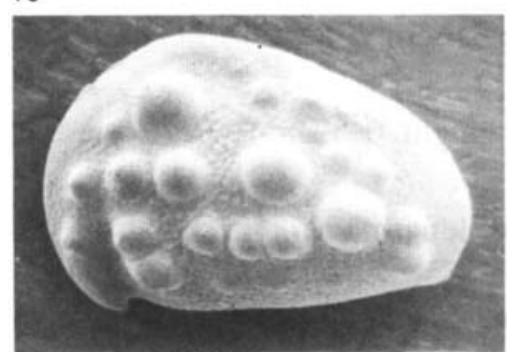

13

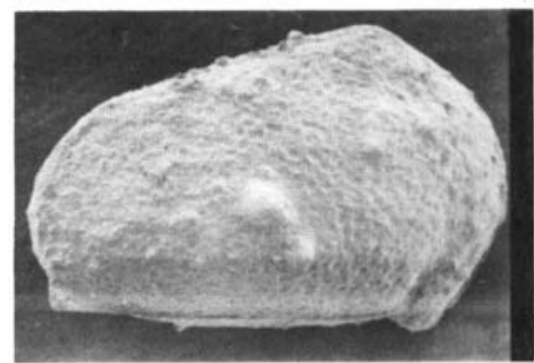

6

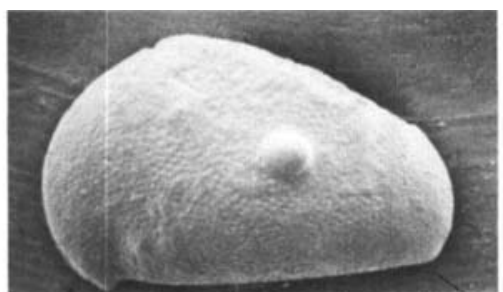

2

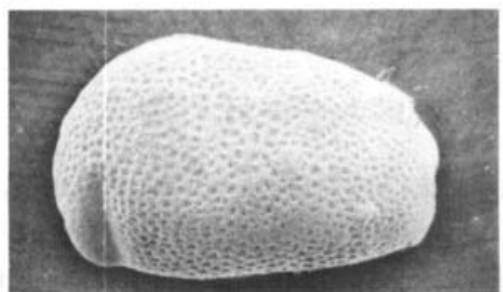

5

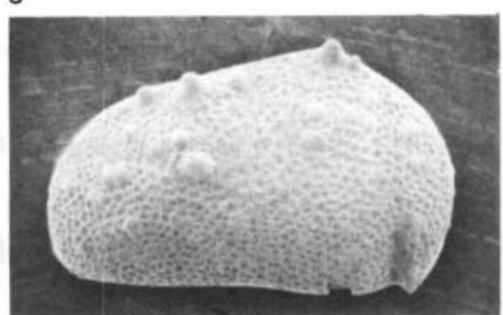

8

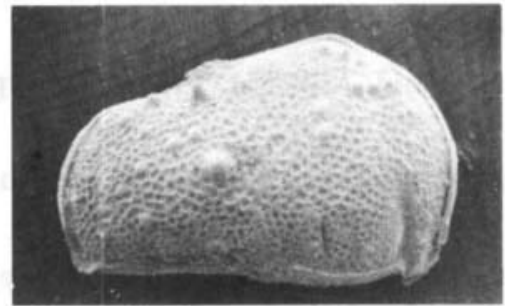

11

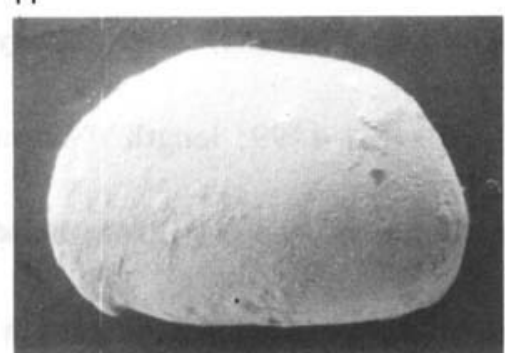

14

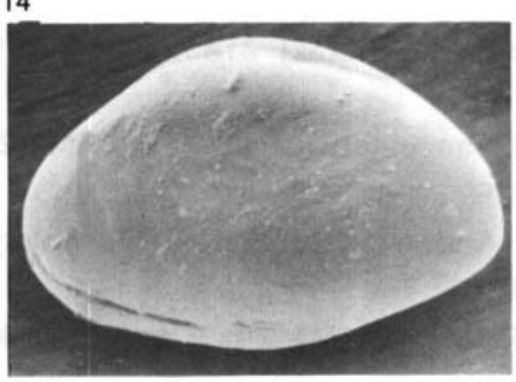

17

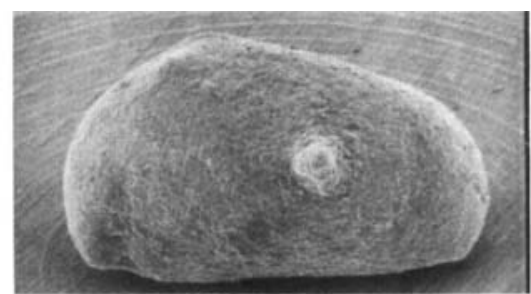

3

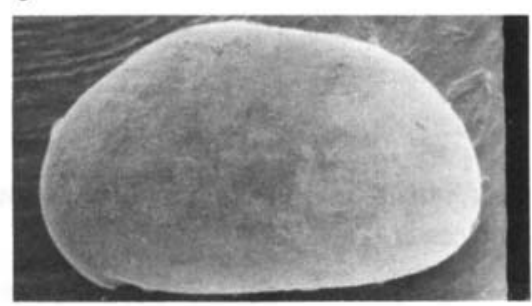

6

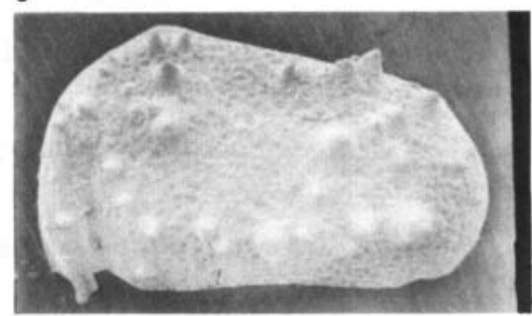

9

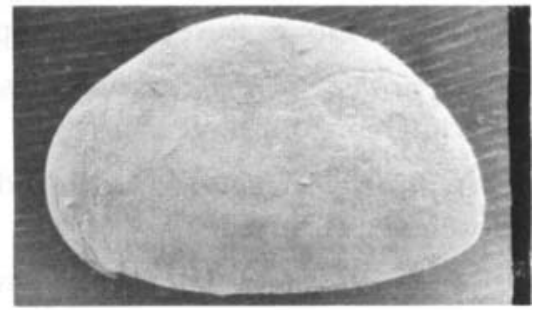

12

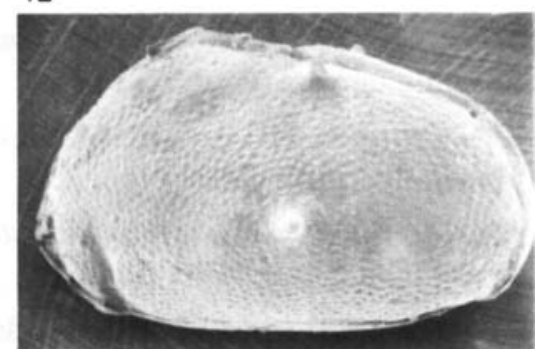

15

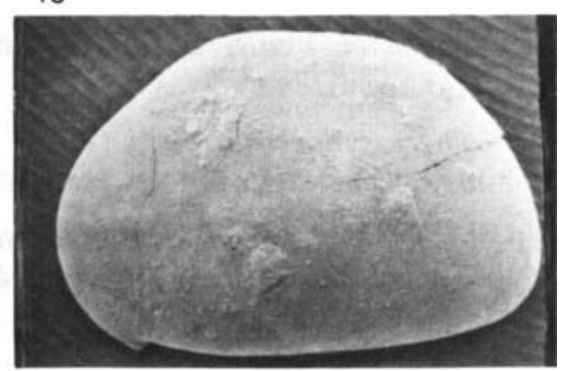

18 


\section{Explanation of Plate 7}

Fig. 1. Cypridea aculeata holmani Anderson, Mik(M) 2953; length $0.97 \mathrm{~mm}$, height $0.61 \mathrm{~mm}$; Warlingham Borehole, Surrey.

Fig. 2. Cypridea aculeata plautii Anderson, Mik(M) 2133; holotype; length $0.935 \mathrm{~mm}$, height $0.62 \mathrm{~mm}$; Wadhurst Park No. 3 Borehole, Sussex.

p. 25

Fig. 3. Cypridea laevigata laevigata (Dunker), Mik(M) 2146; length $1.13 \mathrm{~mm}$, height $0.66 \mathrm{~mm}$; Chilcomb Down Borehole, Hampshire.

Fig. 4. Cypridea aculeata regni Anderson, Mik(M) 2950; holotype; length $0.95 \mathrm{~mm}$, height $0.59 \mathrm{~mm}$; Warlingham Borehole, Surrey.

Fig. 5. Cypridea laevigata philpottsi Anderson, Mik(M) 2959; holotype; length $1.23 \mathrm{~mm}$, height $0.76 \mathrm{~mm}$; Philpotts Quarry, Sussex.

Fig. 6. Cypridea laevigata wadhurstensis Anderson, Mik(M) 2147; holotype; length $1.05 \mathrm{~mm}$, height $0.60 \mathrm{~mm}$; Chilcomb Down Borehole, Hampshire.

p. 29

Fig. 7. Cypridea aculeata subaculeata Anderson, Mik(M) 2951; holotype; length $0.97 \mathrm{~mm}$, height $0.62 \mathrm{~mm}$; Warlingham Borehole, Surrey.

p. 25

Fig. 8. Cypridea laevigata leonardi Anderson, Mik(M) 2149; holotype; length $1 \cdot 17 \mathrm{~mm}$, height $0 \cdot 71 \mathrm{~mm}$; Warlingham Borehole, Surrey.

Fig. 9. Cypridea laevigata fairlightensis Anderson, $\operatorname{Mik}(\mathrm{M}) 2151$; holotype; length $1 \cdot 16 \mathrm{~mm}$, height $0 \cdot 75 \mathrm{~mm}$; Warlingham Borehole, Surrey.

Fig. 10. Cypridea bispinosa suthrigensis Anderson, Mik(M) 2142 ; holotype; length $0.88 \mathrm{~mm}$, height $0.53 \mathrm{~mm}$; Warlingham Borehole, Surrey.

p. 26

Fig. 11. Cypridea menevensis (Anderson), Mik(M) 4499; length $0.90 \mathrm{~mm}$, height $0.52 \mathrm{~mm}$; Portsdown No. 1 Borehole, Sussex.

Fig. 12. Cypridea laevigata hawkhurstensis Anderson, Mik(M) 2148; holotype; length 1.07 mm, height $0 \cdot 64 \mathrm{~mm}$; Warlingham Borehole, Surrey.

Fig. 13. Cypridea bispinosa birini Anderson, Mik(M) 2143; holotype; length $0.94 \mathrm{~mm}$, height $0.60 \mathrm{~mm}$; Warlingham Borehole, Surrey.

p. 26

Fig. 14. Cypridea paulsgrovensis (Anderson), $\operatorname{Mik}(\mathrm{M}) 2155$; length $0.97 \mathrm{~mm}$, height $0.615 \mathrm{~mm}$; Warlingham Borehole, Surrey.

p. 30

Fig. 15. Theriosynoecum alleni (Pinto \& Sanguinetti), female; Mik(M) 2958; length 0.87 mm, height 0.55 mm; Chilcomb Down Borehole, Hampshire.

p. 37

Fig. 16. Cypridea laevigata subquadrata Anderson, Mik(M) 2150; holotype; length $1 \cdot 09 \mathrm{~mm}$, height $0 \cdot 83 \mathrm{~mm}$; Chilcomb Down Borehole, Hampshire.

p. 29

Fig. 17. Cypridea bispinosa bispinosa Jones, Mik(M) 2957; length $1.015 \mathrm{~mm}$, height $0.685 \mathrm{~mm}$; Warlingham Borehole, Surrey.

p. 26

Fig. 18. Cypridea ventrosa Jones, Mik(M) 3205; length $1.04 \mathrm{~mm}$, height $0.77 \mathrm{~mm}$; Swanage, Dorset. p. 33 

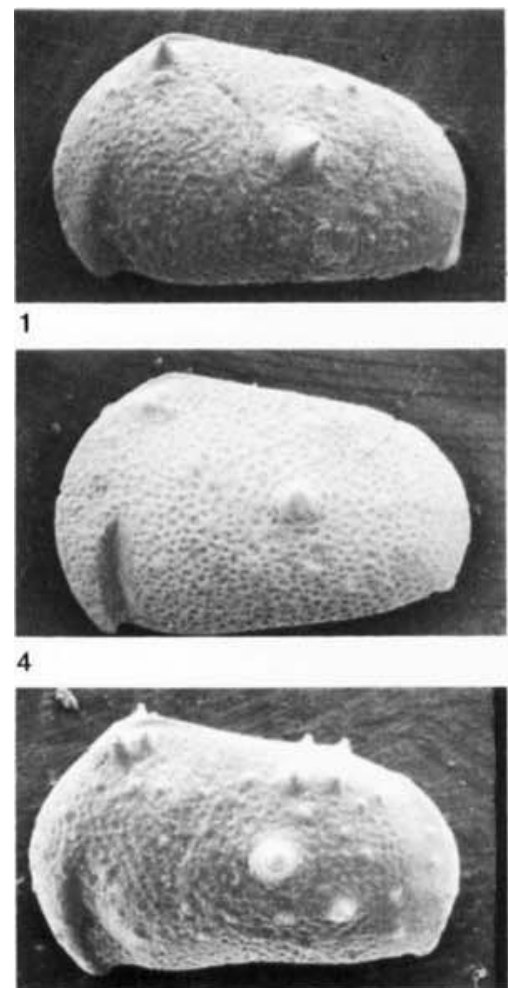

7

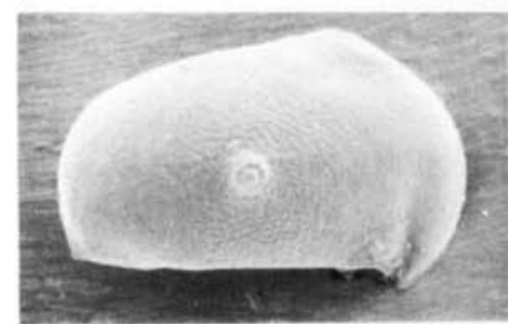

10

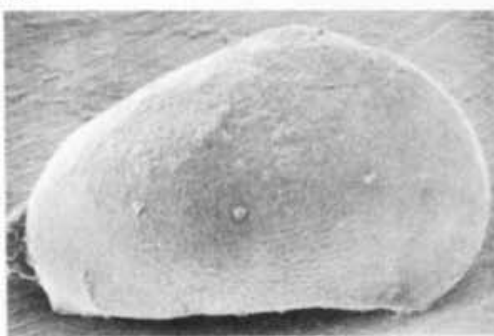

13

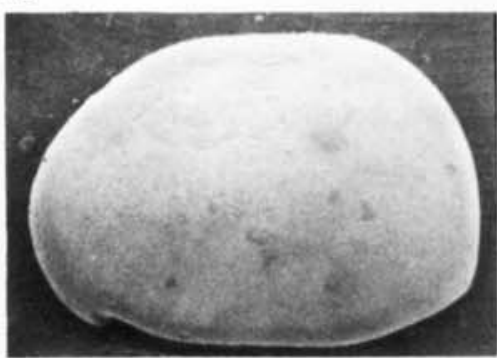

16

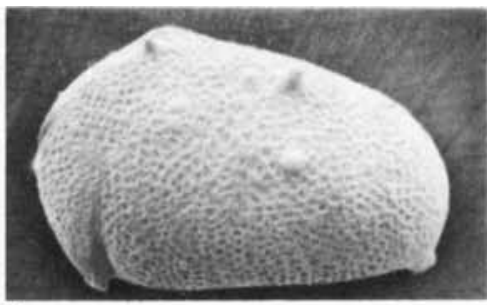

2

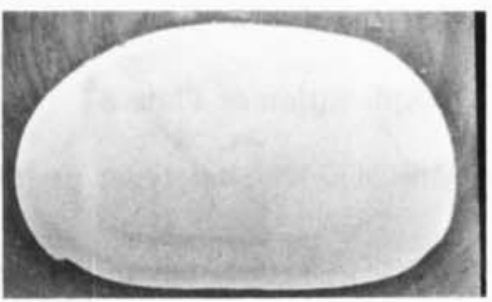

5

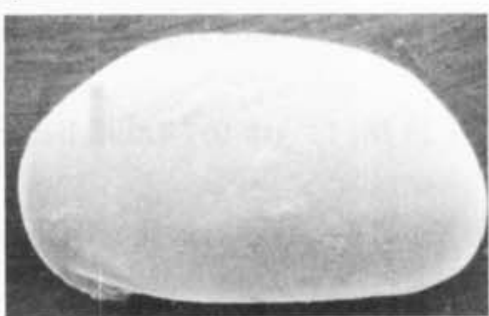

8

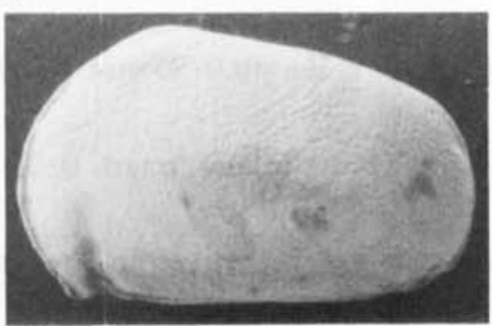

11

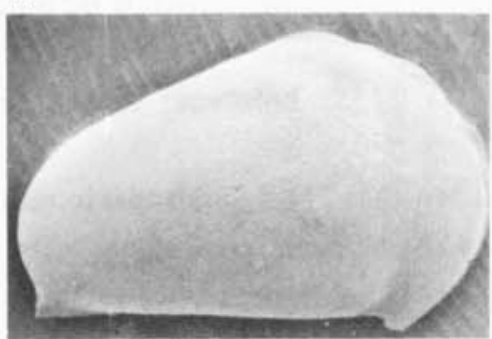

14

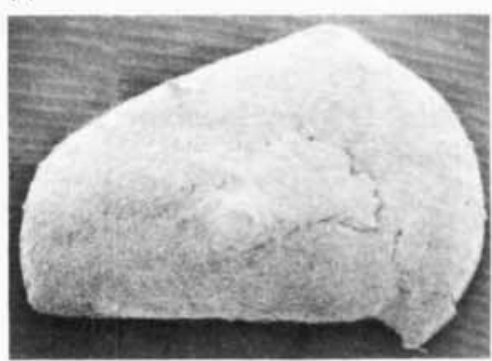

17

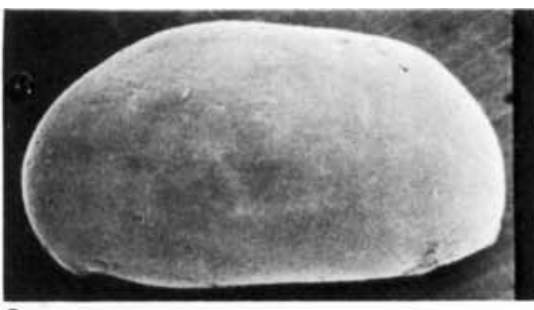

3

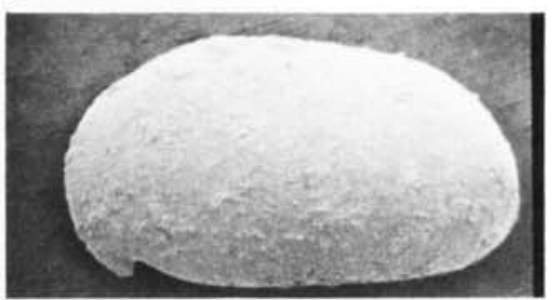

6

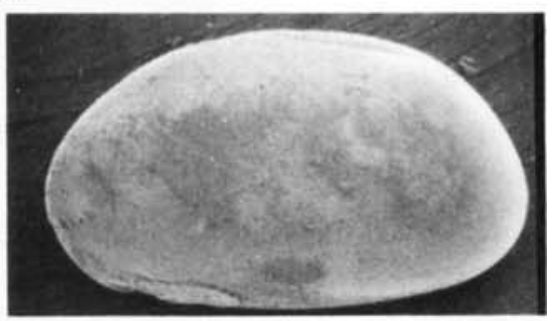

9

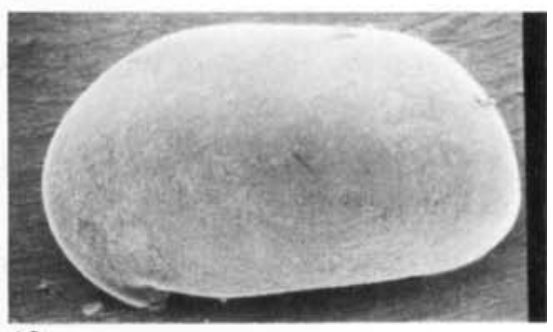

12

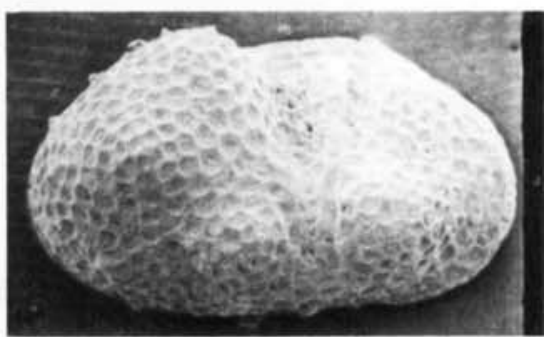

15

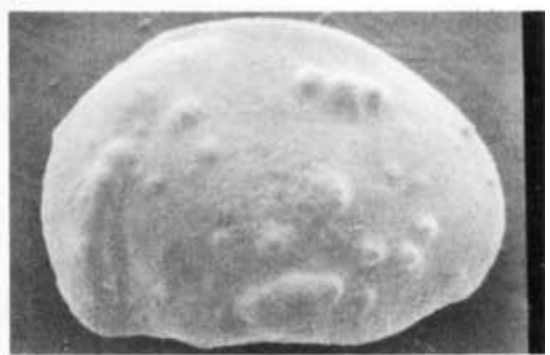

18 


\section{Explanation of Plate 8}

Fig. 1. Cypridea recta tillsdenensis Anderson, Mik(M) 2180; holotype; length $0.79 \mathrm{~mm}$, height $0.46 \mathrm{~mm}$; Warlingham Borehole, Surrey.

p. 31

Fig. 2. Cypridea blackbushensis Anderson, Mik(M) 2170; holotype; length $0.66 \mathrm{~mm}$, height $0.38 \mathrm{~mm}$; Blackbush Wood, Kent.

p. 26

Fig. 3. Cypridea frithwaldi Anderson, Mik(M) 2962; holotype; length $0.61 \mathrm{~mm}$, height $0.36 \mathrm{~mm}$; Warlingham Borehole, Surrey.

p. 28

Fig. 4. Cypridea recta recta Wolburg, Mik(M) 2178; length $0.79 \mathrm{~mm}$, height $0.48 \mathrm{~mm}$; Kingsclere No. 1 Borehole, Hampshire.

p. 31

Fig. 5. Cypridea recta edithae Anderson, Mik(M) 2181 ; holotype; length $0.86 \mathrm{~mm}$, height $0.51 \mathrm{~mm}$; Kingsclere No. 1 Borehole, Hampshire.

p. 31

Fig. 6. Mantelliana phillipsiana (Jones), female, Mik(M) 2960; length $1.96 \mathrm{~mm}$, height $1 \cdot 20 \mathrm{~mm}$; Black Horse Quarry, Binfield, Sussex.

p. 36

Fig. 7. Cypridea recta inflata Wolburg, Mik(M) 2179; length $0.77 \mathrm{~mm}$, height $0.50 \mathrm{~mm}$; Kingsclere No. 1 Borehole, Hampshire.

p. 31

Fig. 8. Cypridea melvillei Anderson. Mik(M) 2173; holotype; length $0.35 \mathrm{~mm}$, height $0.20 \mathrm{~mm}$; Kingsclere No. 1 Borehole, Hampshire.

p. 29

Fig. 9. Cytheridea (Haplocytheridea) delicatula Martin, Mik(M) 4495; length $0.56 \mathrm{~mm}$, height $0.345 \mathrm{~mm}$; Warlingham Borehole, Surrey.

p. 34

Fig. 10. Cypridea lasius Anderson, Mik(M) 2406; holotype; length 0.92 mm, height 0.58 mm; Wadhurst Park No. 1 Borehole, Sussex.

Fig. 11. Cypridea helenae Anderson. Mik(M) 2157: holotvpe; length $0.97 \mathrm{~mm}$, height 0.60 mm; Warlingham Borehole, Surrey.

p. 28

Fig. 12. Cypridea valdensis claudii Anderson, Mik(M) 2183; holotype; length $1 \cdot 31 \mathrm{~mm}$, height $0 \cdot 83 \mathrm{~mm}$; Warlingham Borehole, Surrey.

p. 33

Fig. 13. Cypridea pendae Anderson, Mik(M) 2141; holotype; length $1.0 \mathrm{~mm}$, height $0.66 \mathrm{~mm}$; Warlingham Borehole; Surrey.

p. 30

Fig. 14. Cypridea arenosa arenosa Anderson, Mik(M) 2138; holotype; length $0.94 \mathrm{~mm}$, height $0.62 \mathrm{~mm}$; Wadhurst Park N. 3 Borehole, Sussex.

p. 26

Fig. 15. Cypridea valdensis clareae Anderson, Mik(M) 2184; holotype; length $1.265 \mathrm{~mm}$, height $0.75 \mathrm{~mm}$; Warlingham Borehole, Surrey.

p. 33

Fig. 16. Cypridea morula Anderson, Mik(M) 2169; holotype; length $1.215 \mathrm{~mm}$, height $0.90 \mathrm{~mm}$; Chilcomb Down Borehole, Hampshire.

p. 30

Fig. 17. Cypridea verrucosa Jones, Mik(M) 2159 ; length $0.97 \mathrm{~mm}$, height $0.67 \mathrm{~mm}$; Kingsclere No. 1 Borehole, Hampshire.

p. 33

Fig. 18. Cypridea valdensis valdensis (J. de C. Sowerby), Mik(M) 1027; lectotype; length $1.28 \mathrm{~mm}$, height $0.90 \mathrm{~mm}$; near Hythe, Kent.

p. 32 


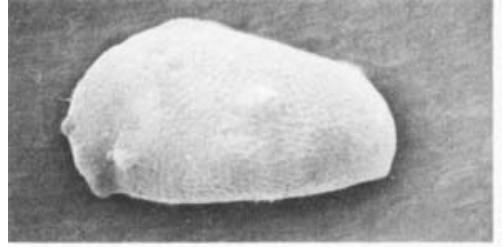

1

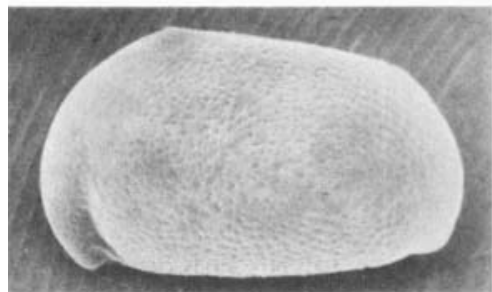

4

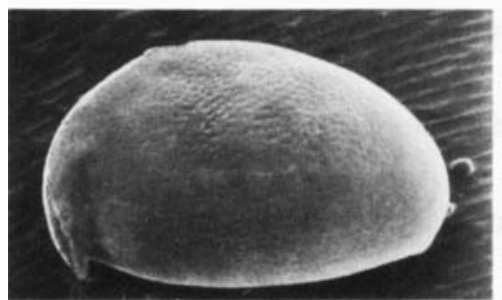

7

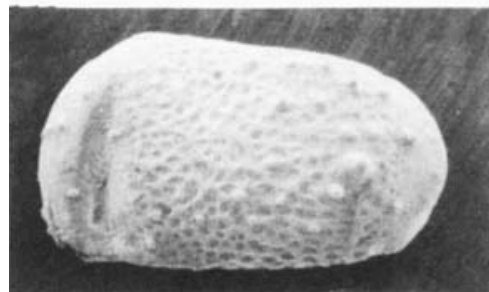

10

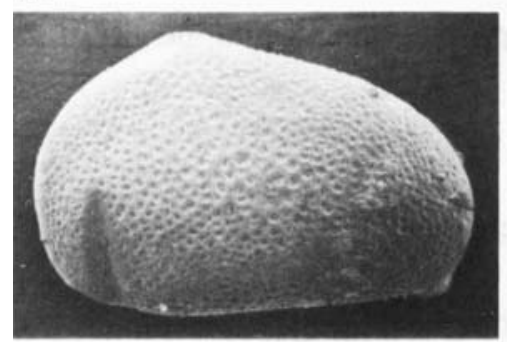

13

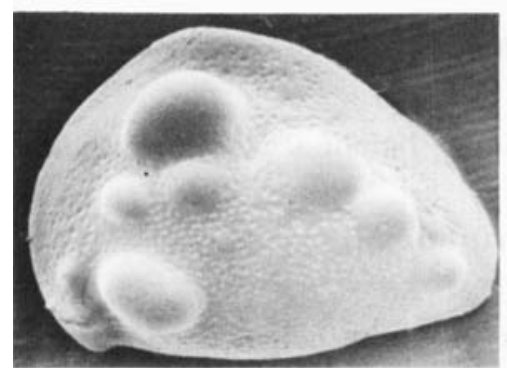

16

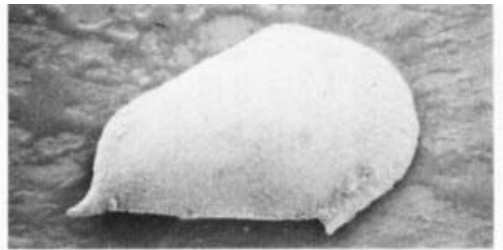

2

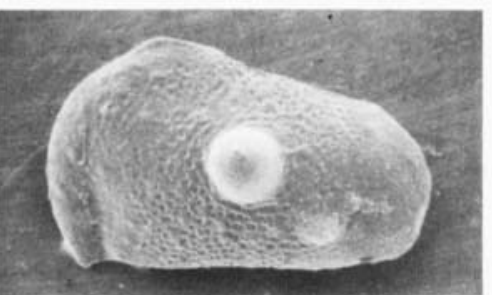

5

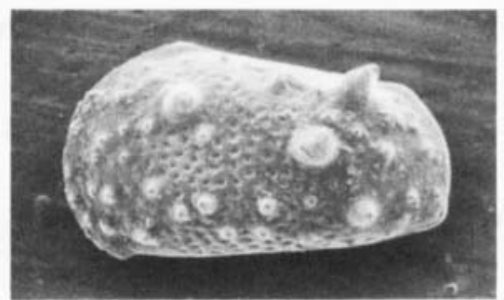

8

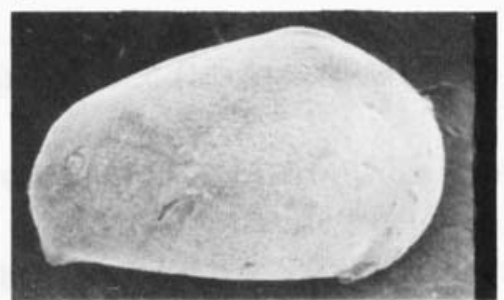

11

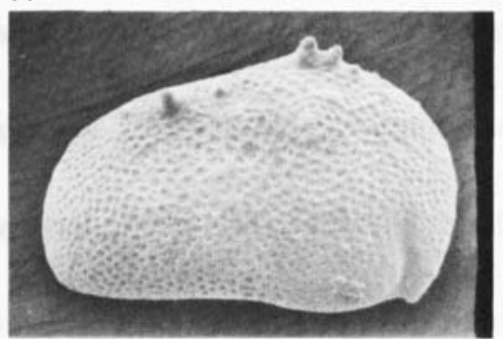

14

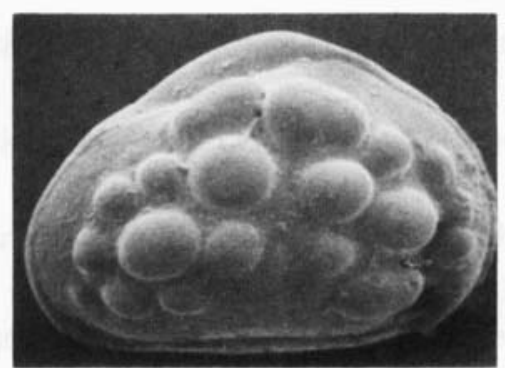

17

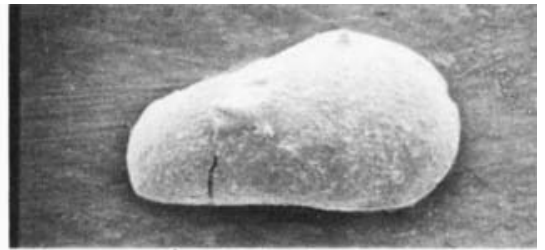

3

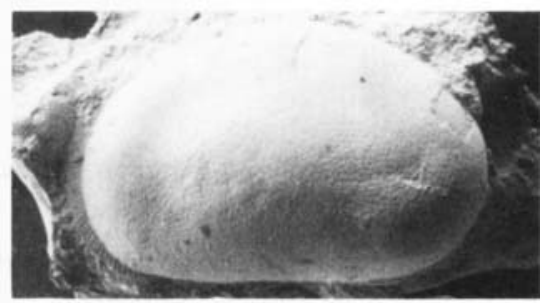

6

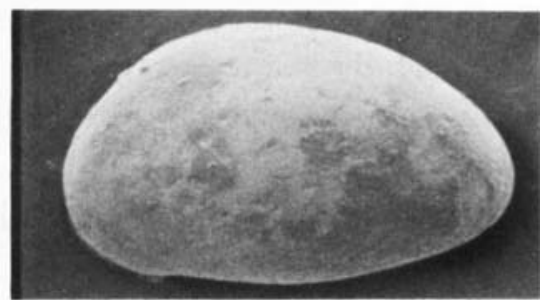

9

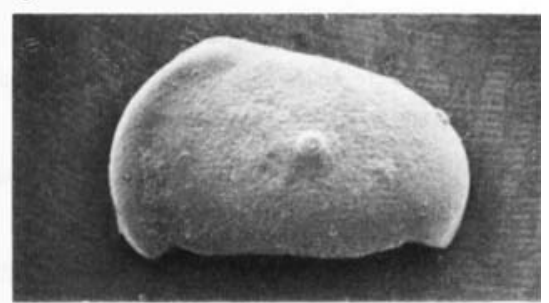

12

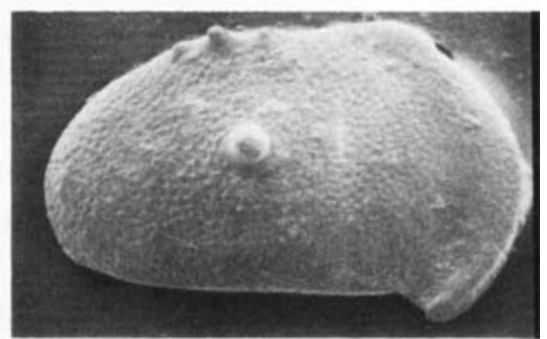

15

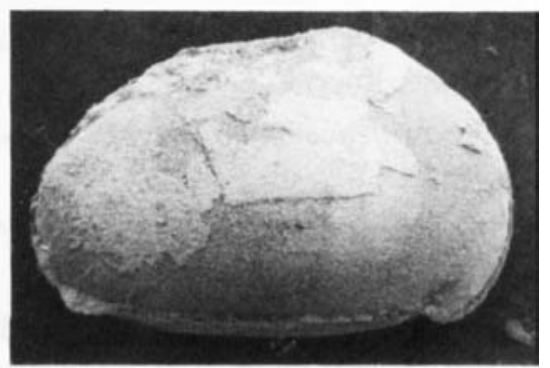

18 


\section{Explanation of Plate 9}

Fig. 1. Cypridea arenosa hengisti Anderson, Mik(M) 2139; holotype; length $0.89 \mathrm{~mm}$, height $0.60 \mathrm{~mm}$; Wadhurst Park No. 3 Borehole, Sussex.

p. 26

Fig. 2. Cypridea arenosa marshalli Anderson, Mik(M) 2140; holotype; length $0.98 \mathrm{~mm}$, height $0.62 \mathrm{~mm}$; Wadhurst Park No. 3 Borehole, Sussex.

p. 26

Fig. 3. Cypridea giffordi Anderson, Mik(M) 2171; holotype; length $0.4 \mathrm{~mm}$, height $0.25 \mathrm{~mm}$; Wadhurst Park No. 3 Borehole, Sussex.

p. 28

Fig. 4. Cypridea asseri Anderson, Mik (M) 2145; holotype; length 0.81 mm, height 0.47 mm; Warlingham Borehole, Surrey.

p. 26

Fig. 5. Mantelliana mantelli (Jones), Mik(M) 1004; lectotype; length $1.425 \mathrm{~mm}$, height $0.76 \mathrm{~mm}$; Atherfield, Isle of Wight.

p. 36

Fig. 6. Cypridea vericae Anderson, Mik(M) 2158; holotype; length 0.92 mm, height 0.55 mm; Wadhurst Park No. 3 Borehole, Sussex.

p. 33

Fig. 7. Cypridea dorsispinata dorsispinata (Anderson), Mik(M) 538; length $0.90 \mathrm{~mm}$, height $0.575 \mathrm{~mm}$; Henfield No. 1 Borehole, Sussex.

Fig. 8. Cypridea dorsispinata duplicata Anderson, $\operatorname{Mik}(\mathrm{M}) 2131$; holotype; length $0.87 \mathrm{~mm}$, height $0.51 \mathrm{~mm}$; Henfield No. 1 Borehole, Sussex.

Fig. 9. Cypridea dorsispinata gemella Anderson, Mik(M) 2129; holotype; length 0.93 mm, height $0.605 \mathrm{~mm}$; Henfield No. 1 Borehole, Sussex.

p. 27

Fig. 10. Cypridea dorsispinata quinquecornis Anderson, Mik(M) 2130; holotype; length $0.82 \mathrm{~mm}$, height $0.51 \mathrm{~mm}$; Henfield No. 1 Borehole, Sussex.

p. 27

Fig. 11. Cypridea dorsispinata tricornis Anderson, Mik(M) 2132; holotype; length $1.07 \mathrm{~mm}$, height $0.575 \mathrm{~mm}$; Henfield No. 1 Borehole, Sussex.

Fig. 12. Theriosynoecum fittoni (Mantell), female, Mik(M) 1905 ; lectotype; length $0.95 \mathrm{~mm}$, height $0.58 \mathrm{~mm}$; Punfield Cove, Dorset.

Fig. 13. Theriosynoecum fittoni (Mantell), male, Mik(M) 4498 ; length 1.0 mm, height $0.6 \mathrm{~mm}$; Ringwould Borehole, Kent.

p. 38

Fig. 14. Miocytheridea henfieldensis (Anderson), Mik(M) 3001; length $0.83 \mathrm{~mm}$, height $0.45 \mathrm{~mm}$; Henfield No. 1 Borehole, Sussex.

p. 36

Fig. 15. Cypridea clavata clavata (Anderson), Mik(M) 2379; length $0.805 \mathrm{~mm}$, height $0.48 \mathrm{~mm}$; Warlingham Borehole, Surrey.

Fig. 16. Cypridea dorsispinata roemeri (Anderson), Mik(M) 524 ; syntype; length $0 \cdot 86 \mathrm{~mm}$, height $0 \cdot 54 \mathrm{~mm}$; Henfield No. 1 Borehole, Sussex.

Fig. 17. Cypridea clavata bardana Anderson, Mik(M) 2383; holotype; length $1.04 \mathrm{~mm}$, height $0.655 \mathrm{~mm}$; Coldharbour Farm, Kent.

Fig. 18. Cypridea clavata beltana Anderson, Mik(M) 2382; holotype; length 1.0 mm, height 0.62 mm; Barham Mill, Kent. 

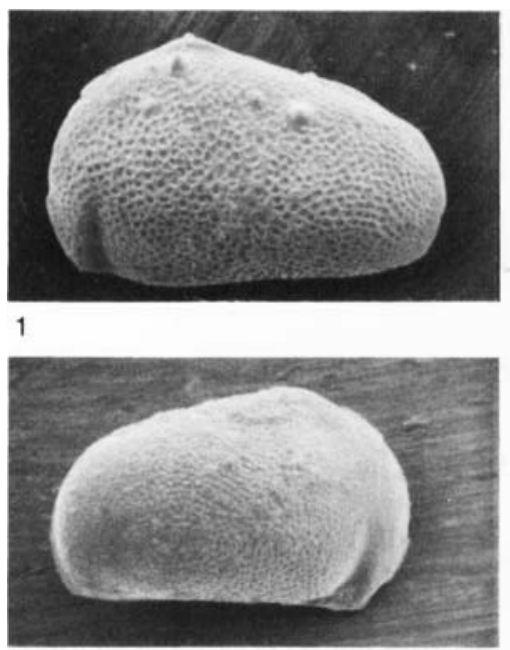

4

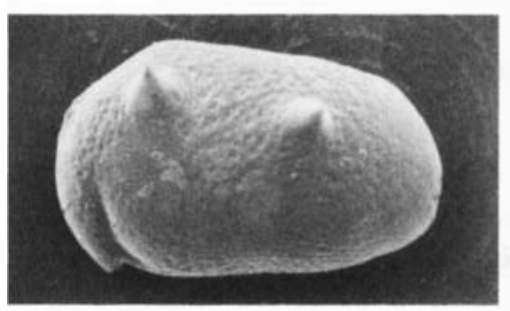

7

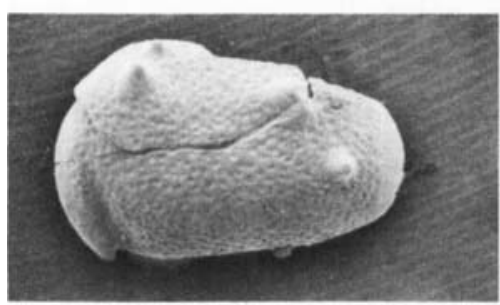

10

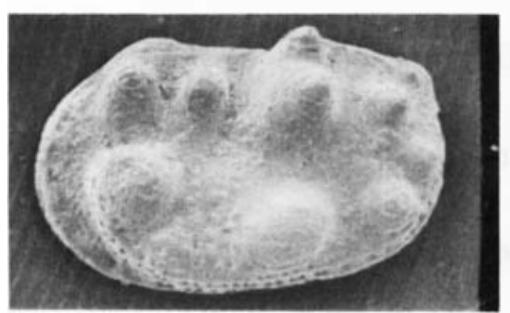

13

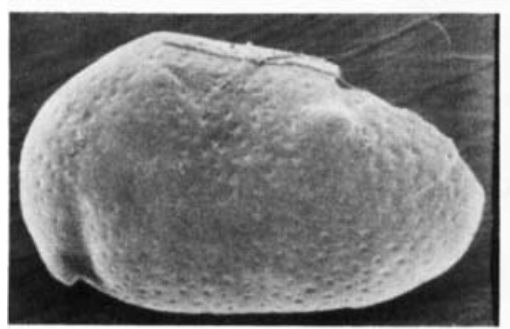

16

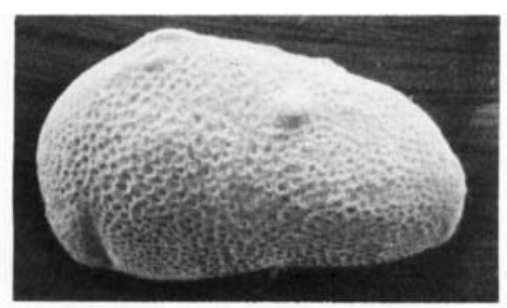

2

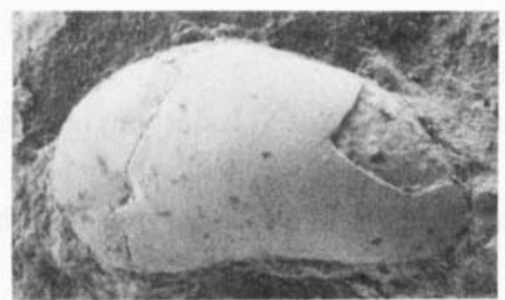

5

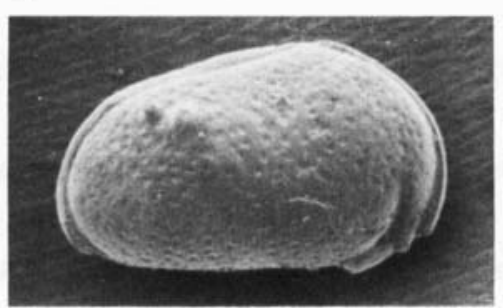

8

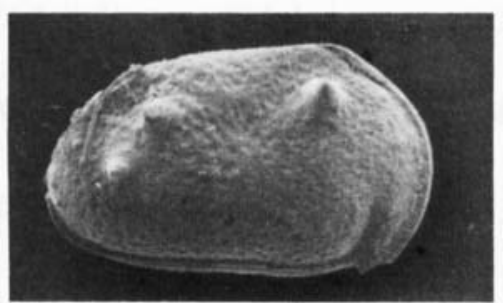

11

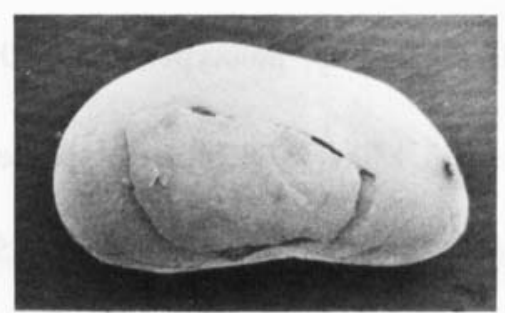

14

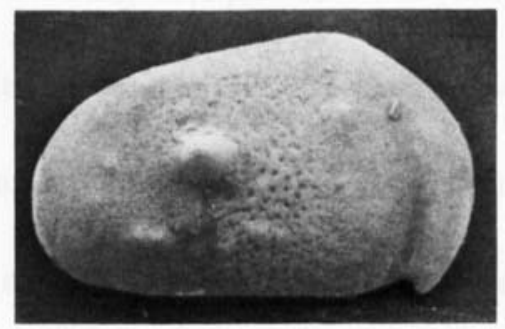

17

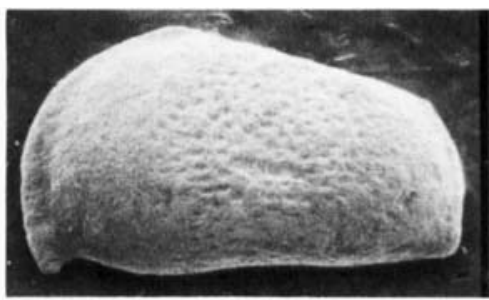

3

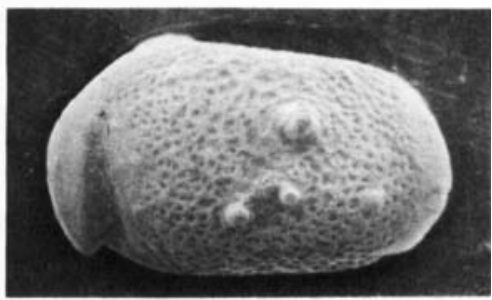

6

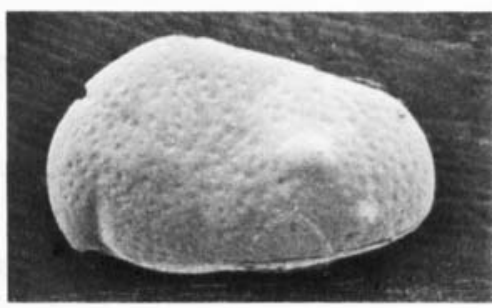

9

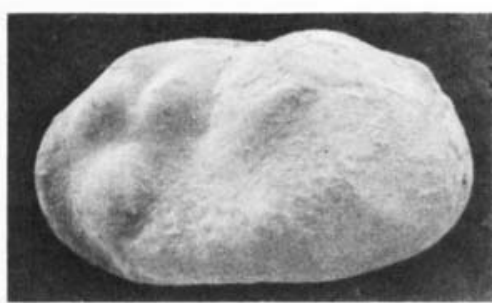

12

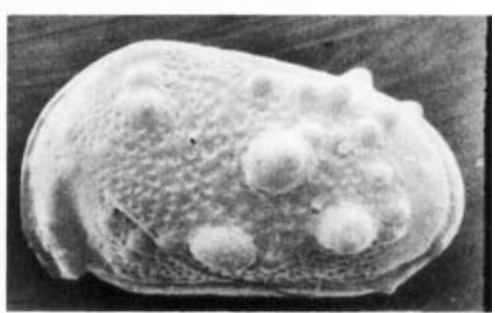

15

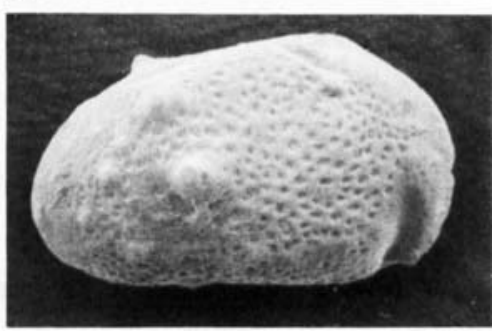

18 


\section{Explanantion of Plate 10}

Fig. 1. Cypridea clavata maleta Anderson, Mik(M) 2385; holotype; length $0.835 \mathrm{~mm}$, height $0.54 \mathrm{~mm}$; Warlingham Borehole, Surrey.

Fig. 2. Cypridea clavata mistrata Anderson, Mik(M) 2381; holotype; length $0.96 \mathrm{~mm}$, height $0.575 \mathrm{~mm}$; Warlingham Borehole, Surrey.

Fig. 3. Cypridea clavata talaria Anderson, Mik(M) 2380; holotype; length $0.90 \mathrm{~mm}$, height $0.52 \mathrm{~mm}$; Warlingham Borehole, Surrey.

Fig. 4. Cypridea pumila Anderson, Mik(M) 2120; holotype; length $0.99 \mathrm{~mm}$, height $0.61 \mathrm{~mm}$; Portsdown No. 1 Borehole, Hampshire.

Fig. 5. Cypridea brendae sp. nov., Mik(M) 4485; holotype; length $0.85 \mathrm{~mm}$, height $0.51 \mathrm{~mm}$; Cuckfield No. 2 Borehole, Sussex.

Fig. 6. Cypridea hispida sp. nov., Mik(M) 4486; holotype; length $0.72 \mathrm{~mm}$, height $0.43 \mathrm{~mm}$; Hailsham Borehole, Sussex.

p. 28

Fig. 7. Cypridea pseudomarina Anderson, $\operatorname{Mik}(\mathrm{M}) 2119$; holotype; length $0.925 \mathrm{~mm}$, height $0.575 \mathrm{~mm}$; Atherfield, Isle of Wight.

p. 30

Fig. 8. Cypridea fasciata Anderson, Mik(M) 2116; holotype; length $0.825 \mathrm{~mm}$, height $0.52 \mathrm{~mm}$; Atherfield, Isle of Wight.

p. 28

Fig. 9. Cypridea rotundata Anderson, Mik(M) 2121 ; holotype; length $0.79 \mathrm{~mm}$, height $0.51 \mathrm{~mm}$; Brookhurst Pottery Brick Pit, Surrey.

p. 31

Fig. 10. Cypridea bogdenensis Anderson, Mik(M) 2113; holotype; length 0.91 mm, height 0.55 mm; Bogden, Kent.

p. 26

Fig. 11. Cypridea tenuis Anderson, Mik(M) 2122; holotype; length 0.905 mm, height $0.49 \mathrm{~mm}$; Hythe, Kent.

p. 32

Fig. 12. Cypridea hamata Anderson, Mik(M) 2117; holotype; length $0.705 \mathrm{~mm}$, height $0.48 \mathrm{~mm}$; Warlingham Borehole, Surrey.

p. 28

Fig. 13. Cypridea spinigera (J. de C. Sowerby), Mik(M) 2175; lectotype; length $0.93 \mathrm{~mm}$, height $0.56 \mathrm{~mm}$; Sandown Bay, Isle of Wight.

p. 32

$\dagger$ Fig. 14. Cypridea insulae Anderson, Mik(M) 2400; holotype; length $0.495 \mathrm{~mm}$, height $0.29 \mathrm{~mm}$; Shepherd's Chine, Isle of Wight.

p. 29

Fig. 15. Cypridea caudata Anderson, Mik(M) 2114; holotype; length $0.71 \mathrm{~mm}$, height $0.485 \mathrm{~mm}$; Atherfield, Isle of Wight.

p. 26

Fig. 16. Cypridea clavata gordana Anderson, Mik(M) 2384; holotype; length $1.04 \mathrm{~mm}$, height $0.65 \mathrm{~mm}$; Coldharbour Farm, Kent.

p. 27

Fig. 17. Cypridea marina Anderson, Mik(M) 2118; holotype; length $0.88 \mathrm{~mm}$, height $0.57 \mathrm{~mm}$; Tongham Borehole, Sussex.

p. 29

Fig. 18. Cypridea comptonensis Anderson, Mik(M) 2395; holotype; length $1 \cdot 159 \mathrm{~mm}$, height $0.725 \mathrm{~mm}$; Shepherd's Chine, Isle of Wight.

$\dagger$ In explanation of Plate XVI, figs. 10-14, Anderson, 1967, p. 262 quotes the holotype of $C$. insulae as Mik (M) 2499; the number is correctly given in the description (p. 246) as Mik(M) 2400. 


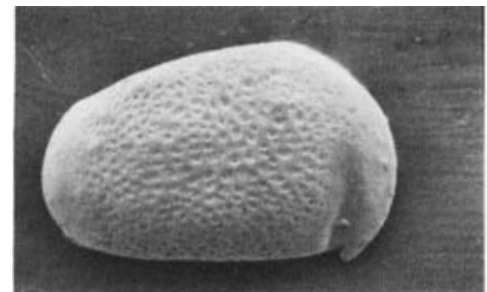

1

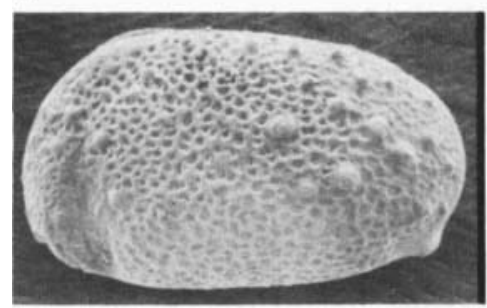

4

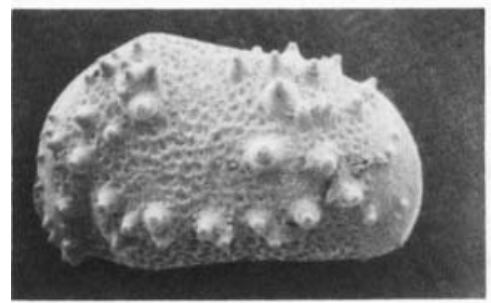

7

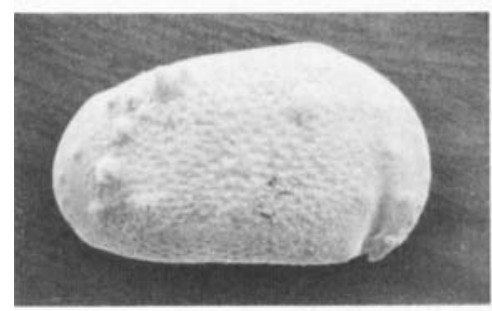

10

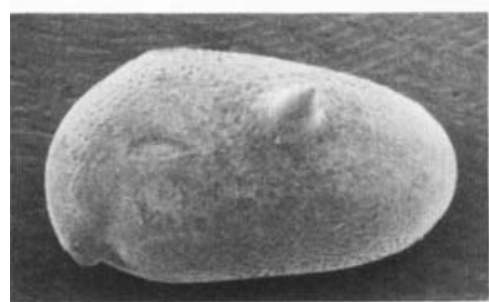

13

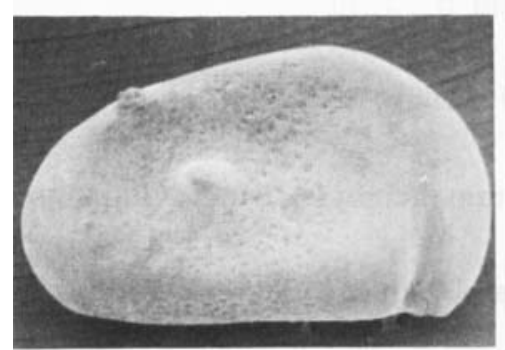

16

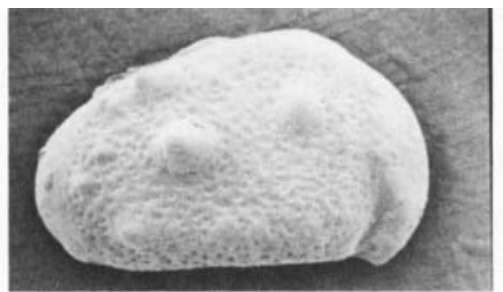

2

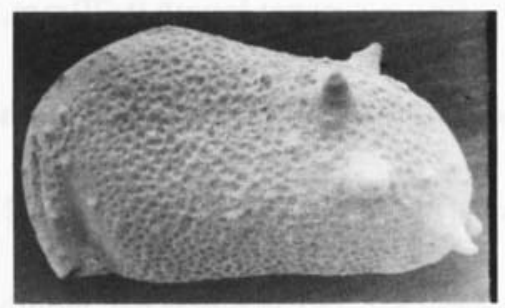

5

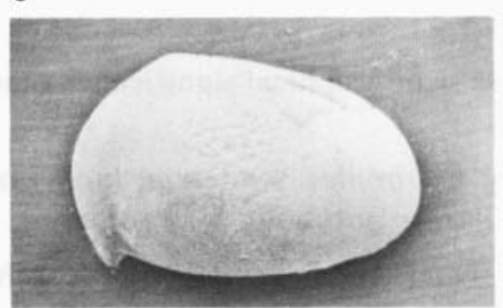

8

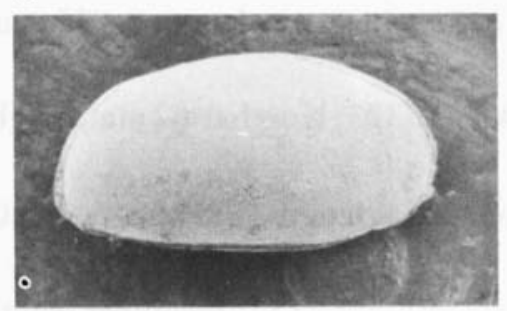

11

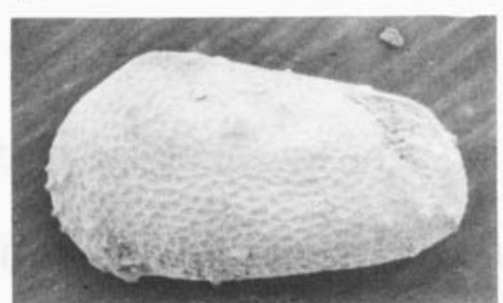

14

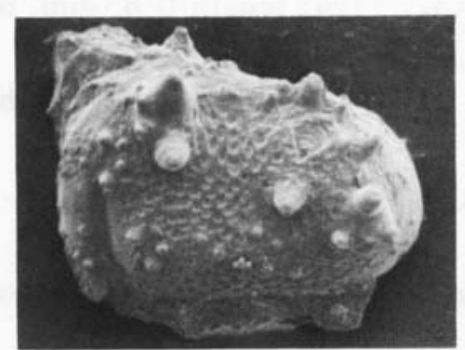

17

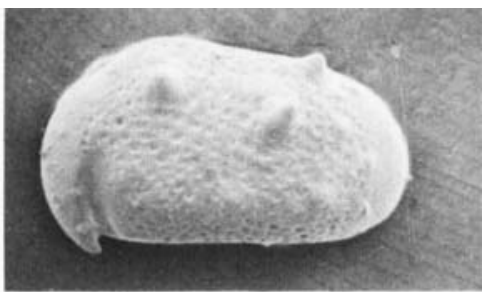

3

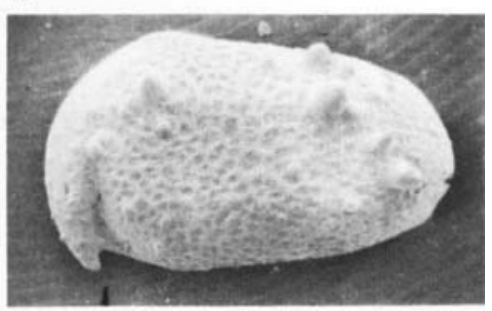

6

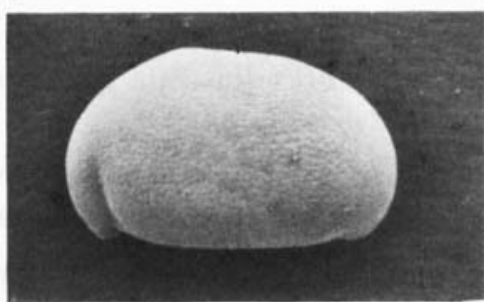

9

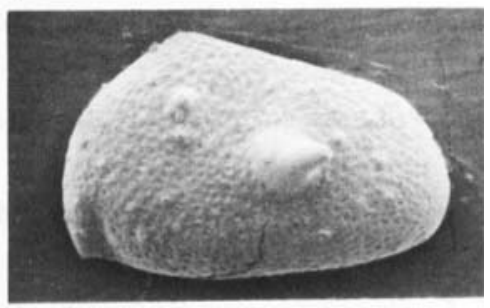

12

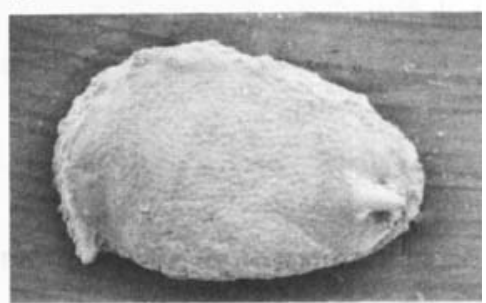

15

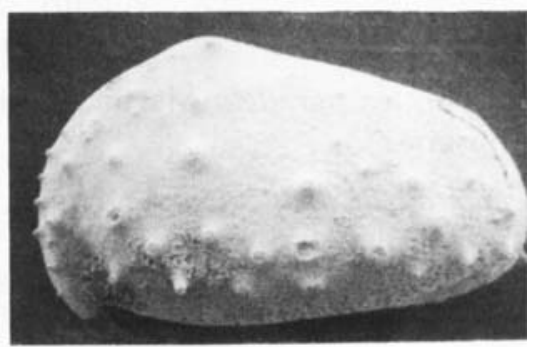

18 


\section{Explanation of Plate 11}

Fig. 1. Cypridea vectae Anderson, Mik(M) 2399; holotype; length $0.79 \mathrm{~mm}$, height $0.48 \mathrm{~mm}$; Shepherd's Chine, Isle of Wight.

Fig. 2. Cypridea warlinghamensis Anderson, Mik(M) 2401 ; holotype; length $0 \cdot 765 \mathrm{~mm}$, height $0 \cdot 46 \mathrm{~mm}$; Shepherd's Chine, Isle of Wight.

Fig. 3. Sternbergella cornigera (Jones), Mik(M) 1013; lectotype; length $0.92 \mathrm{~mm}$, height $0.51 \mathrm{~mm}$; Atherfield, Isle of Wight.

p. 37

Fig. 4. Cypridea cuckmerensis Anderson, Mik(M) 2115; holotype; length 0.81 mm, height $0.475 \mathrm{~mm}$; Berwick, Sussex.

The following figures illustrate species of less stratigraphical significance than those preceding either because of their rarity or of their long range.

Fig. 5. Cypridea simplissima nom. nov. for C. simplex Anderson (non Galeeva), Mik(M) 3209; holotype; length $0.72 \mathrm{~mm}$, height $0.46 \mathrm{~mm}$; Chilcomb Down Borehole, Hampshire.

p. 31

Fig. 6. Eoparacypris abbreviata Anderson, Mik(M) 3278; holotype; length 0.665 mm, height 0.39 mm; Chilcomb Down Borehole, Hampshire.

Fig. 7. Darwinula jonesi Anderson, Mik(M) 3326; holotype; length 0.935 mm, height $0.385 \mathrm{~mm}$; Wateringbury, Kent. p. 34

Fig. 8. Darwinula leguminella (Forbes), Mik(M) 3323; length $0.62 \mathrm{~mm}$, height $0.26 \mathrm{~mm}$; Mountfield No. 3 Borehole, Sussex.

Fig. 9. Darwinula oblonga (Roemer), Mik(M) 3324; length $1.15 \mathrm{~mm}$, height $0.525 \mathrm{~mm}$; Warninglid Borehole, Sussex.

Fig. 10. Cypridea setina pelota sub. sp. nov., Mik(M) 2154 ; holotype; length $0.89 \mathrm{~mm}$, height $0.61 \mathrm{~mm}$; Kingsclere No. 1 Borehole, Hampshire.

Fig. 11. Cypridea tuberculata indigens Anderson, Mik(M) 4494; length $0.88 \mathrm{~mm}$, height $0.5 \mathrm{~mm}$; Warlingham Borehole, Surrey.

p. 32

Fig. 12. Cypridea varians Anderson, Mik(M) 3210; holotype; length $0.77 \mathrm{~mm}$, height $0.54 \mathrm{~mm}$; Chilcomb Down Borehole, Hampshire.

p. 33

Fig. 13. Cypridea wolburgi Anderson, Mik(M) 3206; holotype; length $1.0 \mathrm{~mm}$, height $0.705 \mathrm{~mm}$; Warlingham Borehole, Surrey.

p. 33

Fig. 14. Cypridea cf. martini Wolburg, Mik(M) 3194; length $0.83 \mathrm{~mm}$, height $0.53 \mathrm{~mm}$; Warlingham Borehole, Surrey.

p. 29

Fig. 15. Cypridea parallela Martin, Mik(M) 2174; length 1.01 mm, height $0.63 \mathrm{~mm}$; Chilcomb Down Borehole, Hampshire.

p. 30

Fig. 16. Damonella denticulata Anderson, Mik(M) 2485 ; holotype; length $0.57 \mathrm{~mm}$, height $0.34 \mathrm{~mm}$; Gillmans Brick Pit, Billingshurst, Sussex.

p. 34

Fig. 17. Damonella punctatula Anderson, Mik(M) 2486; holotype; length $0.45 \mathrm{~mm}$, height $0.31 \mathrm{~mm}$; Wadhurst No. 3 Borehole, Sussex.

p. 34

Fig. 18. Cypridea tuberculata dorsiclavata sub. sp. nov., Mik(M) 4488; holotype; length $0.915 \mathrm{~mm}$, height $0.655 \mathrm{~mm}$; Warninglid Borehole, Sussex. 


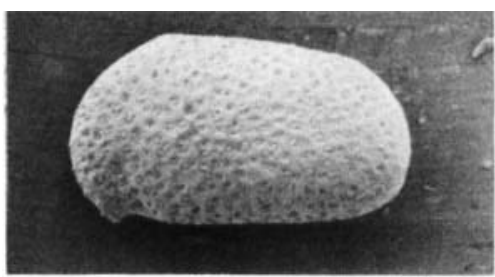

1

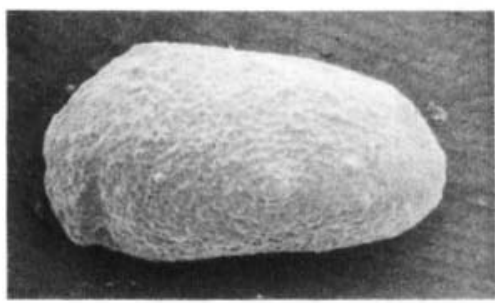

4

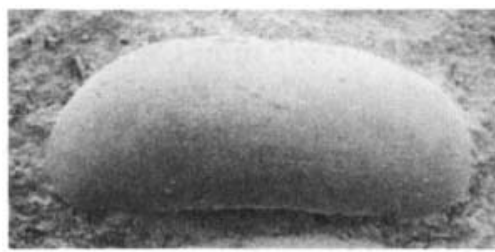

7

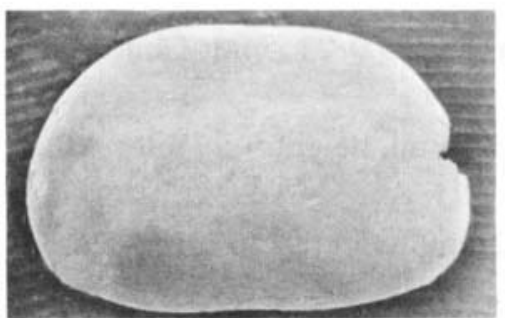

10

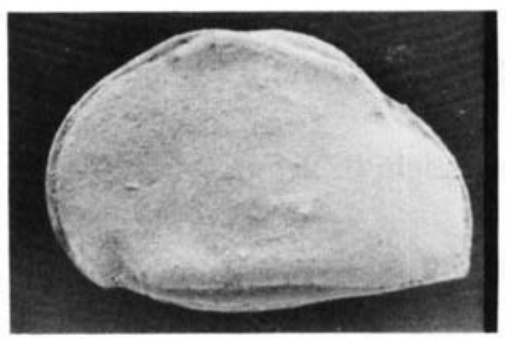

13

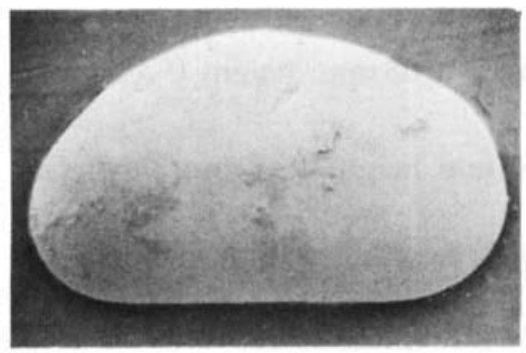

16

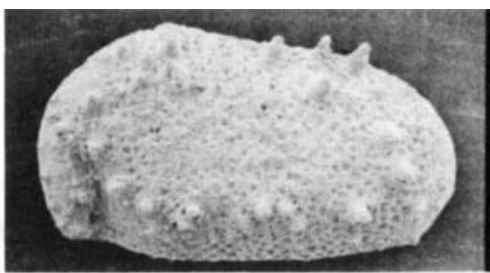

2

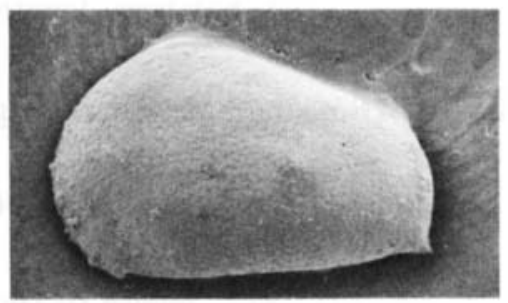

5

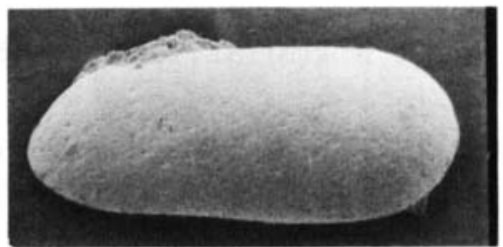

8

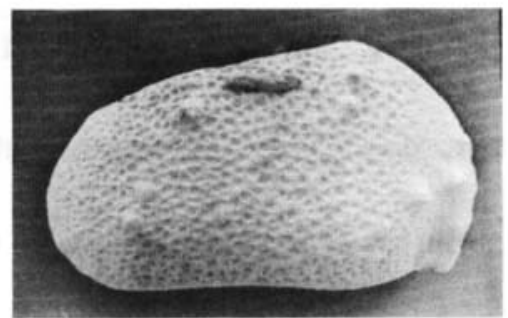

11

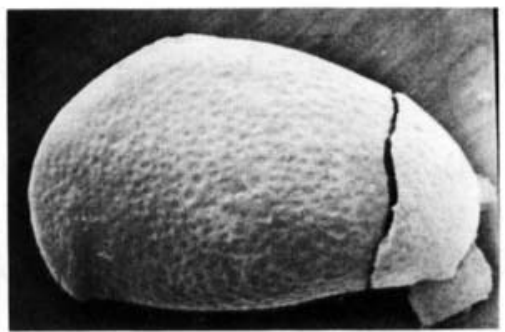

14

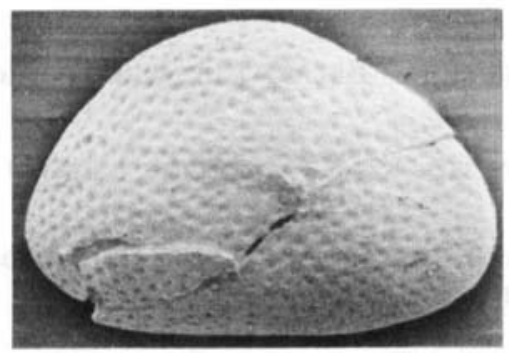

17

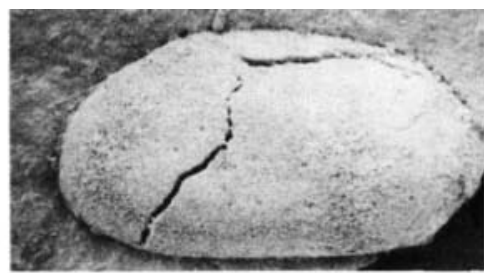

3

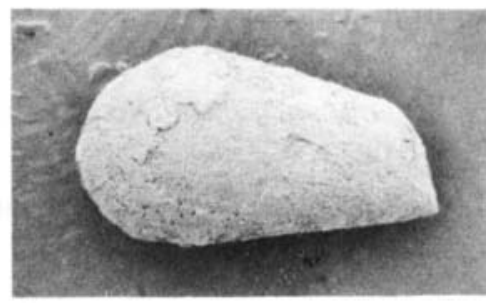

6

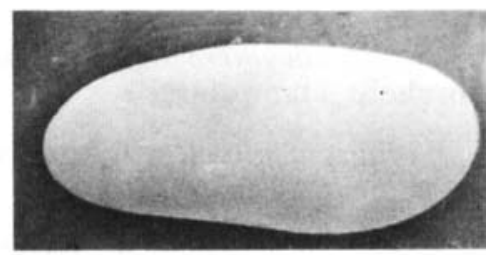

9

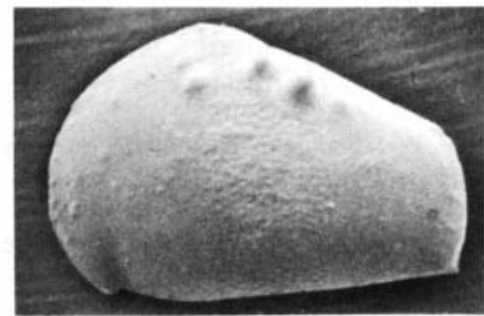

12

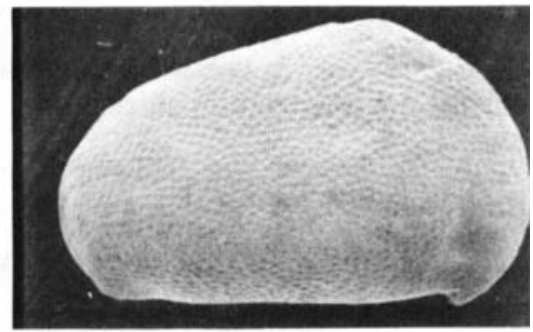

15

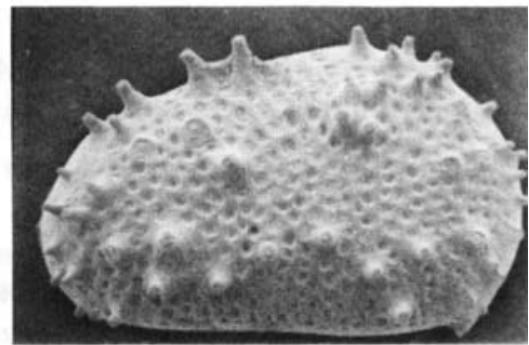

18 


\section{Explanation of Plate 12}

Fig. 1. Eoparacypris attenuata Anderson, Mik(M) 3277; holotype; length $0.8 \mathrm{~mm}$, height $0.315 \mathrm{~mm}$; Henfield No. 1 Borehole, Sussex.

Fig. 2. Eoparacypris surriensis Anderson, Mik(M) 3284; holotype; length $1.32 \mathrm{~mm}$, height $0.62 \mathrm{~mm}$; Warlingham Borehole, Surrey.

Fig. 3. Eoparacypris parallela (Neale), Mik(M) 3283; length 0.88 mm, height 0.385 mm; Chilcomb Down Borehole, Hampshire.

p. 35

Fig. 4. Eoparacypris edmundsi sp. nov., Mik(M) 3279; holotype; length $0.37 \mathrm{~mm}$, height $0.185 \mathrm{~mm}$; Warlingham Borehole, Surrey.

Fig. 5. Orthonotacythere inversa (Cornuel), Mik(M) 2412 ; length $0.5 \mathrm{~mm}$, height $0.275 \mathrm{~mm}$; Atherfield, Isle of Wight.

p. 36

Fig. 6. Orthonotacythere diglypta Triebel, female, Mik(M) 3271 ; length $0.61 \mathrm{~mm}$, height $0.325 \mathrm{~mm}$; Chilcomb Down Borehole, Hampshire.

p. 36

Fig. 7. Wolburgia polyphema Anderson, Mik(M) 2488; holotype; length $0.46 \mathrm{~mm}$, height $0.27 \mathrm{~mm}$; Mountfield No. 4 Borehole, Sussex.

Fig. 8. Stenestroemia decipiens (Anderson), Mik(M) 735; length $0.47 \mathrm{~mm}$, height $0.25 \mathrm{~mm}$; Town Gardens Quarry, Swindon, Wiltshire.

Fig. 9. Wolburgia tavola Anderson, Mik(M) 2487; holotype; length $0.41 \mathrm{~mm}$, height $0.215 \mathrm{~mm}$; Chilcomb Down Borehole, Hampshire.

Fig. 10. Wolburgia atherfieldensis Anderson, Mik(M) 673; holotype; length $0.29 \mathrm{~mm}$, height $0.17 \mathrm{~mm}$; Atherfield, Isle of Wight.

p. 38

Fig. 11. Eoparacypris edwardi Anderson, Mik(M) 3280; holotype; length $0.42 \mathrm{~mm}$, height $0.265 \mathrm{~mm}$; Warlingham Borehole, Surrey.

p. 35

Fig. 12. Fabanella dimorpha Anderson, Mik(M) 3214; holotype; length 1.09 mm, height 0.62 mm; Kingsclere No. 1 Borehole, Hampshire.

Fig. 13. Stenestroemia cressida Anderson, Mik(M) 2402; holotype; length $0.555 \mathrm{~mm}$, height $0.29 \mathrm{~mm}$; Kingsclere No. 1 Borehole, Hampshire.

p. 37

Fig. 14. Klieana thoracina Anderson, Mik(M) 3286; holotype; length $0.46 \mathrm{~mm}$, height $0.28 \mathrm{~mm}$; Mountfield No. 3 Borehole, Sussex.

Fig. 15. Stillina arkelli Anderson, Mik(M) 3267; holotype; length $0 \cdot 765 \mathrm{~mm}$, height $0.39 \mathrm{~mm}$; Warlingham Borehole, Surrey.

Fig. 16. Palaeocytheridea pellucida Anderson, Mik(M) 526; lectotype; length $0.94 \mathrm{~mm}$, height $0.60 \mathrm{~mm}$; Henfield No. 1 Borehole, Sussex.

Fig. 17. Scabriculocypris acanthoides Anderson, Mik(M) 728; holotype; length $0.68 \mathrm{~mm}$, height $0.44 \mathrm{~mm}$; Town Gardens Quarry, Swindon, Wiltshire.

Fig. 18. Scabriculocypris cerastes Anderson, Mik(M) 729; holotype; length $0.68 \mathrm{~mm}$, height $0.43 \mathrm{~mm}$; Town Gardens Quarry, Swindon, Wiltshire.

Fig. 19. Cypridea dolabrata kingsclerensis Anderson, Mik (M) 2125 ; holotype; length $1 \cdot 10 \mathrm{~mm}$, height $0 \cdot 78 \mathrm{~mm}$ : Kingsclere No. 1 Borehole, Hampshire.

p. 27

Fig. 20. Eocytheridea cf. oleroni (Donze), Mik (M) 3307, length $0.57 \mathrm{~mm}$, height $0.33 \mathrm{~mm}$; Warren House Farm, Stewkley, Buckinghamshire.

p. 34

Fig. 21. Orthonotacythere auricula Martin, Mik (M) 3269, length $0.61 \mathrm{~mm}$, height $0.33 \mathrm{~mm}$; Warlingham Borehole, Surrey. 


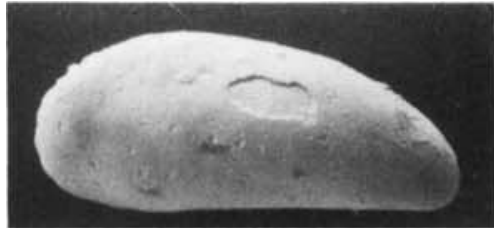

1

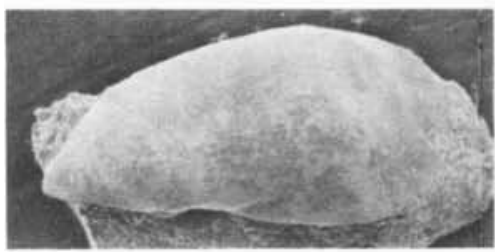

4

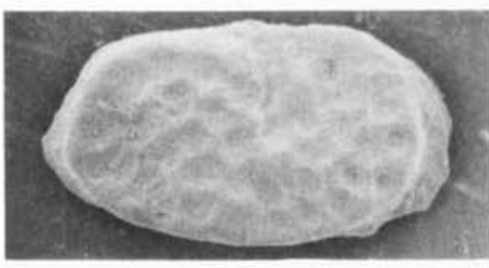

7

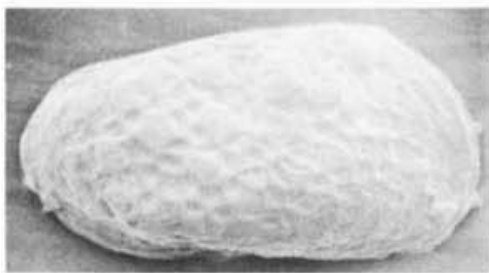

10

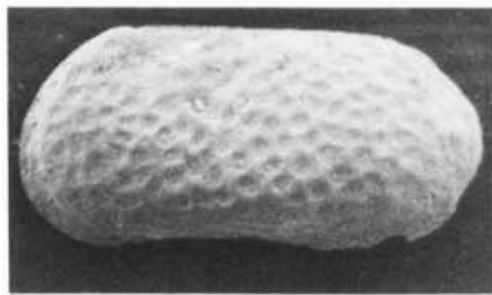

13

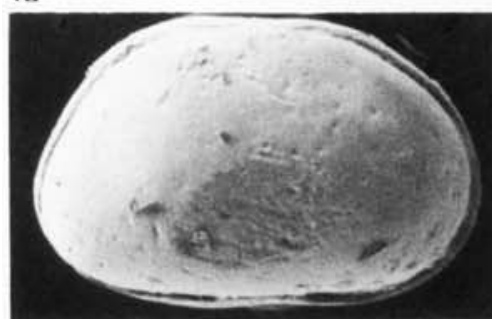

16

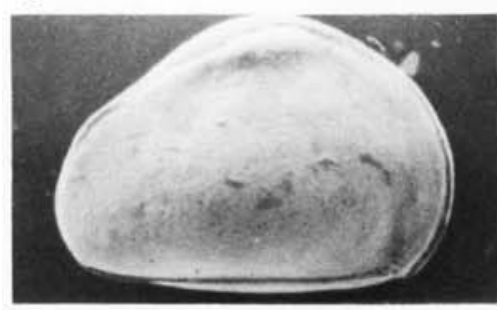

19

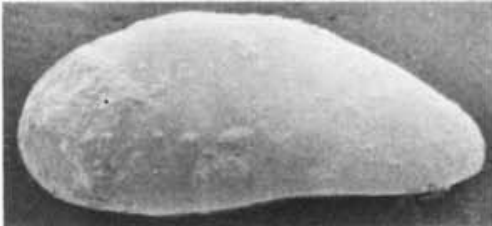

2

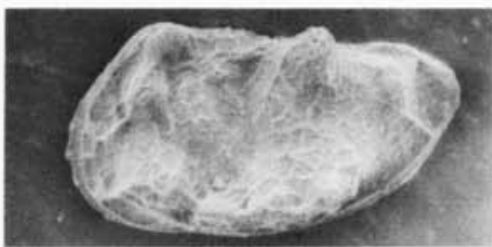

5
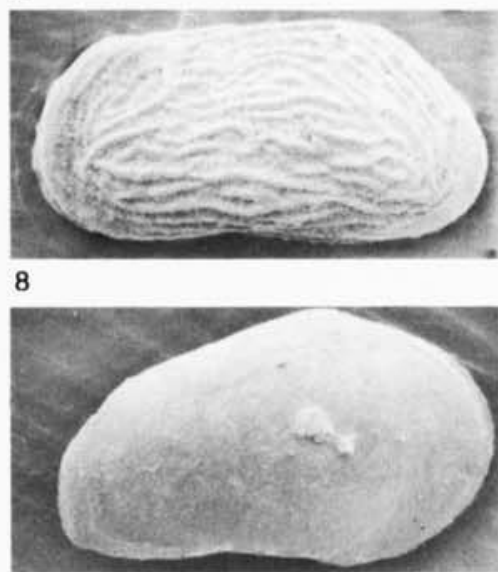

11

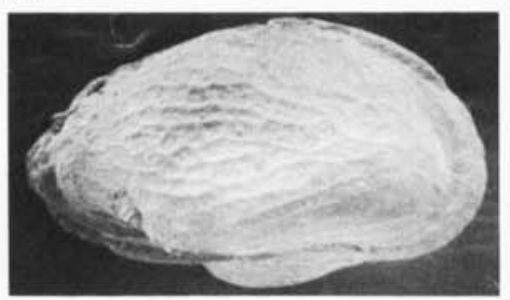

14

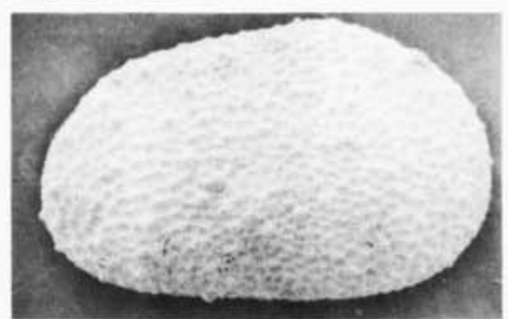

17

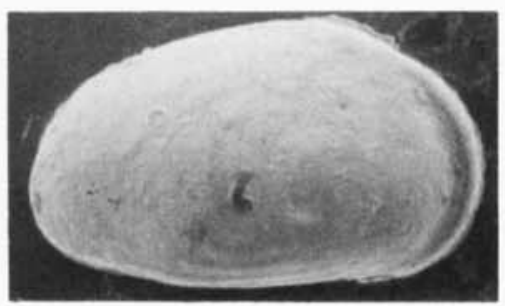

20

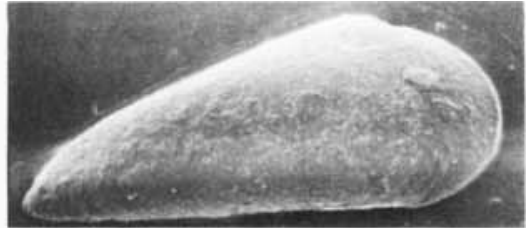

3

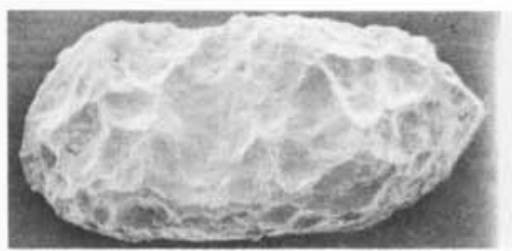

6

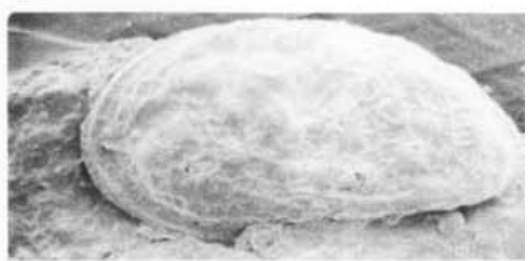

9

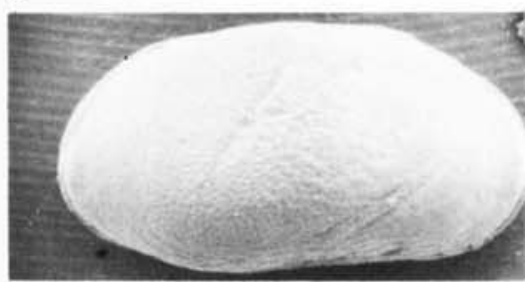

12

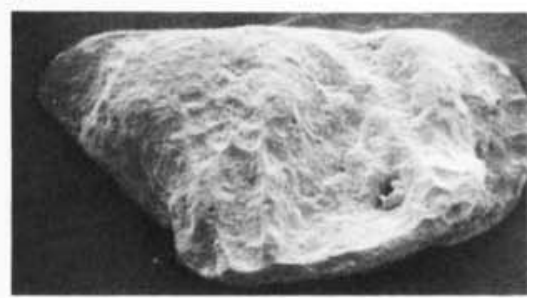

15

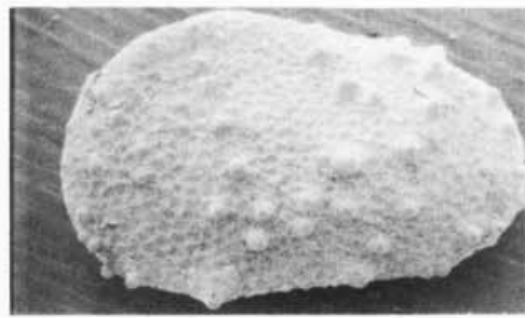

18

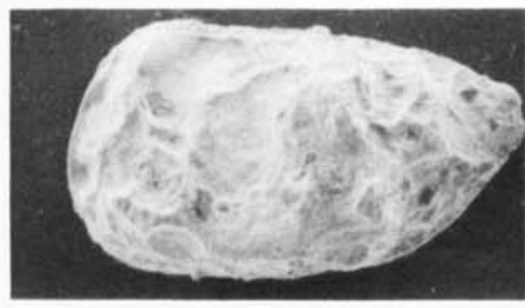

21 